\title{
Can International LETFs Deliver Their Promised Exposure to Foreign Markets?
}

\author{
Hongfei Tang \\ Stillman School of Business \\ Seton Hall University \\ South Orange, NJ 07079, USA
}

Tel: (973) 761-9151; Fax: (973) 761-9217

Email: hongfei.tang@shu.edu

Xiaoqing Eleanor $\mathrm{Xu}^{*}$

Stillman School of Business

Seton Hall University

South Orange, NJ 07079, USA

Tel: (973) 761-9209; Fax: (973) 761-9217

Email: xuxe@shu.edu

\author{
Zihui Yang \\ Lingnan (University) College \\ Sun Yat-sen University \\ Guangzhou, P.R. China
}

Tel: (86)20-84110625; Fax: (86)20-84114823

Email: yzh2016@gmail.com

This version: January 2014

* Corresponding author. 


\title{
Can International LETFs Deliver Their Promised Exposure to Foreign Markets?
}

\begin{abstract}
This study examines the tracking performance of U.S.-traded International Leveraged Exchanged-traded Funds (ILETFs) that track the following markets: Brazil, China, Europe, Japan, and Mexico. We find that the beta and returns of these ILETFs can deviate dramatically from their naïve expected counterparts. We further develop a comprehensive framework that decomposes an ILETF's return deviation into misperception-related components and tracking error-related components. Our results suggest that daily investors in ILETFs should be mindful of their under-exposure to the foreign market and over-exposure to the U.S. market, while longer-term investors should pay special attention to the negative compounding deviation during volatile markets.
\end{abstract}

Keywords: Leveraged ETFs; International Stock Markets; Price Discovery; Compounding Effect; Tracking Error; Market Efficiency

JEL Classifications: G11, G14, G15 


\section{Can International LETFs Deliver Their Promised Exposure to Foreign Markets?}

\section{Introduction}

The creation of International Leveraged Exchange-Traded Funds (ILETFs), ${ }^{1}$ U.S.-traded funds that track an underlying foreign market index, has brought investors the hope to adjust their exposure to international stock markets using these transparent and leveraged products. ${ }^{2} \mathrm{~A}$ typical ILETF states its investment objective as a constant multiple times the daily return of underlying foreign index. ${ }^{3}$ This investment objective gives people the impression that an ILETF can deliver a constant multiple of underlying index return when investors hold it in their portfolio. How valid is this impression? In this paper, we try to address this question in details.

In particular, we examine the return and tracking performance of five families of U.S.traded ILETFs tracking countries/regions ${ }^{4}$ such as Brazil, China, Europe, Japan, and Mexico, respectively, from their inception date to May of 2012. We start with the investigation of these ILETFs' exposure to their underlying indices using single-index beta estimation and find that ILETFs are significantly under-exposed to their underlying index for China and Japan, which have no overlapping trading hours with the U.S. For example, the $(-2 x)$ and $(2 x)$ Japan fund's exposure to its underlying index is as small as of $-63 \%$ and $115 \%$, which is substantially different from the promised $-200 \%$ and $200 \%$, respectively. For Brazil and Mexico, which have overlapping trading hours with the U.S., there is also a slight under-exposure, showing $-188 \%$

\footnotetext{
${ }^{1}$ See Appendix A for detailed definitions of terms and variables used in this paper.

${ }^{2}$ Previous literature has long documented the importance of international markets in portfolio risk diversification (see Levy and Samat (1970), Solnik (1974), Jorion (1989), Goetzmann, Li, and Geert (2005), and Miffre (2007)).

${ }^{3}$ For example, prospectus of ProShares UltraShort MSCI Japan fund (symbol: EWV) states its investment objective as "The Fund seeks daily investment results, before fees and expenses, that correspond to twice the inverse ( $-2 \mathrm{x})$ of the daily performance of the [MSCI Japan] index."
} 
and $-175 \%$ for the $(-2 \mathrm{x})$ Brazil and Mexico funds, respectively. Interestingly, ILETFs for Europe appear to be over-exposed to their underlying index, with $-227 \%$ and $223 \%$ for $(-2 x)$ and $(2 x)$ funds, respectively. ILETF market returns also deviate from their naïve expected counterparts. For example, daily return deviation of (-2x) Europe fund averages -9.5 basis points.

To identify the underlying mechanisms that drive the deviation of market returns from their naïve expected counterparts, we expand the Tang and Xu (2013) LETF return deviation decomposition framework to propose a five-component decomposition of this return deviation: currency, discovery, compounding, NAV, and inefficiency deviations. The currency deviation is calculated as the naive expected return based on foreign index denoted in U.S. Dollar (USD) less its counterpart in foreign currency (if available). This currency deviation reflects foreign exchange rate risk. For example, during our sample period, Japan experiences an appreciation of its currency and consequently bull (bear) double Japan LETFs experience positive (negative) currency deviation averaging $6.2(-6.4)$ basis points per day. In contrast, bull (bear) double Europe LETFs experience negative (positive) currency deviation averaging -1.6 (2.1) basis points. China LETFs only experience little currency deviation because the Hong Kong Dollar is (HKD) pegged to the USD. Brazil and Mexico funds don't have any currency deviation because their underlying indices are denoted in USD.

We find that the regular (1x) ETF is the actual benchmark used by international LETFs and consequently the deviation of the expected return based on regular (1x) ETF from that based on the USD-denoted underlying index is part of naïve investors' mis-perception. ${ }^{5}$ Because this deviation reflects the price discovery effect of new information that is reflected in the (1x) fund,

\footnotetext{
${ }^{4}$ For brevity, we will refer to these "countries/regions" as "countries" for the rest of the paper.

${ }^{5}$ The regular ETFs are also referred to as unlevered ETFs or $(1 \mathrm{x})$ ETFs.
} 
it is referred to as the discovery deviation. The information is new because these international ETFs are traded in the U.S. market when foreign markets may not be open. On a daily basis, the underlying index return, S\&P 500 index return, and lagged valuation premium of the (1x) fund can explain majority of the variation in the discovery deviation.

The significant coefficients on the underlying index suggest that the mechanism behind the overall under-exposure is largely explained by this discovery effect. The coefficients on S\&P 500 index return, registering $-229 \%,-168 \%,-114 \%,-77 \%$ and $-164 \%$ for the $(-2 x)$ China, Japan, Brazil, Mexico, and Europe funds, respectively, show that these funds are highly exposed to the U.S. market. In addition, the larger magnitude of non-overlapping markets relative to the overlapping markets suggests a structural difference between the two groups. The significance on the lagged valuation premium of $(1 \mathrm{x})$ fund reflects a partial correction of previous trading day's mis-valuation of this regular fund.

To measure the ability of ILETF management to achieve its target, we define NAV deviation as the ILETF's NAV return less its naïve expected return based on (1x) fund return. On a daily basis, this deviation component accounts for a large proportion of the total return deviation for most ILETFs. Lagged NAV deviation is negatively associated with this deviation for both bull and bear ILETFs, consistent with the existence of some inaccuracy and a subsequent correction in evaluating the NAV of an ILETF. Moving to multiple holding days, this deviation component tends to accumulate over time.

Aside from these three components, on daily basis, actual market return of these funds can also deviate from the NAV return due to market inefficiency and/or trading frictions. This deviation component is referred to as inefficiency deviation in our framework. This inefficiency deviation corrects lagged valuation premium of the ILETF, with a coefficient of -0.97 and -0.94 
for the $(-2 x)$ and $(2 x)$ China funds, respectively, -0.90 for both the (-2x) and (2x) Japan funds, and similar magnitudes for most other funds. In addition, this inefficiency deviation also helps to explain the under-exposure of ILETFs to their underlying indices. Consistent with the creation/redemption feature of these funds, the inefficiency deviation generally does not accumulate over multiple holding days. As for the daily total return deviation, they are mainly driven by the lagged ILETF valuation premium, the lagged valuation premium of its corresponding regular $(1 \mathrm{x}) \mathrm{ETF}$, the lagged total deviation of ILETF, the underlying index return, and the S\&P 500 index return. The impact of these drivers is generally different between countries with and those without overlapping trading hours, suggesting a structural difference between them.

When holding an ILETF for multiple trading days, an investor will face an additional return deviation component called compounding deviation. The compounding deviation is the difference between the daily leveraged benchmark return compounded over time and the leveraged multiple times the cumulative benchmark return. This deviation component is a part of investors' misperception. In our sample, this deviation component is sizable, registering $-3.06 \%$ and $-0.97 \%$ during a 21-day holding period for the $(-2 \mathrm{x})$ China and Japan funds, respectively. What drives this deviation is the daily rebalancing of an LEFT's exposure to its underlying index in order to achieve the constant leverage for each trading day. Our results show that daily return variance and squared cumulative return can explain more than $96 \%$ of the variation of this component. The negative compounding deviation of the $(-2 x)$ China and Japan funds can be explained by the high volatility of these two foreign markets during the recent financial crisis.

By comparing different length of holding periods ranging from one to 21 trading days, we observe that the S\&P 500 index has a large impact on the daily returns of ILETFs and this 
impact decays as the holding period gets longer. This pattern is more evident for countries without overlapping trading hours (such as China and Japan) than those with (such as Mexico and Brazil). For example, the correlation between the $(-2 \mathrm{x})$ China fund return and the S\&P 500 index return moves from -0.83 for daily observations to -0.56 for 21 -day observations. In contrast, the return correlation between the ILETFs and their broad-based foreign home market indices gets stronger as the holding period lengthens, especially for countries with overlapping trading hours. For example, the return correlation between the $(-2 x)$ China fund and the Shanghai Composite Index improves from -0.26 for daily periods to -0.51 for 21 -day holding periods.

Our paper is interesting to both academic researchers and practitioners in investments. From an academic perspective, our findings provide additional evidence toward the location bias in the behavioral finance literature (see Bodurtha, Kim, and Lee (1995), Coval and Moskowitz (1999), Froot and Dabora (1999), Hau (2001), Tse and Martinez (2007), and Guitierrez, Martinez and Tse (2009)). In particular, our findings show that U.S.-traded ILETFs overreact to U.S. market sentiments on a daily horizon and this overreaction is partially corrected over the time, especially for countries with non-overlapping trading hours. In addition, our comprehensive return deviation decomposition also provides a new framework for future research to examine the sources of return deviation for international leveraged exchange-traded products. For the general investment community, this paper shows that daily investors in ILETFs should be mindful of their underexposure to the foreign markets and unintended exposure to the U.S. market index. While this discovery deviation is corrected over time, longer-term investors should pay special attention to the compounding deviation especially in highly volatile markets. 
The rest of this paper is organized as follows. Section 2 describes the data and presents the methodology. Section 3 presents our main empirical results. Finally, Section 4 concludes the paper.

\section{Data Description and Methodology}

The data for this study are obtained from Bloomberg. Appendix B describes our sample of regular and leveraged ETFs in details, including the daily target multiple, underlying index, inception date, expense ratio, total assets under management as of May of 2012, and the average number of holding days during the sample period. As shown in Appendix B, our sample includes LETFs tracking five foreign country/region indices: the FTSE China 25 Index (XINOU), MSCI Japan Index (MXJP), MSCI Brazil Index (MXBR), MSCI Mexico Investable Market Index (MZMXI), and MSCI Europe Index (MXEU). We include both the double (2x) and inverse double $(-2 x)$ funds. In addition, the regular (1x) ETFs tracking these indices are also included as there is evidence that they are the actual benchmark used by ILETF fund providers.

The first batch of ILETFs include the inverse double (-2x) funds for China and Japan in November of 2007. The second batch was not issued until June of 2009. The expense ratio of these ILETFs is $0.95 \%$, higher than that of their corresponding regular ETFs, mainly due to the daily rebalancing needs. The total assets under management (AUM) of the ILETFs are much less than that of the regular ETFs. For example, for China, the inverse double, double, and regular funds have an AUM of 205, 25, and 5255 million USD, respectively. For Brazil, the inverse double, double and regular funds have an AUM of 19, 9, and 7195 million USD, respectively.

We collect daily data on the price, dividend, NAV, bid-ask spread, trading volume, and number of outstanding shares on these regular and leveraged ETFs, along with the total return on 
the underlying foreign market indices and the foreign broad-market indices from Bloomberg. When calculating the returns for ETFs and their underlying indices, we always include the effects of both price changes and dividend payments. ${ }^{6}$ Our period of study starts from the LETF's inception date and ends on May 31, 2012. The number of observations ranges from 526 for the (2x) Europe fund to 1148 for the (-2x) China fund.

LETFs are designed to achieve a leveraged multiple of the underlying index return over a trading day. Table 1 estimates the daily beta of international ETFs with respect to their underlying foreign market index using the single index model. As shown in Panel A, for markets without overlapping trading hours with the U.S., international ETFs are significantly underexposed to their underlying indices relative to their stated product multiples. For China, the daily beta of the regular ETF is 0.6 , which is significantly less than the product multiple of 1 . Similarly, the beta of the $(-2 x)$ fund is -1.14 and that of the $(2 x)$ fund is 1.15 . For Japan, the beta is 0.31 for regular ETF, -0.63 for $(-2 x)$, and 0.67 for $(2 x)$ funds. These findings suggest that daily investors should be mindful of the actual exposure of these international ETFs to underlying foreign market indices. For example, on a day when the underlying Japanese index experiences a $-10 \%$ return, a (-2x) Japan fund holder may expect his fund to achieve a return of $20 \%$. However, the actual fund return may only be around $6.3 \%$.

In contrast, the betas of ETFs for markets with overlapping trading hours are much closer to their product multiples than the case for markets with overlapping trading hours. As shown in Panel B, for Brazil, the beta is -1.88 for the $(-2 x)$ fund and 1.84 for the $(2 \mathrm{x})$ fund. Similarly, for Mexico, the beta is -1.75 for the $(-2 x)$ fund and 1.11 for the $(2 x)$ fund. For Europe, the beta is -

\footnotetext{
${ }^{6}$ Unlike the domestic ETF case, there are some calendar days when a foreign market is open while the U.S. market is closed, and vice versa. To accommodate the calendar days when the foreign market is open but not the U.S., we accumulate the foreign index return to the next trading day. To accommodate the calendar days when the U.S. market is open but not the foreign market, we give the foreign index a return of zero for those days.
} 
2.27 for the $(-2 \mathrm{x})$ fund and 2.23 for the $(2 \mathrm{x})$ fund. As shown in Panel $\mathrm{C}$, the difference in index tracking for markets with and without overlapping trading hours is highly significant. This difference is likely due to the lack of arbitrage opportunities for markets without overlapping trading hours, as an effective arbitrage typically involves simultaneous transactions in both the U.S. market and foreign markets.

These findings are consistent with the interpretation that U.S. investors have significant behavioral bias. In particular, U.S. investors evaluate foreign indices based on the U.S. market sentiments, especially when foreign markets are closed. These findings have a direct implication for the investors: ILETFs actually offer very limited exposure to foreign market indices on a daily basis, especially for markets without overlapping trading hours. ${ }^{7}$ In the fact sheet and prospectus of a typical ILETF, the fund sponsor states that its objective is to achieve a constant multiple (before fees and expenses) of the daily performance of its underlying index. ${ }^{8}$ Based on this statement, a naïve ILETF holder would expect to achieve the product multiple times its underlying index return. We therefore define the naïve expected return of an ILETF as the fund's product multiple times the return on its underlying foreign market index.

\footnotetext{
${ }^{7}$ Although these ILETFs are under-exposed to their underlying foreign market indices, when using the daily return of (1x) fund as benchmark, the actual daily return multiple of these ILETFs is much closer to their product multiple. For example, the beta for (-2x) Japan fund is -0.63 , which is close to inverse double of the beta of the regular Japan ETF (0.31). This finding suggests that the actual benchmark used by ILETFs is their corresponding regular ETFs on a daily basis. To confirm this conjecture, we regress the NAV return of ILETFs on the actual market return of regular ETFs and find consistent results (available upon request). Ideally, we would like to have the NAV return of regular ETFs as benchmark. However, the NAV values of regular ETFs are based on the close prices of foreign markets and these values are quite different from the market price at the close of U. S. market.

${ }^{8}$ For example, the first paragraph of ProShares UltraShort MSCI Japan fund fact sheet states its objective as "ProShares UltraShort MSCI Japan seeks daily investment results, before fees and expenses, that correspond to twice the inverse $(-2 x)$ of the daily performance of the MSCI Japan Index".
} 
So far, our results suggest that the market return of an ILETF can deviate substantially from its naïve expected return. ${ }^{9}$ Why do they deviate from each other? There are a couple of potential explanations: First, some underlying indices are denoted in foreign currencies and our sample ILETFs are denoted in USD, and consequently, ILETF returns can deviate from underlying indices returns due to the change in foreign exchange rate. To examine the impact of foreign exchange rate, we therefore define a naïve expected return based on the underlying index denoted in foreign currency (if available) and a naïve expected return based on the underlying index denoted in U.S. dollars. The difference between these two (the naïve expected return based on underlying index in foreign currency less the counterpart in USD) as the currency deviation of an ILETF.

Second, an ILETF is traded in the U.S. market, while securities in the underlying index are traded in a foreign market. When the U.S. market is open, some foreign markets are closed. Therefore the market price of the ILETF may discover new information not reflected in the previous closing price from the foreign market. Even when both markets are open, an ILETF can be affected by the U.S. market sentiments or discover new information inferred from the U.S. market. ${ }^{10}$ As previously mentioned, our findings suggest that these ILETFs are actually benchmarked to their regular ETFs. To examine this price discovery role, we define the naïve expected return based on the return of the corresponding U.S.-traded regular ETF as the product multiple times the return of the $(1 \mathrm{x})$ fund. On each trading day, this return is the actual target return of the ILETF.

\footnotetext{
${ }^{9}$ Consistent with our findings, Engle and Sarkar (2006) also document that international ETFs have larger and more persistent premiums (discounts) than domestic ETFs.

${ }^{10}$ As documented in Chan, Menkveld, and Yang (2008), information asymmetry can also lead to the price difference between China's local A share and foreign B share markets.
} 
Third, to achieve a constant leverage over each trading day, there is a financing cost to lever the exposure to the underlying index. In addition, the fund sponsor of an ILETF has to rebalance the exposure to its underlying index at the end of each trading day. Following Tang and $\mathrm{Xu}$ (2013), we define the NAV return of an ILETF as the return of NAV plus the dividend yield and define the NAV return deviation ${ }^{11}$ as the NAV return less the target return. This deviation component reflects fund provider's ability to achieve its target. Tang and $\mathrm{Xu}$ (2013) argue that the swap-related LIBOR interest payment (receipt) will lead to negative (positive) NAV deviation for bull (bear) LETFs.

Fourth, the actual market price of an ILETF can deviate from its NAV due to market frictions and illiquidity. As in Tang and Xu (2013), we define an inefficiency deviation as the LETF actual market return less the NAV return. This deviation reflects market inefficiency or trading frictions.

\section{Empirical Results}

\subsection{Daily Return Deviations}

To examine how market returns of these ILETFs deviate from the naïve expected return based on their underlying indices, we tabulate these returns and return deviations in Table 2. As shown in the table, for the $(-2 \mathrm{x})$ China fund, the average naïve expected daily return in foreign currency is 2.5 basis points. However, the average actual market total daily return is -4.6 basis points. Therefore, the total deviation is -7.1 basis points $(-4.6-2.5=-7.1)$. At the same time, these returns and the deviations are highly volatile. For example, the market return of this fund

\footnotetext{
${ }^{11}$ In this paper, we refer to NAV return deviation and NAV deviation interchangeably.
} 
has a daily standard deviation of $5.9 \%$, which is partly due to the fact that our sample period of this fund includes the recent financial crisis of 2008. The standard deviation of daily total deviation is $5.5 \%$, which suggests that the market return of this fund can substantially deviate from its naïve expected return based on the underlying foreign market index in foreign currency.

When we break the total deviation into four components as described above, the average daily deviation is $-0.04,-2.5,-1.9$, and -2.7 basis points for the currency, discovery, NAV, and inefficiency deviation components respectively. The small currency deviation of this fund is due to the fact that the foreign currency of underlying index (Hong Kong dollar) is pegged to U.S. dollar and consequently the index return in foreign currency and that in USD are very close. The discovery, NAV, and inefficiency deviation, accounts for 35\% $[(-2.5) /(-4.6)=35 \%], 26 \%$, and $38 \%$ of total deviation respectively. In terms of variation, the discovery deviation has the largest standard deviation, $5.7 \%$ per day.

For the $(-2 \mathrm{x})$ Japan fund, the average naïve expected return based on the Japanese Yendenoted underlying index is 9.1 basis points. The actual daily market return is 1.7 basis points. Consequently, there is a daily average total return deviation of -7.4 basis points. The currency deviation accounts for the largest proportion, registering a daily average of -6.4 basis points. This negative currency deviation is consistent with the general currency appreciation trend of Japanese Yen during the sample period. The daily average discovery, NAV, and inefficiency deviations are $0.3,-0.3$, and -0.9 basis points, respectively. These two funds are the ones with the longest history in our sample, while all of the other funds are incepted after the financial crisis. The average total deviation is 0.2 basis points for the (2x) China fund, 4.6 for the (2x) Japan fund, -0.4 for the (-2x) Brazil fund, -0.6 for the (2x) Brazil fund, -4.6 for the (-2x) Mexico fund, 3.4 for the $(2 \mathrm{x})$ Mexico fund, -1.2 for the $(-2 \mathrm{x})$ Europe fund, and -1.3 for the $(2 \mathrm{x})$ Europe fund. The 
large deviation of the (2x) Japan fund is mainly due to the appreciation of its currency. The large deviation of Mexico funds may be related to their small fund size and lack of liquidity. In particular, the AUM is 1.5 and 2.3 million dollars for $(-2 \mathrm{x})$ and (2x) Mexico fund respectively. These AUMs are much smaller than those of other ILETFs. Even the size of Mexico regular (1x) ETF is much smaller than that of other countries. In addition, because the underlying indices for Brazil and Mexico are denoted in USD, there is no currency deviation for these funds.

What are the fundamental drivers for the discovery deviation? As mentioned, the discovery deviation is due to the difference between the regular ETF return and the underlying index return denoted in USD. There are a few potential drivers for this difference. First, since the ETFs are traded in U.S., the U.S. market sentiment might have an influence on the ETF returns (see Tse and Martinez (2007) and Gutierrez, Martinez, and Tse (2009)). We therefore include the S\&P 500 index return as an independent variable and predict a positive (negative) coefficient for bull (bear) funds. Furthermore, we expect this U.S. market influence to be stronger for countries without overlapping trading hours than for those with, as there is less information regarding underlying foreign indices during U.S. trading hours. Second, if the U.S. market sentiment drives international ETF returns, it may wash out the exposure to the underlying foreign index. As a result, we would observe an underexposure of an ILETF to its underlying index. We therefore include the underlying index return in USD as an independent variable. This argument predicts a negative (positive) coefficient for bull (bear) funds. Third, the (1x) ETF return may be different from its NAV return due to stale underlying index or market frictions. For example, if the market price of a regular ETF is different from its NAV value at the end of a trading day, we would expect an efficient market to correct the difference on the subsequent day. For this reason, we include the lagged valuation premium of the (1x) fund as an independent variable and predict a 
negative (positive) coefficient for bull (bear) funds. ${ }^{12}$ In addition, we also control for VIX, turnover of the $(1 \mathrm{x})$ fund, net fund flow of the $(1 \mathrm{x})$ fund, and daily change in the LIBOR rate.

As shown in Table 3 Panels A and B, consistent with our predictions, the SPX index return indeed plays a significant role in discovery deviations. The coefficient on the SPX index return is -2.2 for the $(-2 x)$ China fund, 1.8 for the $(2 x)$ China fund, -1.9 for the $(-2 x)$ Japan fund, and 1.5 for the (2x) Japan fund. These coefficients are highly significant both economically and statistically, showing that the U.S. market return plays a pivotal role in affecting the (1x) fund returns, which is the benchmark for ILETF returns. If a $(-2 \mathrm{x})$ fund were fully exposed to the SPX index, we would observe a coefficient of -2 for $(-2 x)$ funds and 2 for $(2 x)$ funds. These coefficients show that that $(1 \mathrm{x})$ fund is almost fully exposed to the U.S. market. In terms of Rsquared, SPX index return alone can explain $46 \%$ of the variation of discovery deviation for the $(-2 x)$ China fund, $42 \%$ for the $(2 x)$ China fund, $49 \%$ for the $(-2 x)$ Japan fund, and $39 \%$ for the (2x) Japan fund. These results show that the U.S. market sentiment plays a critical role in shaping the daily returns of international ETFs. This finding has important implications to the investment community as typical investors' intention to diversify into international markets using international ETFs may be negatively affected as these ETFs actually add more U.S. market risk into the portfolio.

As shown in Panel B, for markets with overlapping trading hours with the U.S., SPX index also has a significant impact on discovery deviation, although not as large as it has for markets without. The coefficient on the SPX index return is -0.41 for the $(-2 \mathrm{x})$ Brazil, 0.39 for the (2x) Brazil, -0.49 for the $(-2 x)$ Mexico, 0.47 for the $(2 x)$ Mexico, -0.75 for the $(-2 x)$ Europe,

\footnotetext{
${ }^{12}$ Ideally, we hope to calculate valuation premium using market value and NAV of (1x) fund evaluated at the same time. However, for $(1 \mathrm{x})$ fund, the NAV is estimated based on the index level at the close of foreign market, while the market price is based on the U.S. market close. There could be non-synchronous issue for some countries, such as China and Japan.
} 
and the 0.78 for the $(2 x)$ Europe. All these coefficients are different from 0 significantly. In terms of R-squared, the SPX index return explains a smaller portion of variation in discovery deviation for markets with overlapping hours than for those without. The difference between the two groups is confirmed by a formal test in Panel C, where there is a significant coefficient on the interaction term between the SPX index return and the no-overlapping indictor. The sign and magnitude of this coefficient show that the U.S. market sentiment plays a greater role for countries without overlapping trading hours than for those with.

As shown in the table, the underlying index return (in USD) is an important determinant of discovery deviation. For the $(-2 \mathrm{x})$ China fund, the coefficient on the underlying index return (in USD) is 0.6 , showing that there is an under-exposure of this fund to its underlying index. In particular, the target exposure is -2 , while the actual exposure is $-2+0.6=-1.4$. This coefficient has a value of $0.81,0.67,0.35$, and 0.86 for the (-2x) Japan, Brazil, Mexico, and Europe funds, respectively. On the other hand, this coefficient has a value of $-0.56,-0.79,-0.7,-0.38$, and -0.73 for the (2x) China, Japan, Brazil, Mexico, and Europe funds, respectively. These coefficients show that ILETFs are significantly under-exposed to their underlying foreign market indices. In other words, ILETFs actually carry less foreign market risk than their product multiples predict. This finding also implies ILETF investors may not get the promised exposure to the foreign index as their naïve expectations.

Table 3 also shows the important role of the lagged valuation premium of $(1 \mathrm{x})$ fund to the discovery deviation of an ILETF. The coefficient on the lagged valuation premium is $1.3,1.2$, 0.4, 1.8, and 0.7 for the inverse double China, Japan, Brazil, Mexico, and Europe funds, respectively. The coefficient on the lagged valuation premium is $-1.2,-1.1,-0.3,-1.8$, and -2.3 for bull double China, Japan, Brazil, Mexico, and Europe funds, respectively. These coefficients 
show that regular ETFs partially correct/reverse the valuation premium from the previous trading day.

In summary, empirical results from Table 3 show that the SPX index return, underlying index return (in USD), and lagged valuation premium are three key determinants of discovery deviation. These three variables together explain more than $85 \%$ of the variation in discovery deviation for countries without overlapping trading hours. These variables remain significant after adding a set of volatility, liquidity, and interest rate control variables. The coefficients show that ILETFs carries significant U.S. market risk and, at the same time, are under-exposed to their underlying foreign market indices. As mentioned, our analysis shows that ILETFs' actual benchmark is their corresponding regular $(1 \mathrm{x})$ ETFs and therefore the discovery deviation is unavoidable to ILETF returns.

In addition to the discovery deviation, the NAV return of an ILETF may be different from the return predicted by the corresponding regular (1x) ETF. What are the determinants of this difference? First, as explained by Tang and Xu (2013), the holding period LIBOR interest should be driving this NAV deviation if an ILETF sponsor uses swap contracts or other derivatives to deliver leveraged exposure. For simplicity, without resort to financial derivatives, to achieve twice the exposure to the underlying index, an ILETF fund needs to borrow extra fund to invest in the underlying index. To catch this borrowing cost, we include the holding-period LIBOR interest as an independent variable. Since the LIBOR interest over a period is calculated following the actual calendar days over 360 days convention, we calculate the LIBOR interest earned over one trading day using the actual number of calendar days between the previous trading day and the current trading day, divided by 360, and then multiplied by the LIBOR rate 
from the previous trading day. ${ }^{13}$ The borrowing cost predicts a negative coefficient on the holding period LIBOR interest for bull ILETFs. Vice versa, this argument predicts a positive coefficient for inverse ILETFs. Second, fund sponsors may not accurately evaluate ILETFs' net asset value. This inaccuracy and a correction on the subsequent trading day can lead to a mean reversion in the NAV deviation. We therefore include lagged NAV deviation as another independent variable. The mean reversion argument predicts a negative coefficient. Third, for an ILETF to achieve its target multiple, the fund sponsor needs to rebalance the fund's exposure to the underlying index at the end of each day. This rebalancing is challenging because the fund sponsor needs to know the benchmark return for the entire trading day to be able to achieve a correct rebalance, but the rebalance itself needs to be done before the market close. To reflect the potential imperfect exposure to the (1x) fund, we also include the (1x) fund return as an independent variable.

As shown in Table 4, there is a negative coefficient on the lagged NAV deviation, suggesting a mean-reversion process in the NAV deviation. For countries without overlapping trading hours, there is a consistent mis-exposure to the $(1 \mathrm{x})$ funds. There is less mis-exposure for countries with overlapping hours. The coefficients on the holding-period LIBOR interest are generally not statistically significant, maybe due to the immature nature of financial derivatives on these foreign country indices. Most of the control variables are not significant either.

Lastly, the market return of an ILETF can be different from its NAV return. ${ }^{14}$ If the market price of an ILETF differs from its NAV at the end of previous trading day, the creation

\footnotetext{
${ }^{13}$ We carry out an augmented Dickey-Fuller test on this holding-period LIBOR interest and reject the unit root hypothesis in this variable.

${ }^{14}$ Our results suggest that the NAV of an ILETF is based on the market value of its corresponding regular (1x) ETF at U.S. market close. This valuation method is different from the assessment of NAV for (1x) fund, as the NAV of
} 
and redemption feature will bring the market price back to the NAV. We therefore include the LETF's lagged valuation premium as an independent variable and predict a coefficient of -1 in an efficient market. In addition, the stale price of ILETF relative to its benchmark of (1x) fund as well as the ILETF holders' short-term trading behavior can lead to an observed under-exposure. Consequently, we include (1x) fund return as an independent variable.

As shown in Table 5, there is a significant negative coefficient on the lagged valuation premium for all ILETFs. This coefficient is $-1.0,-0.96,-0.94,-0.93$ for the $(-2 \mathrm{x})$ China, $(2 \mathrm{x})$ China, (-2x) Japan, and (2x) Japan funds, respectively. All these coefficients are not statistically different from the predicted value of -1 . For countries with overlapping trading hours, the coefficients are also negative and significant. The coefficients for Mexico funds are smaller in magnitude, which could be due to their small fund size and thin trading volume. The coefficients on the $(1 \mathrm{x})$ fund return are mostly significant showing an observed under-exposure to ILETFs' actual benchmark. These coefficients generally stay significant after adding a set of control variables.

Based on the above analysis on the deviation components, we include the SPX index return, underlying index return, lagged valuation premium of LETF, lagged valuation premium of $(1 \mathrm{x})$ fund, and lagged total deviation of LETF as independent variables in the total deviation determinants analysis. As shown in Table 6, the coefficients are largely consistent with our deviation component analysis. First, there is a significant negative coefficient on the SPX index return for bear ILETFs and a positive coefficient for bull ILETFs. This finding is consistent with our discovery deviation analysis and shows that these ILETFs are significantly exposed to the U.S. market risk. Second, there is a significant positive coefficient on the underlying index return component assets in foreign stock markets. 
for bear ILETFs and a negative coefficient for bull ILETFs. This finding is also consistent with the discovery deviation analysis and shows that these ILETFs are significantly under-exposed to their underlying index. Third, consistent with our inefficiency deviation analysis, there is a negative coefficient on the lagged valuation premium of LETF, showing a correction of misevaluation of market price relative to an ILETF's NAV. Fourth, the coefficients on the lagged valuation premium of $(1 \mathrm{x})$ fund are positive for bear ILETFs and negative for bull ILETFs. These results are also consistent with our discovery deviation analysis. Lastly, most ILETFs have a negative coefficient on lagged total deviation of LETF, suggesting a mean-reverting process in the total daily return deviation. Our findings are important to the practitioners. For example, for the $(-2 \mathrm{x})$ China fund, the coefficient on the SPX index return is -2.2 , which means that the daily holder of this fund is bearing more U.S. market risk than the (-2x) SPX fund. In the meantime, the coefficient on the underlying index return is 0.65 , showing that the actual leverage relative to underlying index is only -1.35 . Therefore, the holders of this fund actually take a large U.S. market risk while only taking a relatively small foreign market risk, which may be unexpected to naïve investors. From this point of view, the ILETFs may only play a placebo role for investors who would like to gain foreign market exposure on a daily horizon.

As shown in Panel C, the influence of these independent variables is generally different between countries with overlapping trading hours and those without.

\subsection{Cumulative Return Deviations}

As explained in Cheng and Madhavan (2009), Avellaneda and Zhang (2010), as well as Tang and Xu (2013), if an investor holds an ILETF for multiple trading days, in addition to the four deviation components mentioned in the previous subsection, there is an additional deviation 
component due to the fact that the cumulative leveraged target return is different from the product between the product multiple and the cumulative target return. Following Tang and $\mathrm{Xu}$ (2013), we define this additional deviation as the compounding deviation. To clearly depict all five components of deviations for cumulative returns, Figure 1 illustrates them in detail. Since the currency and discovery deviations are due to the misperception of the ILETF's actual benchmark, while the compounding deviation is due to the misperception of the ILETF's daily compounding, we define the misperception-related deviation as the sum of currency, discovery, and compounding deviations. In contrast, the NAV and inefficiency deviations are due to the fact that market transaction price may not be able to achieve the target return of an ILETF and consequently, we define the tracking error-related deviation as sum of the NAV and inefficiency deviations.

Table 7 reports summary statistics of the cumulative total deviation and the five components on a rolling basis for each sample ILETF. To ease the concern of overlapping days between two contiguous observations, we report the Newey-West robust standard errors of these means. For the $(-2 x)$ China fund, the total deviation increases more than proportionally with the number of holding days. In particular, the average is $-7.4,-46.6$, and -348.6 basis points for the one-day, four-day, and 21-day total deviations, respectively. For a holding period with multiple days, the largest deviation component is the compounding deviation. For example, for 4-day periods, the compounding deviation is averaged -34 basis points, accounting for $73 \%$ of total deviation. For 21-day periods, the compounding deviation is -306.4 basis points, around for $88 \%$ of total deviation. The compounding deviation for other funds is also negative for 21-day periods. In addition, the compounding deviation is generally larger in magnitude for the $(-2 \mathrm{x})$ funds than 
the corresponding $(2 \mathrm{x})$ funds. What drives the compounding deviation? To address this question, we carry out a set of analysis in Table 8 using the framework from Tang and $\mathrm{Xu}$ (2013).

As shown in Table 8, the compounding deviation is negatively driven with the variance of the (1x) fund daily returns while positively driven by the square of cumulative (1x) fund return during the holding period. These two variables can explain almost all the variation in the compounding deviation. In addition, the coefficients are consistent across countries and are larger for the $(-2 x)$ funds than for the $(2 x)$ funds, reflecting the mathematical nature of this compounding deviation. These findings suggest that investors should avoid holding ILETFs for a long period when the market is highly volatile as characterized by high variance of the (1x) fund daily returns. On the other hand, when the market is smoothly trending (i.e. with low volatility and a large magnitude of cumulative return), the compounding deviation can be beneficial to fund holders.

In Table 9, we examine the factors that drive the cumulative total return deviations. As shown in the table, the cumulative SPX index return during the holding period is related to the total deviation, suggesting that these ILETFs actually carry a significant amount of U.S. market risk. As the number of holding days increases from 4 to 21, the effect of the SPX index generally decreases. Consistent with compounding deviation analysis, the variance of $(1 \mathrm{x})$ fund daily returns is generally negatively related to the total deviation of $(-2 x)$ funds and the squared cumulative $(1 \mathrm{x})$ fund return is generally positively related to the total deviation of $(-2 \mathrm{x})$ fund. In addition, the cumulative total deviation also bears a mean-reverting process. This mean-reversion feature is more significant for shorter holding periods than longer holding periods.

The previous empirical analysis has examined how well ILETFs track their stated underlying foreign market indices. However, since most investors hold ILETFs to 
enhance/decrease their exposure to the foreign stock markets, it is also relevant to ask how well does the performance of these ILETFs relative to that of the foreign broad market indices. To address this question, we examine the return correlation between ILETFs and their foreign broad market indices in Table 10. In particular, we use the Shanghai Composite Index (Bloomberg symbol: shcomp) to measure the foreign market return for China, Nikkei 225 Index (nky) for Japan, Bovespa Brasil Sao Paulo Stock Exchange Index (ibov) for Brazil, Mexican Bolsa Ipc Index (mexbol) for Mexico, and FTSEurofirst 300 Index (e300) for Europe. These broad market indices are not the exact underlying indices that ILETFs are tracking. As shown in the table, the daily correlation is low for countries without overlapping hours. This correlation is -0.26 and 0.29 for the (-2x) China and Japan funds, respectively. These low correlations raise the question as to what risk does these ILETFs carry, foreign market risk or U.S. market risk?

To answer this question, we also report the ILETFs' return correlation with both the foreign broad market index and the SPX index in the table. Interestingly, the correlation is -0.83 and -0.82 for the $(-2 \mathrm{x})$ China and Japan funds, respectively. These ILETFs' high correlation with the U.S. market and low correlation with the foreign market show that daily holders are exposed to the U.S. market rather than the foreign market. As the holding period lengthens from one day to 21 days, these ILETF returns are more closely related to foreign broad market returns. For the $(-2 x)$ China fund, the correlation is $-0.26,-0.41$, and -0.51 for the one-day, four-day, and 21-day holding periods, respectively. Similarly, for the (-2x) Japan fund, the correlation is $-0.29,-0.68$, and -0.78 for the one-day, four-day, and 21-day holding periods, respectively. The return correlation between the ILETFs and the SPX generally decreases slightly as the number of holding days increases, but still remains at a fairly high level. 
For countries with overlapping trading hours, the return correlation between ILETF and foreign broad market is higher. For the (2x) Brazil fund, this correlation is $0.87,0.91$, and 0.90 for the one, four, and 21 holding days, respectively.

Overall, our daily results show that ILETFs generally don't carry the promised amount of foreign market risk. To the contrary, these ILETFs actually carry significant amount of U.S. market risk. These findings suggest the limitations of these ILETFs as effective diversification tools into international markets on a daily basis. These ILETFs may play a placebo role to investors who want to diversify into foreign markets. 


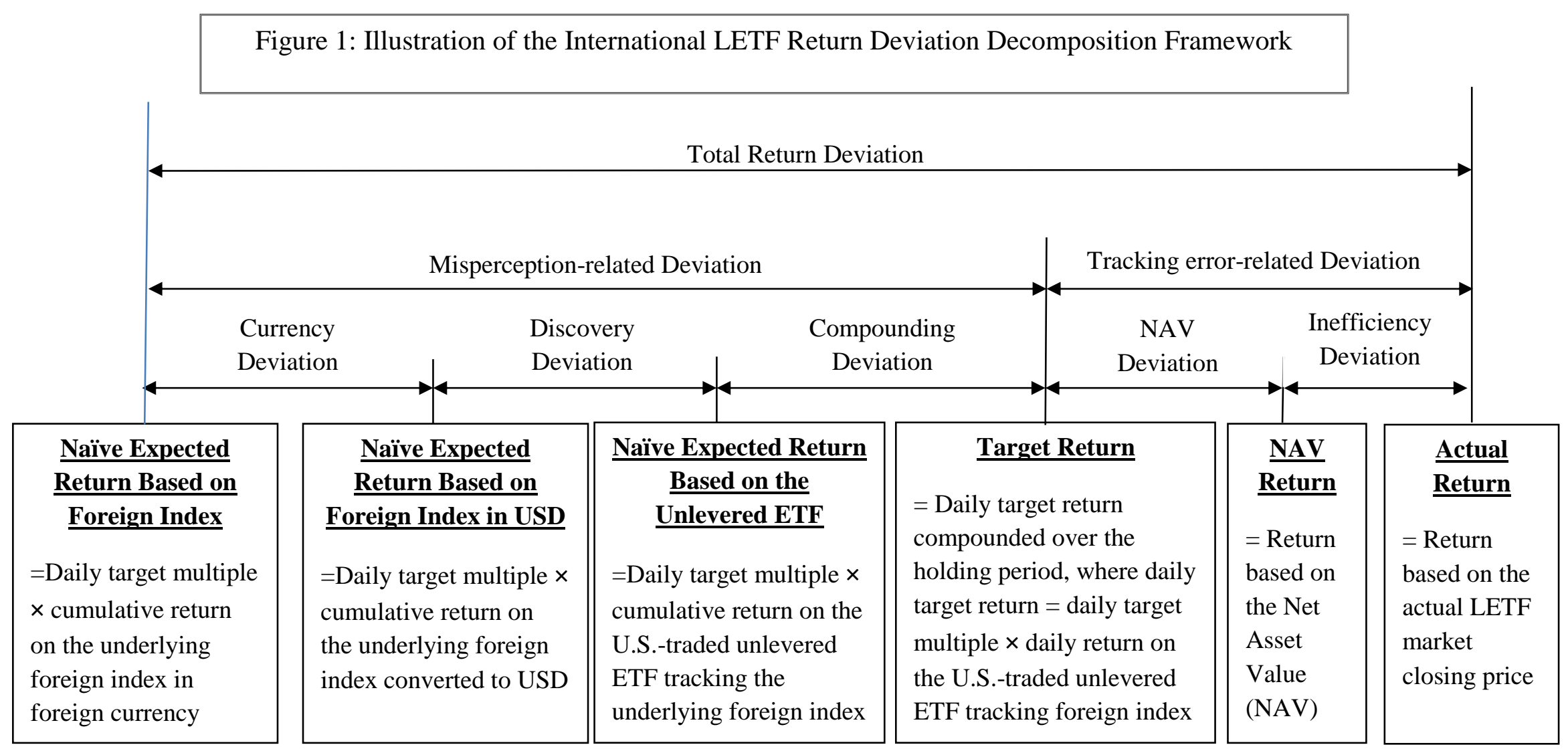




\section{Conclusion}

In this paper, we examine the return and tracking performance of U.S.-traded international leveraged ETFs. To conduct the analysis, we study the five families of LETFs tracking Brazil, China, Europe, Japan, and Mexico from their inception dates to May of 2012. We first examine how much actual exposure these ILETFs have with respect to their underlying foreign market indices using the single-index beta estimation. Our results show that ILETFs are significantly under-exposed to their underlying index for countries without overlapping trading hours. For example, the beta of $(-2 x)$ Japan fund is only -0.63 , which is far away from its target value of -2.0. These findings are important to our investment community as fund holders may not realize their intended exposure to the foreign markets, especially on a daily basis. The findings from bull funds are similar. For countries with overlapping trading hours, such as Brazil and Mexico, there is also a slight under-exposure. However, ILETFs tracking Europe are actually over-exposed to their underlying index.

To further understand why the market returns of these ILETFs deviate from their naïve expected counterparts, we expand the Tang and Xu (2013) LETF return deviation decomposition framework into a comprehensive framework for international LETFs. Our new framework includes five components of total return deviation: currency, discovery, compounding, NAV, and inefficiency deviations. Currency deviation reflects foreign exchange rate risk and is calculated as the naive expected return based on the underlying foreign market index denoted in USD minus the counterpart in foreign currency (if available). This currency deviation has a large positive (negative) contribution to the return deviations of bull (bear) Japan LETFs, as Japanese Yen appreciates against the USD during the sample period. On the other hand, the currency deviation has a negative (positive) contribution to the return deviations of bull (bear) Europe 
LETFs as Euro depreciates against USD during the sample period. Due to the peg between Hong Kong dollar and USD, there is little currency deviation for China LETFs. Since the underlying foreign market indices for the Brazil and Mexico ILETFs are both denominated in USD, there is no currency deviation for those funds.

The discovery deviation is computed as the naïve expected return based on the regular (1x) ETF less that based on the USD denoted index. This deviation component reflects the price discovery effect of new information in the location of the U.S. market during overlapping trading hours (for countries/regions such as Brazil, Mexico and Europe) and during non-synchronous trading hours (for countries/regions such as China, Japan, and Europe). Since the U.S.-traded unlevered (1x) ETF tracking the same underlying foreign market index is indeed the actual benchmark used by international LETFs, this discovery deviation is due to investors' misperception, but not due to the tracking error of LETF fund management. On a daily basis, the S\&P 500 index has a significant impact on the discovery deviation and this impact is more significant for countries without overlapping trading hours. In the meantime, the underlying index return and lagged valuation premium of the $(1 \mathrm{x})$ fund are important explanatory variables. The size and significance of the coefficients on the underlying index imply that the overall under-exposure of ILETFs to their underlying index is mainly driven by this price discovery component. In addition, the significance on the lagged valuation premium of the $(1 \mathrm{x})$ fund reflects a partial correction of the regular ETF mis-valuation from the previous trading day.

The NAV deviation intends to measure the ability of fund management to achieve an ILETF's target return. It is calculated as the NAV return of ILETFs less the naïve expected return based on the $(1 \mathrm{x})$ fund return. We find a negative coefficient on the lagged NAV deviation of LETF for both bull and bear ILETFs. This finding is consistent with the interpretation that 
fund management often has some inaccuracy in evaluating the NAV of an ILETF, which is corrected on the subsequent trading day. On a daily basis, the last component is the inefficiency deviation that reflects market inefficiency or trading frictions. This inefficiency deviation carries a self-correction process and is also associated with the (1x) fund return, suggesting some shortterm investor behaviors and a generally efficient mis-valuation correction mechanism. Overall, the drivers of total daily return deviations are the lagged ILETF valuation premium, lagged valuation premium of its corresponding regular $(1 \mathrm{x})$ ETF, lagged total deviation of ILETF, underlying index return, and S\&P 500 index return. The impact of these drivers is generally different between countries with and those without overlapping trading hours.

As we expand the holding period to multiple trading days, there is an additional component of compounding deviation, which is the difference between the daily leveraged benchmark return compounded over time and the leveraged multiple of the cumulative benchmark return. This deviation is due to the daily rebalancing need to achieve the constant daily leveraged multiple. Our findings show that the daily return variance negatively affects this deviation and the squared cumulative return positively affects this deviation.

It is worth noting that the S\&P 500 index has a large impact on the daily returns of ILETFs. This impact is larger for countries without overlapping trading hours than those with, and decays as the number of holding days increases. On the other hand, the return correlation between the ILETFs and their broad-based foreign home market indices increases as the holding period lengthens, especially for countries with overlapping trading hours. These findings are consistent with the behavioral interpretation of location bias that ILETFs overreact to U.S. market sentiments on a daily horizon and this overreaction is corrected over the time. To the investment community, our findings suggest that daily investors in ILETFs should be mindful of 
their under-exposure to the foreign broad market and over-exposure to the U.S. market. In addition, longer-term investors should pay special attention to the compounding deviation especially in highly volatile markets. In short, while the creation of ILETFs certainly expands investors' available choices to leverage their exposure to international markets, investors should realize that the market return of these funds can deviate from their naïve expectations substantially. A thorough understanding of the sources and important determinants of the return deviation on ILETFs is critical for efficient global asset allocation using these new and complicated financial instruments. 


\section{References}

Avellaneda, M., and S. Zhang, 2010. "Path-Dependence of Leveraged ETF Returns.” SIAM Journal of Financial Mathematics, 1, 586-603.

Bodurtha, J. N., D. S. Kim, and C. M. C. Lee, 1995. "Closed-end country funds and U.S. market sentiment." Review of Financial Studies, 8, 879-918.

Chan, K., A.J. Menkveld, and Z. Yang, 2008. "Information Asymmetry and Asset Prices: Evidence from the China Foreign Share Discount.” Journal of Finance, 63, 159-196.

Cheng, M., and A. Madhavan, 2009. “The Dynamics of Leveraged and Inverse Exchange-traded Funds.” Journal of Investment Management, 7, 43-62.

Coval, J. D., and Tobias J. M., 1999. "Home Bias at Home: Local Equity Preference in Domestic Portfolios.” Journal of Finance 54, 2045-2073.

Engle, R., and D. Sarkar. Summer 2006, "Premiums-Discounts and Exchange Traded Funds." Journal of Derivatives, 27-45.

Froot, K. A., and E. M. Dabora, 1999. How are stock prices affected by the location of trade? Journal of Financial Economics, 53,189-216.

Goetzmann, W.N., L. Li, and K. Geert, 2005. “Long-Term Global Market Correlations.” Journal of Business, 78, 1-38.

Gutierrez, J.A., V. Martinez, and Y. Tse, 2009. "Where Does Return and Volatility Come From? The Case of Asian ETFs.” International Review of Economics and Finance, 18, 671-679.

Hau, H., 2001. "Location Matters: An Examination of Trading Profits." Journal of Finance 56, 1959-1983.

Jorion, P., 1989. “Asset Allocation with Hedged and Unhedged Foreign Stocks and Bonds," Journal of Portfolio Management, 49-54. 
Levy, H., and M. Sarnat, 1970. "International Diversification of Investment Portfolios." American Economic Review, 60, 668-675.

Miffre, J., 2007. "Country-specific ETFs: An Efficient Approach to Global Asset Allocation." Journal of Asset Management, 8, 112-122.

Newey, W. K., and K. D. West. 1987. “A Simple, Positive Semi-definite, Heteroskedasticity and Autocorrelation Consistent Covariance Matrix." Econometrica, 55, 703-708.

Solnik, B., 1974. "Why Not Diversify Internationally Rather Than Domestically?" Financial Analysts Journal, 30, 102-116.

Tang, H., and X.E. Xu, 2013. "Solving the Return Deviation Conundrum of Leveraged Exchange-traded Funds.” Journal of Financial and Quantitative Analysis, 48, 309-342.

Tse, Y., and V. Martinez, 2007. "Price Discovery and Informational Efficiency of International iShares Funds." Global Finance Journal, 18, 1-15. 
Table 1: Daily Betas of International LETFs

This table shows daily beta estimation results for the international LETFs by regressing the LETF daily returns on its underlying index returns using the single-index model. The ending date for our sample is May 31, 2012. See Appendix A for variable definitions. Robust standard errors in parentheses; ${ }^{* * *} \mathrm{p}<1 \%,{ }^{* *} \mathrm{p}<5 \%,{ }^{*} \mathrm{p}<10 \%$ for the difference between the estimated beta and the LETF's target multiple.

Panel A: Daily beta of ETFs for countries without overlapping trading hours

\begin{tabular}{lcccccc}
\hline $\begin{array}{l}\text { Dep. Var. } \\
\text { Country: }\end{array}$ & \multicolumn{6}{c}{ Daily market return of ETFs } \\
Fund multiple & \multicolumn{1}{c}{ China (FTSE China 25 Index) } & & \multicolumn{3}{c}{ Japan (MSCI Japan Index) } \\
\cline { 2 - 6 } & $(-2 \mathrm{x})$ & $(1 \mathrm{x})$ & $(2 \mathrm{x})$ & $(-2 \mathrm{x})$ & $(1 \mathrm{x})$ & $(2 \mathrm{x})$ \\
\hline \multirow{3}{*}{ Index daily return } & $-1.142^{* * * *}$ & $0.601^{* * *}$ & $1.154^{* * *}$ & $-0.626^{* * *}$ & $0.309^{* * *}$ & $0.665^{* * *}$ \\
& $(0.105)$ & $(0.055)$ & $(0.092)$ & $(0.102)$ & $(0.057)$ & $(0.118)$ \\
Constant & -0.060 & 0.008 & 0.006 & -0.011 & -0.001 & 0.021 \\
& $(0.151)$ & $(0.078)$ & $(0.108)$ & $(0.096)$ & $(0.051)$ & $(0.082)$ \\
Observations & 1,148 & 1,148 & 754 & 1,148 & 1,148 & 753 \\
R-squared & 0.240 & 0.245 & 0.292 & 0.102 & 0.091 & 0.116 \\
F Statistics & 119.3 & 117.9 & 156.5 & 37.50 & 29.88 & 32.01 \\
\hline
\end{tabular}

Panel B: Daily beta of ETFs for countries with overlapping trading hours

\begin{tabular}{|c|c|c|c|c|c|c|c|c|c|}
\hline \multirow{3}{*}{$\begin{array}{l}\text { Dep. Var. } \\
\text { Country: }\end{array}$} & \multicolumn{9}{|c|}{ Daily market return of ETFs } \\
\hline & \multicolumn{9}{|c|}{ Mexico (MSCI Mexico Investable } \\
\hline & \multicolumn{3}{|c|}{ Brazil (MSCI Brazil Index) } & \multicolumn{3}{|c|}{ Market Index) } & \multicolumn{3}{|c|}{ Europe (MSCI Europe Index) } \\
\hline Fund multiple & $(-2 x)$ & $(1 \mathrm{x})$ & $(2 x)$ & $(-2 x)$ & $(1 \mathrm{x})$ & $(2 \mathrm{x})$ & $(-2 x)$ & $(1 \mathrm{x})$ & $(2 \mathrm{x})$ \\
\hline & (1) & (2) & (3) & (4) & (5) & (6) & (7) & (8) & (9) \\
\hline Index daily return & $\begin{array}{c}-1.876^{* * *} \\
(0.040)\end{array}$ & $\begin{array}{c}0.942 * * * \\
(0.020)\end{array}$ & $\begin{array}{c}1.837 * * * \\
(0.059)\end{array}$ & $\begin{array}{c}-1.748 * * * \\
(0.056)\end{array}$ & $\begin{array}{c}0.977 * * * \\
(0.023)\end{array}$ & $\begin{array}{c}1.119 * * * \\
(0.139)\end{array}$ & $\begin{array}{c}-2.268 * * * \\
(0.100)\end{array}$ & $\begin{array}{c}1.153 * * * \\
(0.051)\end{array}$ & $\begin{array}{c}2.227^{* * *} \\
(0.110)\end{array}$ \\
\hline Constant & $\begin{array}{c}-0.008 \\
(0.063)\end{array}$ & $\begin{array}{c}0.002 \\
(0.032)\end{array}$ & $\begin{array}{c}-0.011 \\
(0.080)\end{array}$ & $\begin{array}{c}-0.062 \\
(0.068)\end{array}$ & $\begin{array}{c}0.012 \\
(0.028)\end{array}$ & $\begin{array}{c}0.044 \\
(0.133)\end{array}$ & $\begin{array}{c}-0.001 \\
(0.090)\end{array}$ & $\begin{array}{l}-0.013 \\
(0.046)\end{array}$ & $\begin{array}{l}-0.015 \\
(0.108)\end{array}$ \\
\hline Observations & 743 & 743 & 527 & 744 & 744 & 526 & 744 & 744 & 526 \\
\hline R-squared & 0.800 & 0.797 & 0.764 & 0.662 & 0.778 & 0.239 & 0.569 & 0.568 & 0.575 \\
\hline F Statistics & 2188 & 2169 & 961.5 & 968.8 & 1770 & 64.63 & 512.7 & 516.9 & 412.1 \\
\hline
\end{tabular}

Panel C: Daily beta of ETFs for pooled sample across countries

\begin{tabular}{|c|c|c|c|c|c|c|}
\hline \multirow{2}{*}{ Dep. Var. } & \multicolumn{2}{|c|}{ Market return of (- } & \multicolumn{2}{|c|}{ Market return of $(2 x)$} & \multicolumn{2}{|c|}{$\frac{\text { Market return of }(1 x)}{\text { fund }}$} \\
\hline & (1) & (2) & (3) & (4) & (5) & (6) \\
\hline Index daily return & $\begin{array}{c}-1.283^{* * *} \\
(0.057)\end{array}$ & $\begin{array}{c}-1.921^{* * *} \\
(0.034)\end{array}$ & $\begin{array}{c}1.369 * * * \\
(0.052)\end{array}$ & $\begin{array}{c}1.697 * * * \\
(0.060)\end{array}$ & $\begin{array}{c}0.667 * * * \\
(0.031)\end{array}$ & $\begin{array}{c}0.999 * * * \\
(0.016)\end{array}$ \\
\hline Index daily return $\mathrm{x}$ & & $0.948 * * *$ & & $-0.716 * * *$ & & $-0.493 * * *$ \\
\hline No-overlapping & & $(0.088)$ & & $(0.095)$ & & $(0.047)$ \\
\hline No overlapping indica & & $\begin{array}{c}-0.018 \\
(0.100)\end{array}$ & & $\begin{array}{c}0.014 \\
(0.094)\end{array}$ & & $\begin{array}{c}0.006 \\
(0.052)\end{array}$ \\
\hline Constant & $\begin{array}{l}-0.052 \\
(0.052)\end{array}$ & $\begin{array}{l}-0.024 \\
(0.043)\end{array}$ & $\begin{array}{c}0.011 \\
(0.048)\end{array}$ & $\begin{array}{c}0.004 \\
(0.065)\end{array}$ & $\begin{array}{c}0.014 \\
(0.027)\end{array}$ & $\begin{array}{c}0.001 \\
(0.021)\end{array}$ \\
\hline Observations & 4,527 & 4,527 & 3,086 & 3,086 & 4,527 & 4,527 \\
\hline R-squared & 0.323 & 0.362 & 0.372 & 0.398 & 0.327 & 0.366 \\
\hline F Statistics & 501.3 & 1097 & 688.2 & 326.2 & 476.7 & 1282 \\
\hline
\end{tabular}


Table 2: Returns and Return Deviations of International LETFs

This table shows the summary statistics of various returns and return deviations of international LETFs. All returns and deviations are denoted in \%. The ending date for our sample is May 31, 2012. See Appendix A for variable definitions and Appendix B for details on the names and specifications on the regular and leveraged international ETFs.

Panel A: Summary statistics of various daily returns and return deviations for countries without synchronized trading

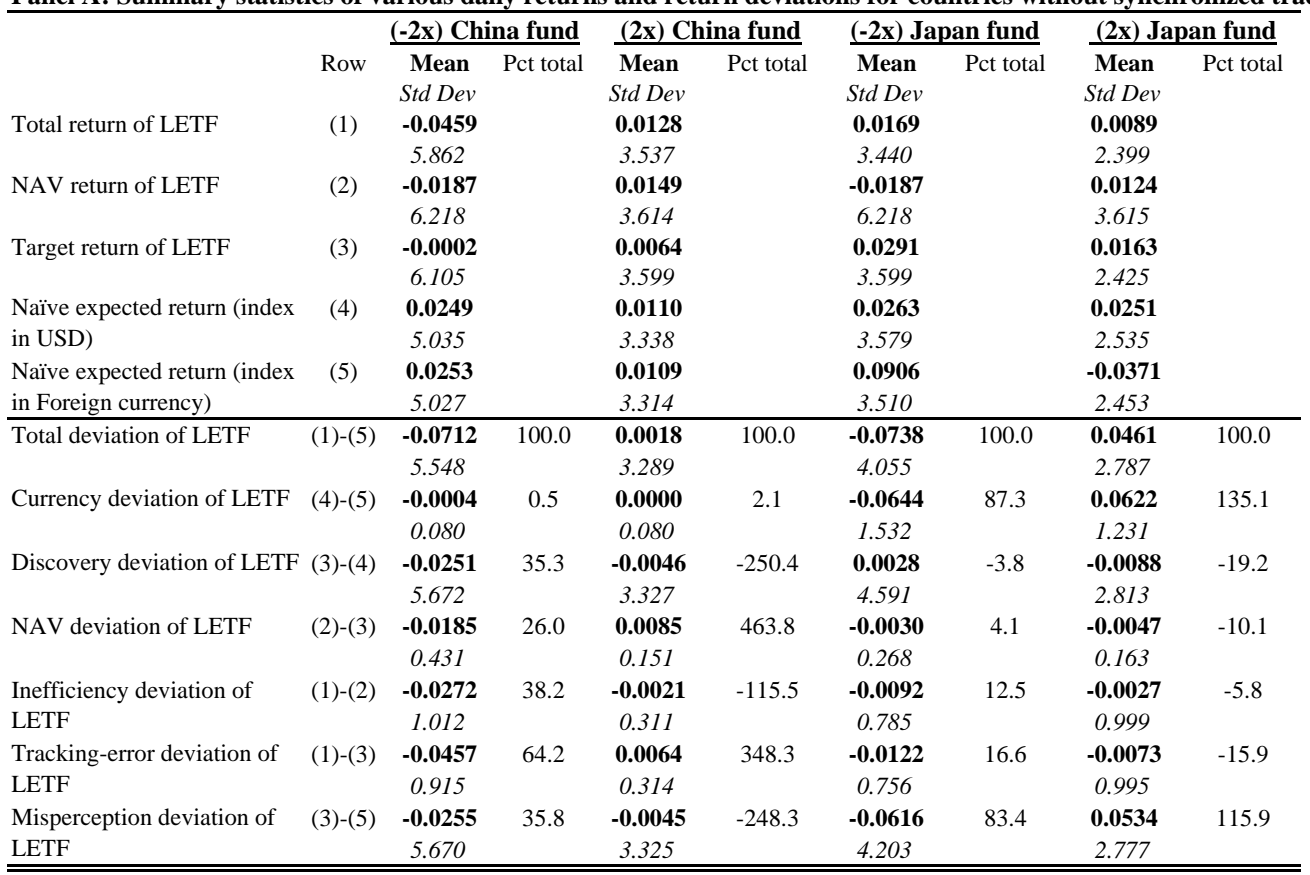

Panel B: Summary statistics of various daily returns and return deviations for countries/regions with synchronized trading

\begin{tabular}{|c|c|c|c|c|c|c|c|c|c|c|c|c|c|}
\hline \multirow{2}{*}{\multicolumn{2}{|c|}{ Row }} & \multicolumn{2}{|c|}{$(-2 x)$ Brazil fund } & \multicolumn{2}{|c|}{ (2x) Brazil fund } & \multicolumn{2}{|c|}{$(-2 x)$ Mexico fund } & \multicolumn{2}{|c|}{ (2x) Mexico fund } & \multicolumn{2}{|c|}{ (-2x) Europe fund } & \multicolumn{2}{|c|}{ (2x) Europe fund } \\
\hline & & $\begin{array}{c}\text { Mean } \\
\text { Std Dev }\end{array}$ & Pct total & $\begin{array}{l}\text { Mean } \\
\text { Std Dev }\end{array}$ & Pct total & $\begin{array}{l}\text { Mean } \\
\text { Std Dev }\end{array}$ & Pct total & $\begin{array}{c}\text { Mean } \\
\text { Std Dev }\end{array}$ & Pct total & $\begin{array}{c}\text { Mean } \\
\text { Std Dev }\end{array}$ & Pct total & $\begin{array}{l}\text { Mean } \\
\text { Std Dev }\end{array}$ & Pct total \\
\hline \multirow[t]{2}{*}{ Total return of LETF } & (1) & -0.0628 & & -0.0738 & & -0.1728 & & 0.0580 & & -0.0953 & & 0.0038 & \\
\hline & & 3.819 & & 3.776 & & 3.202 & & 3.480 & & 3.715 & & 3.779 & \\
\hline \multirow[t]{2}{*}{ NAV return of LETF } & (2) & -0.0408 & & -0.0245 & & -0.0415 & & -0.0230 & & -0.0415 & & -0.0230 & \\
\hline & & 3.614 & & 3.608 & & 3.611 & & 3.611 & & 3.611 & & 3.611 & \\
\hline \multirow[t]{2}{*}{ Target return of LETF } & (3) & -0.0581 & & -0.0709 & & -0.1476 & & 0.0470 & & -0.0689 & & 0.0155 & \\
\hline & & 3.843 & & 3.773 & & 3.303 & & 3.317 & & 3.782 & & 4.012 & \\
\hline \multirow{2}{*}{$\begin{array}{l}\text { Naïve expected return (index } \\
\text { in USD) }\end{array}$} & (4) & -0.0585 & & -0.0680 & & -0.1267 & & 0.0242 & & -0.0622 & & 0.0009 & \\
\hline & & 3.642 & & 3.591 & & 2.981 & & 3.038 & & 3.214 & & 3.346 & \\
\hline \multirow{2}{*}{$\begin{array}{l}\text { Naïve expected return (index } \\
\text { in Foreign currency) }\end{array}$} & (5) & -0.0585 & & -0.0680 & & -0.1267 & & 0.0242 & & -0.0830 & & 0.0170 & \\
\hline & & 3.642 & & 3.591 & & 2.981 & & 3.038 & & 2.471 & & 2.574 & \\
\hline \multirow[t]{2}{*}{ Total deviation of LETF } & (1)-(5) & -0.0043 & 100.0 & -0.0058 & 100.0 & -0.0461 & 100.0 & 0.0338 & 100.0 & -0.0123 & 100.0 & -0.0132 & 100.0 \\
\hline & & 1.721 & & 1.858 & & 1.898 & & 3.318 & & 2.461 & & 2.480 & \\
\hline \multirow[t]{2}{*}{ Currency deviation of LETF } & (4)-(5) & 0.0000 & 0.0 & 0.0000 & 0.0 & 0.0000 & 0.0 & 0.0000 & 0.0 & 0.0209 & -169.8 & -0.0161 & 122.0 \\
\hline & & 0.000 & & 0.000 & & 0.000 & & 0.000 & & 1.379 & & 1.461 & \\
\hline \multirow[t]{2}{*}{ Discovery deviation of LETF } & (3)-(4) & 0.0004 & -8.3 & -0.0029 & 50.7 & -0.0209 & 45.3 & 0.0228 & 67.2 & -0.0067 & 54.5 & 0.0146 & -110.5 \\
\hline & & 1.743 & & 1.740 & & 1.557 & & 1.513 & & 1.704 & & 1.814 & \\
\hline \multirow[t]{2}{*}{ NAV deviation of LETF } & (2)-(3) & -0.0071 & 163.8 & -0.0062 & 107.9 & -0.0162 & 35.1 & -0.0013 & -3.9 & -0.0246 & 200.0 & 0.0004 & -3.0 \\
\hline & & 0.146 & & 0.118 & & 0.152 & & 0.101 & & 0.104 & & 0.111 & \\
\hline \multirow{2}{*}{$\begin{array}{l}\text { Inefficiency deviation of } \\
\text { LETF }\end{array}$} & $(1)-(2)$ & 0.0024 & -55.5 & 0.0034 & -58.6 & -0.0090 & 19.6 & 0.0124 & 36.7 & -0.0019 & 15.3 & -0.0121 & 91.5 \\
\hline & & 0.396 & & 0.677 & & 1.640 & & 3.542 & & 0.571 & & 1.433 & \\
\hline \multirow{2}{*}{$\begin{array}{l}\text { Tracking-error deviation of } \\
\text { LETF }\end{array}$} & (1)-(3) & -0.0047 & 108.3 & -0.0028 & 49.3 & -0.0252 & 54.7 & 0.0111 & 32.8 & -0.0265 & 215.3 & -0.0117 & 88.5 \\
\hline & & 0.398 & & 0.683 & & 1.640 & & 3.555 & & 0.563 & & 1.426 & \\
\hline \multirow{2}{*}{$\begin{array}{l}\text { Misperception deviation of } \\
\text { LETF }\end{array}$} & (3)-(5) & 0.0004 & -8.3 & -0.0029 & 50.7 & -0.0209 & 45.3 & 0.0228 & 67.2 & 0.0142 & -115.3 & -0.0015 & 11.5 \\
\hline & & 1.743 & & 1.740 & & 1.557 & & 1.513 & & 2.516 & & 2.717 & \\
\hline
\end{tabular}


Table 3: Determinants of the ILETF's Daily Discovery Deviation

This table presents the determinants of the international LETF daily discovery deviations for countries/regions without overlaping trading hours (Panel A) and with overlapping trading hours (Panel B). The dependent variable is the daily discovery Panel A: Determinants of daily discovery return deviation for countries without overlaping trading hours

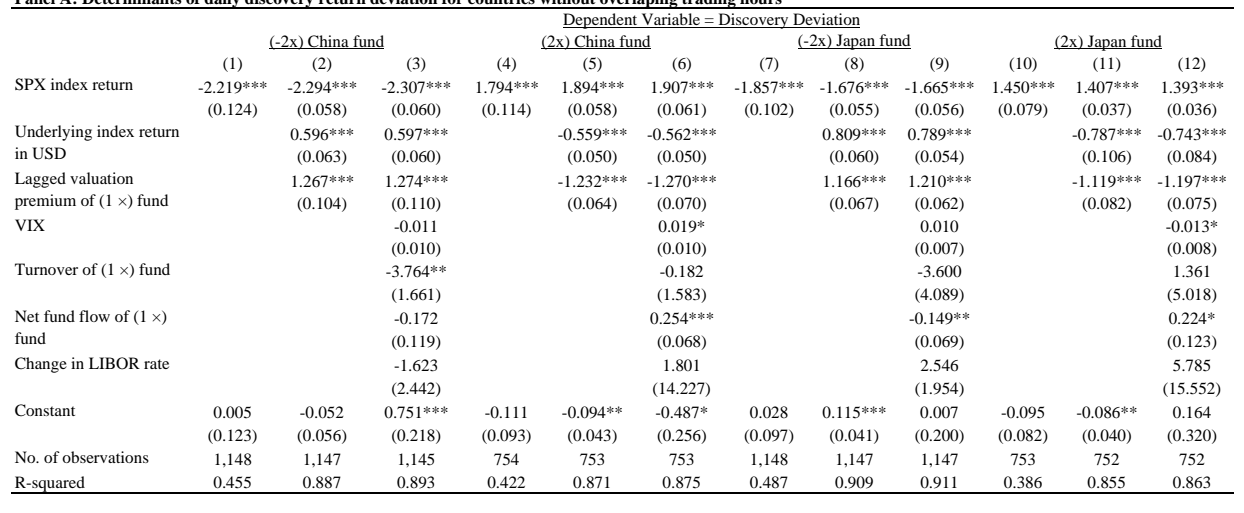

$\frac{\text { Panel B: Determinants of daily discovery return deviation for countries/regions with overlaping trading hours }}{(-2 \times) \text { Brazil fund }}$

\begin{tabular}{|c|c|c|c|c|c|c|c|c|c|c|c|c|c|c|c|c|c|c|}
\hline \multirow[b]{3}{*}{ SPX index return } & \multirow{2}{*}{\multicolumn{3}{|c|}{ (-2x) Brazil fund }} & \multicolumn{3}{|c|}{ (2x) Brazil fund } & \multicolumn{3}{|c|}{$(-2 x)$ Mexico fund } & \multicolumn{3}{|c|}{ (2x) Mexico fund } & \multicolumn{3}{|c|}{ (-2x) Europe fund } & \multicolumn{3}{|c|}{ (2x) Europe fund } \\
\hline & & & & (4) & & (6) & (7) & & (9) & (10) & & (12) & (13) & (14) & (15) & (16) & & (18) \\
\hline & $\begin{array}{c}-0.409+* * * \\
(0.066)\end{array}$ & $\begin{array}{l}-1.137 * * * \\
(0.077\end{array}$ & $\begin{array}{l}-1.122^{* * *} \\
(0.078)\end{array}$ & $\begin{array}{l}0.392 * * * ; \\
(0.788)\end{array}$ & $\begin{array}{l}1.112^{* * *} \\
(0.090)\end{array}$ & $\begin{array}{l}1.086 * * * * \\
(0.093)\end{array}$ & $\begin{array}{l}-0.492^{* * *} \\
(0.076)\end{array}$ & $\begin{array}{l}-0.768 * * * \\
(0.073)\end{array}$ & $\left.\begin{array}{l}-0.751 * * * \\
(0.078)\end{array}\right)$ & $\begin{array}{l}0.465 * * * \\
0.091)\end{array}$ & $\begin{array}{l}0.738^{* * * *} \\
(0.091\end{array}$ & $\begin{array}{l}0.711^{* * * *} \\
(.094)\end{array}$ & $\begin{array}{l}-0.748^{* * * *} \\
(0.067)\end{array}$ & $\begin{array}{l}-1.638 * * * \\
(0.080\end{array}$ & $\begin{array}{l}-1.654 * * * \\
(0.081)\end{array}$ & $\begin{array}{l}0.783^{* * *} \\
(0.080\end{array}$ & $\begin{array}{l}1.5322 * * * \\
0.065\end{array}$ & $\begin{array}{c}1.527 * * * \\
(0.067)\end{array}$ \\
\hline $\begin{array}{l}\text { Underlying index return } \\
\text { in USD }\end{array}$ & & $0.665 * * * *$ & $0.653 * * *$ & & $\begin{array}{l}-0.7000 * * * \\
-(0.063)\end{array}$ & $-0.0777 * * *$ & & $0.3477 * *$ & $0.346 * * *$ & & $\begin{array}{l}-0.3575 * * \\
-0.066)\end{array}$ & $\begin{array}{l}-0.0366^{* * *} \\
-0.065\end{array}$ & & 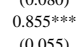 & $0.0 .854^{* * *}$ & & $-0.731 * * *+1$, & $\begin{array}{ll}-0.7288^{* * *} \\
-(0.45)\end{array}$ \\
\hline $\begin{array}{l}\text { In USD } \\
\text { Lagged valuation }\end{array}$ & & $0.384^{* * * *}$ & $0.445 * * *$ & & $-0.3499^{* * * *}$ & $-0.418^{* * * *}$ & & $1.771^{* * *}$ & $1.794 * * *$ & & $-1.787 * * *$ & $-1.795 * * *$ & & $\begin{array}{lll}0.0535) \\
0.743\end{array}$ & $\begin{array}{l}(0.0022) \\
0.708\end{array}$ & & $\begin{array}{l}(0.2804) \\
-2.20 * *\end{array}$ & 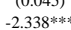 \\
\hline premium of $(1 \times)$ fund & & $(0.068)$ & $(0.074)$ & & $(0.078)$ & $(0.086)$ & & $(0.090)$ & $(0.088)$ & & $(0.115)$ & $(0.113)$ & & $(0.527)$ & $(0.529)$ & & $(0.161)$ & $(0.154)$ \\
\hline VIX & & & -0.003 & & & -0.010 & & & $0.014^{*}$ & & & $-0.016^{* * *}$ & & & -0.009 & & & -0.001 \\
\hline & & & $(0.012)$ & & & $(0.014)$ & & & $(0.008)$ & & & $(0.008)$ & & & $(0.009)$ & & & $(0.009)$ \\
\hline Turnover of $(1 \times)$ fund & & & -0.360 & & & 0.814 & & & -0.253 & & & 0.543 & & & -5.071 & & & 0.017 \\
\hline & & & (1.535) & & & $(1.861)$ & & & $(1.055)$ & & & $(1.202)$ & & & $(4.183)$ & & & (3.586) \\
\hline Net fund $\mathrm{fl}$ & & & $-0.494 * * *$ & & & $0.311^{* * *}$ & & & -0.036 & & & 0.022 & & & 0.0 & & & 0.037 \\
\hline & & & $(0.137)$ & & & $(0.111)$ & & & $(0.023)$ & & & $(0.026)$ & & & $(0.083)$ & & & $(0.087)$ \\
\hline Change in LIBOR rate & & & $\begin{array}{l}-17.438 \\
0.91750\end{array}$ & & & 32.571 & & & $-22.497 *$ & & & $\begin{array}{r}23.237 \\
197706\end{array}$ & & & $\begin{array}{l}7.579 \\
-19345\end{array}$ & & & $\begin{array}{l}-11.019 \\
-(1520)\end{array}$ \\
\hline Constant & 0.026 & $-0.120^{* *}$ & -0.045 & -0.016 & $0.118^{*}$ & 0. & 0.010 & $0.0777^{* *}$ & $\begin{array}{l}-0.204 \\
-1204\end{array}$ & 0.006 & $-0.090^{* *}$ & 0.206 & 0 & -0.037 & 0.292 & 13 & $* * * *$ & $0.300^{*}$ \\
\hline & $(0.062)$ & $(0.060)$ & $(0.262)$ & $(0.073)$ & $(0.071)$ & $(0.302)$ & $(0.053)$ & $(0.033)$ & $(0.169)$ & $(0.061)$ & $(0.036)$ & $(0.214)$ & $(0.053)$ & $(0.100)$ & $(0.223)$ & $(0.066)$ & $(0.052)$ & $(0.169)$ \\
\hline $\begin{array}{l}\text { No. of observations } \\
\text { R-suared }\end{array}$ & $\begin{array}{c}743 \\
0.080\end{array}$ & $\begin{array}{c}742 \\
0350\end{array}$ & ${ }_{0342}^{742}$ & 0.83 & $\begin{array}{c}526 \\
0372\end{array}$ & $\begin{array}{c}526 \\
0382\end{array}$ & $\begin{array}{c}744 \\
0.145\end{array}$ & $\begin{array}{l}743 \\
0664\end{array}$ & $\begin{array}{c}743 \\
0670\end{array}$ & $\begin{array}{c}526 \\
0.153\end{array}$ & $\begin{array}{c}525 \\
0.694\end{array}$ & $\begin{array}{r}525 \\
0700\end{array}$ & $\begin{array}{c}744 \\
0281\end{array}$ & $\begin{array}{c}743 \\
0614\end{array}$ & $\begin{array}{c}741 \\
0620\end{array}$ & $\begin{array}{c}526 \\
0303\end{array}$ & $\begin{array}{c}525 \\
0743\end{array}$ & $\begin{array}{c}523 \\
0745\end{array}$ \\
\hline
\end{tabular}

Panel C: Determinants of daily discovery return deviation of pooled sample across countries

\begin{tabular}{|c|c|c|c|c|c|c|c|c|}
\hline \multirow[b]{3}{*}{ SPX index return } & \multicolumn{3}{|c|}{$(-2 x)$ funds } & \multirow{3}{*}{$\begin{array}{c}(4) \\
-1.187 * * * \\
(0.047)\end{array}$} & \multirow{3}{*}{$\begin{array}{c}(5) \\
1.041^{* * *} \\
(0.047)\end{array}$} & \multicolumn{2}{|c|}{ (2x) funds } & \multirow[b]{2}{*}{ (8) } \\
\hline & & & (3) & & & (6) & (7) & \\
\hline & 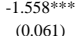 & $\begin{array}{c}-0.550^{* * * *} \\
(0.042)\end{array}$ & $\begin{array}{l}-1,190 * * * \\
(0.047)\end{array}$ & & & $\begin{array}{l}0.546^{* * *+*} \\
(0.050)\end{array}$ & $\begin{array}{l}1.213^{* * * *} \\
(0.047\end{array}$ & 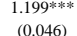 \\
\hline $\begin{array}{l}\text { SPX index return } x \text { No- } \\
\text { overlapping indicator }\end{array}$ & & $\begin{array}{l}-1.489+* * * \\
(0.089)\end{array}$ & $\begin{array}{l}-0.814^{* * * *} \\
(0.057)\end{array}$ & $\begin{array}{l}-0.818 * * * \\
(0.056)\end{array}$ & & $\begin{array}{c}1.076^{* * * *} \\
(0.087)\end{array}$ & $\begin{array}{c}0.463^{* * * *} \\
(0.057)\end{array}$ & $\begin{array}{c}0.475 * * * \\
(0.055)\end{array}$ \\
\hline No-overlapping & & -0.009 & $0.213^{* * * *}$ & $0.231^{* * * *}$ & & -0.096 & $-0.268^{* * *}$ & $0.259 * * * 4$ \\
\hline indicator & & $(0.085)$ & $(0.048)$ & $(0.045)$ & & $(0.073)$ & $(0.044)$ & $(0.045)$ \\
\hline $\begin{array}{l}\text { Underlying index return } \\
\text { in USD }\end{array}$ & & & $\begin{array}{c}0.644 * * * \\
(0.036)\end{array}$ & $\begin{array}{c}0.642^{2 * * *} \\
(0.034)\end{array}$ & & & $\begin{array}{l}-0.687 * *+4 \times \\
(0.032)\end{array}$ & $\begin{array}{c}-0.678^{* * * *} \\
(0.030)\end{array}$ \\
\hline Lagged valuation & & & $1.190 * * * *$ & $1.201^{* * * *}$ & & & $-1.040^{* * * *}$ & $1.060^{* * * * *}$ \\
\hline premium of $(1 \times)$ fund & & & & $(0.064)$ & & & & $(0.040)$ \\
\hline & & & & $\begin{array}{r}-0.003 \\
(0.005)\end{array}$ & & & & $\begin{array}{l}-0.005 \\
(0.005)\end{array}$ \\
\hline Turnover of $(1 \times)$ fund & & & & $-1.765 * * *$ & & & & 0.874 \\
\hline & & & & $(0.65$ & & & & $(0.807)$ \\
\hline $\begin{array}{l}\text { Net tund flow of }(1 x) \\
\text { fund }\end{array}$ & & & & $\begin{array}{l}-0.0120 \\
(0.042)\end{array}$ & & & & (0.048) \\
\hline Change in LIBOR rate & & & & 0.011 & & & & $15.940^{*}$ \\
\hline Constant & & & & & & & & \\
\hline & & & $(0.030$ & & & & $(0.031)$ & \\
\hline No. of ob & & & ) & $\left(\begin{array}{c}(.119) \\
4.518\end{array}\right.$ & & & & $\begin{array}{l}(0.1144) \\
3.079\end{array}$ \\
\hline R-squared & 0.363 & 0.436 & 0.841 & 0.843 & 0.273 & 0.346 & 0.762 & 0.765 \\
\hline
\end{tabular}


Table 4: Determinants of the ILETF's Daily NAV Deviation

This table presents the determinants of the international LETF daily NAV deviations for countries without overlaping trading hours (Panel A) and with overlapping trading hours (Panel B). The dependent variable is NAV deviation. See Appendix A for variable definitions. Robust standard errors in parentheses; ${ }^{* * *} \mathrm{p}<1 \%$, ${ }^{* *} \mathrm{p}<5 \%$, ${ }^{*} \mathrm{p}<10 \%$.

Panel A: Determinants of daily NAV return deviation for countries without overlaping trading hours

\begin{tabular}{|c|c|c|c|c|c|c|c|c|c|c|c|c|}
\hline & \multicolumn{8}{|c|}{ Dependent Variable = NAV Deviation } & & & & \\
\hline & \multicolumn{2}{|c|}{$(-2 x)$ China fund } & \multicolumn{2}{|c|}{ (2x) China fund } & \multicolumn{2}{|c|}{ (-2x) Japan fund } & \multicolumn{2}{|c|}{ (2x) Japan fund } & & & & \\
\hline & (2) & (3) & (4) & (5) & (7) & (8) & (9) & (10) & & & & \\
\hline Holding-period LIBOR & 2.641 & 2.357 & 0.793 & 0.204 & $4.526^{* * * *}$ & $3.888^{* * *}$ & -3.291 & -3.509 & & & & \\
\hline interest & (2.123) & (2.237) & (4.282) & $(4.302)$ & $(1.258)$ & $(1.285)$ & $(4.580)$ & (4.573) & & & & \\
\hline $\begin{array}{l}\text { Lagged NAV deviation } \\
\text { of LETF }\end{array}$ & $\begin{array}{c}-0.449 * * * \\
(0.081)\end{array}$ & $\begin{array}{c}-0.449 * * * \\
(0.080)\end{array}$ & $\begin{array}{c}-0.493^{* * * *} \\
(0.056)\end{array}$ & $\begin{array}{c}-0.498^{* * * *} \\
(0.056)\end{array}$ & $\begin{array}{c}-0.412 * * * * \\
(0.050)\end{array}$ & $\begin{array}{c}-0.424^{* * * *} \\
(0.050)\end{array}$ & $\begin{array}{c}-0.387 * * * \\
(0.052)\end{array}$ & $\begin{array}{c}-0.389 * * * \\
(0.050)\end{array}$ & & & & \\
\hline ( $1 \mathrm{x})$ fund return & $\begin{array}{c}-0.032 * * * \\
(0.008)\end{array}$ & $\begin{array}{c}-0.050^{* * *} \\
(0.016)\end{array}$ & $\begin{array}{l}0.007 * * \\
(0.003)\end{array}$ & $\begin{array}{c}0.007 \\
(0.006)\end{array}$ & $\begin{array}{c}-0.036 * * * \\
(0.007)\end{array}$ & $\begin{array}{c}-0.022^{* *} \\
(0.009)\end{array}$ & $\begin{array}{c}0.023 * * * \\
(0.006)\end{array}$ & $\begin{array}{c}0.032 * * * \\
(0.008)\end{array}$ & & & & \\
\hline SPX index return & & $\begin{array}{c}0.027 \\
(0.019)\end{array}$ & & $\begin{array}{l}-0.001 \\
(0.008)\end{array}$ & & $\begin{array}{l}-0.019^{*} \\
(0.010)\end{array}$ & & $\begin{array}{l}-0.008 \\
(0.008)\end{array}$ & & & & \\
\hline Underlying index return & & $\begin{array}{c}0.012 \\
(0.010)\end{array}$ & & $\begin{array}{c}0.003 \\
(0.005)\end{array}$ & & $\begin{array}{l}-0.004 \\
(0.006)\end{array}$ & & $\begin{array}{l}-0.005 \\
(0.006)\end{array}$ & & & & \\
\hline VIX & & $\begin{array}{c}0.000 \\
(0.002)\end{array}$ & & $\begin{array}{c}0.000 \\
(0.001)\end{array}$ & & $\begin{array}{l}-0.001 \\
(0.001)\end{array}$ & & $\begin{array}{c}0.001 \\
(0.001)\end{array}$ & & & & \\
\hline Turnover of $(1 \times)$ fund & & $\begin{array}{l}-0.219 \\
(0.346)\end{array}$ & & $\begin{array}{c}0.051 \\
(0.166)\end{array}$ & & $\begin{array}{l}-0.211 \\
(0.195)\end{array}$ & & $\begin{array}{c}0.114 \\
(0.186)\end{array}$ & & & & \\
\hline $\begin{array}{l}\text { Net fund flow of }(1 \times) \\
\text { fund }\end{array}$ & & $\begin{array}{c}0.010 \\
(0.018)\end{array}$ & & $\begin{array}{l}-0.012 \\
(0.009)\end{array}$ & & $\begin{array}{c}0.007 \\
(0.007)\end{array}$ & & $\begin{array}{l}-0.006 \\
(0.005)\end{array}$ & & & & \\
\hline Change in LIBOR rate & & $\begin{array}{l}-1.147^{*} \\
(0.589)\end{array}$ & & $\begin{array}{l}-0.994 \\
(1.531)\end{array}$ & & $\begin{array}{c}-0.867^{* *} \\
(0.395)\end{array}$ & & $\begin{array}{c}0.861 \\
(0.794)\end{array}$ & & & & \\
\hline Constant & $\begin{array}{c}-0.041^{* * *} \\
(0.009)\end{array}$ & $\begin{array}{l}-0.027 \\
(0.054)\end{array}$ & $\begin{array}{c}0.011 \\
(0.008)\end{array}$ & $\begin{array}{l}-0.005 \\
(0.024)\end{array}$ & $\begin{array}{c}-0.026 * * * \\
(0.008)\end{array}$ & $\begin{array}{c}0.023 \\
(0.030)\end{array}$ & $\begin{array}{l}-0.002 \\
(0.009)\end{array}$ & $\begin{array}{l}-0.029 \\
(0.026)\end{array}$ & & & & \\
\hline $\begin{array}{l}\text { No. of observations } \\
\text { R-squared }\end{array}$ & $\begin{array}{l}1,147 \\
0.259\end{array}$ & $\begin{array}{l}1,145 \\
0.277\end{array}$ & $\begin{array}{c}753 \\
0.251\end{array}$ & $\begin{array}{c}753 \\
0.254\end{array}$ & $\begin{array}{l}1,147 \\
0.236\end{array}$ & $\begin{array}{l}1,147 \\
0.255\end{array}$ & $\begin{array}{c}752 \\
0.183\end{array}$ & $\begin{array}{c}752 \\
0.190\end{array}$ & & & & \\
\hline & $(-2 x) \mathrm{Br}$ & azil fund & (2x) Bra & zil fund & $(-2 x)$ Mex & kico fund & $(2 \mathrm{x}) \mathrm{Mex}$ & kico fund & $(-2 x) \mathrm{Eu}$ & ope fund & (2x) Eur & ope fund \\
\hline & (2) & (3) & (4) & (5) & (7) & (8) & (9) & (10) & (12) & (13) & (14) & (15) \\
\hline $\begin{array}{l}\text { Holding-period LIBOR } \\
\text { interest }\end{array}$ & $\begin{array}{l}-0.011 \\
(3.864)\end{array}$ & $\begin{array}{c}0.055 \\
(4.058)\end{array}$ & $\begin{array}{l}-2.220 \\
(3.456)\end{array}$ & $\begin{array}{l}-2.564 \\
(3.522)\end{array}$ & $\begin{array}{l}-0.080 \\
(4.577)\end{array}$ & $\begin{array}{c}0.803 \\
(4.651)\end{array}$ & $\begin{array}{l}-5.641^{*} \\
(2.953)\end{array}$ & $\begin{array}{c}-6.170^{* *} \\
(2.989)\end{array}$ & $\begin{array}{l}-0.472 \\
(3.176)\end{array}$ & $\begin{array}{l}-0.390 \\
(3.159)\end{array}$ & $\begin{array}{c}1.842 \\
(3.800)\end{array}$ & $\begin{array}{c}1.673 \\
(3.739)\end{array}$ \\
\hline $\begin{array}{l}\text { Lagged NAV deviation } \\
\text { of LETF }\end{array}$ & $\begin{array}{c}-0.488^{* * * *} \\
(0.094)\end{array}$ & $\begin{array}{c}-0.488^{* * *} \\
(0.094)\end{array}$ & $\begin{array}{c}-0.507 * * * \\
(0.138)\end{array}$ & $\begin{array}{c}-0.508^{* * * *} \\
(0.139)\end{array}$ & $\begin{array}{c}-0.488^{* * * *} \\
(0.168)\end{array}$ & $\begin{array}{c}-0.484^{* * *} \\
(0.168)\end{array}$ & $\begin{array}{c}-0.293^{* * *} \\
(0.105)\end{array}$ & $\begin{array}{c}-0.286^{* * * *} \\
(0.104)\end{array}$ & $\begin{array}{c}-0.493 * * * \\
(0.082)\end{array}$ & $\begin{array}{c}-0.490^{* * *} \\
(0.083)\end{array}$ & $\begin{array}{c}-0.509 * * * \\
(0.098)\end{array}$ & $\begin{array}{c}-0.504 * * * * \\
(0.099)\end{array}$ \\
\hline (1 x) fund return & $\begin{array}{l}-0.001 \\
(0.003)\end{array}$ & $\begin{array}{l}-0.004 \\
(0.006)\end{array}$ & $\begin{array}{l}-0.000 \\
(0.002)\end{array}$ & $\begin{array}{l}-0.002 \\
(0.006)\end{array}$ & $\begin{array}{c}0.003 \\
(0.002)\end{array}$ & $\begin{array}{l}0.016^{*} \\
(0.010)\end{array}$ & $\begin{array}{l}-0.002 \\
(0.002)\end{array}$ & $\begin{array}{l}-0.009 \\
(0.006)\end{array}$ & $\begin{array}{c}-0.006 * * \\
(0.003)\end{array}$ & $\begin{array}{l}-0.006 \\
(0.006)\end{array}$ & $\begin{array}{l}0.007 * * \\
(0.003)\end{array}$ & $\begin{array}{c}0.005 \\
(0.007)\end{array}$ \\
\hline SPX index return & & $\begin{array}{l}-0.002 \\
(0.007)\end{array}$ & & $\begin{array}{l}-0.003 \\
(0.006)\end{array}$ & & $\begin{array}{l}-0.013 \\
(0.008)\end{array}$ & & $\begin{array}{c}0.004 \\
(0.006)\end{array}$ & & $\begin{array}{l}-0.003 \\
(0.009)\end{array}$ & & $\begin{array}{c}0.004 \\
(0.011)\end{array}$ \\
\hline Underlying index return & & $\begin{array}{l}0.005 \\
(0.005)\end{array}$ & & $\begin{array}{c}0.003 \\
(0.004)\end{array}$ & & $\begin{array}{l}-0.006 \\
(0.007)\end{array}$ & & $\begin{array}{l}0.005 \\
(0.004)\end{array}$ & & $\begin{array}{c}0.002 \\
(0.006)\end{array}$ & & $\begin{array}{l}-0.001 \\
(0.007)\end{array}$ \\
\hline VIX & & $\begin{array}{l}-0.000 \\
(0.001)\end{array}$ & & $\begin{array}{l}0.000 \\
(0.001)\end{array}$ & & $\begin{array}{l}-0.000 \\
(0.000)\end{array}$ & & $\begin{array}{c}0.000 \\
(0.001)\end{array}$ & & $\begin{array}{c}0.000 \\
(0.001)\end{array}$ & & $\begin{array}{c}0.000 \\
(0.001)\end{array}$ \\
\hline Turnover of $(1 \times)$ fund & & $\begin{array}{c}0.033 \\
(0.149)\end{array}$ & & $\begin{array}{l}-0.164 \\
(0.101)\end{array}$ & & $\begin{array}{c}0.015 \\
(0.078)\end{array}$ & & $\begin{array}{l}-0.020 \\
(0.070)\end{array}$ & & $\begin{array}{l}-0.235 \\
(0.309)\end{array}$ & & $\begin{array}{c}0.256 \\
(0.353)\end{array}$ \\
\hline $\begin{array}{l}\text { Net fund flow of }(1 \times) \\
\text { fund }\end{array}$ & & $\begin{array}{l}-0.005 \\
(0.006)\end{array}$ & & $\begin{array}{c}0.001 \\
(0.005)\end{array}$ & & $\begin{array}{l}-0.002 \\
(0.003)\end{array}$ & & $\begin{array}{c}0.001 \\
(0.003)\end{array}$ & & $\begin{array}{l}-0.003 \\
(0.006)\end{array}$ & & $\begin{array}{c}0.008 \\
(0.008)\end{array}$ \\
\hline Change in LIBOR rate & & $\begin{array}{l}-0.054 \\
(1.251)\end{array}$ & & $\begin{array}{c}0.170 \\
(1.114)\end{array}$ & & $\begin{array}{c}0.610 \\
(0.814)\end{array}$ & & $\begin{array}{l}-0.854 \\
(1.133)\end{array}$ & & $\begin{array}{l}-0.675 \\
(1.118)\end{array}$ & & $\begin{array}{c}0.550 \\
(1.677)\end{array}$ \\
\hline Constant & $\begin{array}{l}-0.010 \\
(0.007)\end{array}$ & $\begin{array}{l}-0.004 \\
(0.022)\end{array}$ & $\begin{array}{l}-0.006 \\
(0.007)\end{array}$ & $\begin{array}{c}0.004 \\
(0.016)\end{array}$ & $\begin{array}{c}-0.024^{* * * *} \\
(0.009)\end{array}$ & $\begin{array}{l}-0.020 \\
(0.017)\end{array}$ & $\begin{array}{c}0.007 \\
(0.008)\end{array}$ & $\begin{array}{c}0.009 \\
(0.018)\end{array}$ & $\begin{array}{c}-0.036 * * * \\
(0.006)\end{array}$ & $\begin{array}{c}-0.032^{* * *} \\
(0.015)\end{array}$ & $\begin{array}{l}-0.002 \\
(0.007)\end{array}$ & $\begin{array}{l}-0.020 \\
(0.019)\end{array}$ \\
\hline No. of observations & 742 & 742 & 526 & 526 & 743 & 743 & 525 & 525 & 743 & 741 & 525 & 523 \\
\hline R-squared & 0.239 & 0.240 & 0.259 & 0.263 & 0.240 & 0.244 & 0.089 & 0.093 & 0.251 & 0.255 & 0.268 & 0.276 \\
\hline
\end{tabular}

Panel C: Determinants of daily NAV return deviation for pooled sample across countries

\begin{tabular}{|c|c|c|c|c|c|c|c|c|}
\hline \multirow[b]{3}{*}{$\begin{array}{l}\text { Holding-period LIBOR } \\
\text { interest }\end{array}$} & \multicolumn{4}{|c|}{$(-2 x)$ funds } & \multicolumn{4}{|c|}{ (2x) funds } \\
\hline & (2) & (3) & (4) & (5) & (7) & (8) & (9) & (10) \\
\hline & $\begin{array}{c}0.631 \\
(2.906)\end{array}$ & $\begin{array}{c}3.467 * * * \\
(1.198)\end{array}$ & $\begin{array}{l}-0.203 \\
(2.411)\end{array}$ & $\begin{array}{l}-0.184 \\
(2.530)\end{array}$ & $\begin{array}{l}-4.996 * \\
(2.730)\end{array}$ & $\begin{array}{l}-1.965 \\
(1.871)\end{array}$ & $\begin{array}{l}-2.646 \\
(2.089)\end{array}$ & $\begin{array}{l}-2.721 \\
(2.099)\end{array}$ \\
\hline $\begin{array}{l}\text { Lagged NAV deviation } \\
\text { of LETF }\end{array}$ & & $\begin{array}{c}-0.444^{* * * *} \\
(0.053)\end{array}$ & $\begin{array}{c}-0.484 * * * \\
(0.082)\end{array}$ & $\begin{array}{c}-0.485 * * * \\
(0.082)\end{array}$ & & $\begin{array}{c}-0.438^{* * *} \\
(0.037)\end{array}$ & $\begin{array}{c}-0.443^{* * *} \\
(0.078)\end{array}$ & $\begin{array}{c}-0.444^{* * * *} \\
(0.078)\end{array}$ \\
\hline$(1 \mathrm{x})$ fund return & & $\begin{array}{c}-0.022^{* * *} \\
(0.004)\end{array}$ & $\begin{array}{l}-0.002 \\
(0.002)\end{array}$ & $\begin{array}{l}-0.005 \\
(0.007)\end{array}$ & & $\begin{array}{c}0.006^{* * *} \\
(0.002)\end{array}$ & $\begin{array}{c}0.002 \\
(0.002)\end{array}$ & $\begin{array}{c}0.005 \\
(0.003)\end{array}$ \\
\hline $\begin{array}{l}\text { Holding-period LIBOR } \\
\text { interest x No- }\end{array}$ & $\begin{array}{c}2.376 \\
(3.204)\end{array}$ & & $\begin{array}{c}3.780 \\
(2.711)\end{array}$ & $\begin{array}{l}3.253 \\
(2.763)\end{array}$ & $\begin{array}{c}1.956 \\
(4.435)\end{array}$ & & $\begin{array}{c}1.432 \\
(3.796)\end{array}$ & $\begin{array}{l}1.196 \\
(3.805)\end{array}$ \\
\hline $\begin{array}{l}\text { Lagged NAV deviation } \\
\text { of LETF x No- }\end{array}$ & & & $\begin{array}{c}0.046 \\
(0.101)\end{array}$ & $\begin{array}{c}0.040 \\
(0.101)\end{array}$ & & & $\begin{array}{c}0.007 \\
(0.087)\end{array}$ & $\begin{array}{c}0.008 \\
(0.087)\end{array}$ \\
\hline $\begin{array}{l}\text { (1 x) fund return } \mathrm{x} \text { No- } \\
\text { overlapping indicator }\end{array}$ & & & $\begin{array}{l}-0.031^{* * * *} \\
(0.006)\end{array}$ & $\begin{array}{l}-0.029^{* * * *} \\
(0.006)\end{array}$ & & & $\begin{array}{c}0.010^{* * * *} \\
(0.003)\end{array}$ & $\begin{array}{c}0.009^{* * * *} \\
(0.003)\end{array}$ \\
\hline $\begin{array}{l}\text { No-overlapping } \\
\text { indicator }\end{array}$ & $\begin{array}{l}-0.008 \\
(0.008)\end{array}$ & & $\begin{array}{l}-0.010 \\
(0.007)\end{array}$ & $\begin{array}{l}-0.009 \\
(0.007)\end{array}$ & $\begin{array}{c}0.001 \\
(0.008)\end{array}$ & & $\begin{array}{c}0.004 \\
(0.008)\end{array}$ & $\begin{array}{c}0.004 \\
(0.008)\end{array}$ \\
\hline SPX index return & & & & $\begin{array}{l}-0.001 \\
(0.008)\end{array}$ & & & & $\begin{array}{c}-0.002 \\
(0.004)\end{array}$ \\
\hline Underlying index return & & & & $\begin{array}{c}0.005 \\
(0.005)\end{array}$ & & & & $\begin{array}{l}-0.002 \\
(0.003)\end{array}$ \\
\hline VIX & & & & $\begin{array}{l}-0.001 \\
(0.001)\end{array}$ & & & & $\begin{array}{c}0.000 \\
(0.000)\end{array}$ \\
\hline Turnover of $(1 \times)$ fund & & & & $\begin{array}{l}-0.080 \\
(0.104)\end{array}$ & & & & $\begin{array}{c}0.021 \\
(0.046)\end{array}$ \\
\hline $\begin{array}{l}\text { Net fund flow of }(1 \times) \\
\text { fund }\end{array}$ & & & & $\begin{array}{c}0.004 \\
(0.005)\end{array}$ & & & & $\begin{array}{l}-0.002 \\
(0.002)\end{array}$ \\
\hline Change in LIBOR rate & & & & $\begin{array}{c}-0.988 * * * \\
(0.349)\end{array}$ & & & & $\begin{array}{l}-0.093 \\
(0.610)\end{array}$ \\
\hline Constant & $\begin{array}{c}-0.017^{* * *} \\
(0.005)\end{array}$ & $\begin{array}{c}-0.030^{* * *} \\
(0.003)\end{array}$ & $\begin{array}{l}-0.023^{* * *} \\
(0.004)\end{array}$ & $\begin{array}{l}-0.003 \\
(0.022)\end{array}$ & $\begin{array}{c}0.005 \\
(0.005)\end{array}$ & $\begin{array}{c}0.002 \\
(0.004)\end{array}$ & $\begin{array}{c}0.001 \\
(0.004)\end{array}$ & $\begin{array}{c}-0.010 \\
(0.009)\end{array}$ \\
\hline No. of observations & 4,527 & 4,522 & 4,522 & 4,518 & 3,086 & 3,081 & 3,081 & 3,079 \\
\hline R-squared & 0.003 & 0.234 & 0.249 & 0.260 & 0.001 & 0.199 & 0.203 & 0.204 \\
\hline
\end{tabular}


Table 5: Determinants of the ILETF's Daily Inefficiency Deviation

This table presents the determinants of the international LETF daily inefficiency deviations for countries without overlaping trading hours (Panel A) and with overlapping trading hours (Panel B). The dependent variable is inefficiency deviation. See Appendix A for variable definitions. Robust standard errors in parentheses; ${ }^{* * *} \mathrm{p}<1 \%$, ${ }^{* *} \mathrm{p}<5 \%$, ${ }^{*} \mathrm{p}<10 \%$.

\begin{tabular}{|c|c|c|c|c|c|c|c|c|c|c|c|c|}
\hline & & & Dependen & t Variable $=$ & Inefficiency & Deviation & & & & & & \\
\hline & $(-2 x) C h$ & ina fund & (2x) Chi & ina fund & $(-2 \mathrm{x}) \mathrm{Ja}$ & pan fund & (2x) Jap & an fund & & & & \\
\hline & (1) & (2) & (3) & (4) & (5) & (6) & (7) & (8) & & & & \\
\hline Lagged valuation premium of LETF & $\begin{array}{c}-1.018^{* * *} \\
(0.050)\end{array}$ & $\begin{array}{c}-0.997 * * * \\
(0.046)\end{array}$ & $\begin{array}{c}-0.961^{* * *} \\
(0.038)\end{array}$ & $\begin{array}{c}-0.965^{* * *} \\
(0.030)\end{array}$ & $\begin{array}{c}-0.936^{* * *} \\
(0.043)\end{array}$ & $\begin{array}{c}-0.888^{* * *} \\
(0.035)\end{array}$ & $\begin{array}{c}-0.926^{* * *} \\
(0.092)\end{array}$ & $\begin{array}{c}-0.911 * * * \\
(0.089)\end{array}$ & & & & \\
\hline (1 x) fund return & & $\begin{array}{c}0.089^{* * *} \\
(0.017)\end{array}$ & & $\begin{array}{c}-0.043^{* * * *} \\
(0.009)\end{array}$ & & $\begin{array}{c}0.189 * * * \\
(0.035)\end{array}$ & & $\begin{array}{c}-0.178^{* * * *} \\
(0.041)\end{array}$ & & & & \\
\hline Underlying index return & & $\begin{array}{l}0.047^{* * *} \\
(0.020)\end{array}$ & & $\begin{array}{l}-0.012 \\
(0.009)\end{array}$ & & $\begin{array}{l}-0.000 \\
(0.013)\end{array}$ & & $\begin{array}{l}-0.008 \\
(0.028)\end{array}$ & & & & \\
\hline SPX index return & & $\begin{array}{l}-0.013 \\
(0.038)\end{array}$ & & $\begin{array}{c}0.016 \\
(0.011)\end{array}$ & & $\begin{array}{c}-0.058^{* *} \\
(0.029)\end{array}$ & & $\begin{array}{c}0.023 \\
(0.039)\end{array}$ & & & & \\
\hline Change in LIBOR rate & & $\begin{array}{c}2.425 \\
(1.888)\end{array}$ & & $\begin{array}{c}-4.428^{* * *} \\
(1.475)\end{array}$ & & $\begin{array}{l}-0.265 \\
(0.489)\end{array}$ & & $\begin{array}{l}-6.603 \\
(5.504)\end{array}$ & & & & \\
\hline VIX & & $\begin{array}{l}-0.000 \\
(0.004)\end{array}$ & & $\begin{array}{l}0.004^{*} \\
(0.002)\end{array}$ & & $\begin{array}{c}0.001 \\
(0.003)\end{array}$ & & $\begin{array}{l}0.008^{* *} \\
(0.004)\end{array}$ & & & & \\
\hline Turnover of LETF & & $\begin{array}{l}0.053^{*} \\
(0.030)\end{array}$ & & $\begin{array}{c}0.080 \\
(0.123)\end{array}$ & & $\begin{array}{c}0.152 \\
(0.260)\end{array}$ & & $\begin{array}{l}-0.010 \\
(0.169)\end{array}$ & & & & \\
\hline Net fund flow of LETF & & $\begin{array}{c}0.001 \\
(0.007)\end{array}$ & & $\begin{array}{l}-0.001 \\
(0.001)\end{array}$ & & $\begin{array}{l}-0.001 \\
(0.004)\end{array}$ & & $\begin{array}{l}-0.004 \\
(0.003)\end{array}$ & & & & \\
\hline Constant & $\begin{array}{l}-0.030 \\
(0.019)\end{array}$ & $\begin{array}{l}-0.060 \\
(0.090)\end{array}$ & $\begin{array}{c}0.012 \\
(0.008)\end{array}$ & $\begin{array}{l}-0.089 * \\
(0.047)\end{array}$ & $\begin{array}{l}-0.010 \\
(0.017)\end{array}$ & $\begin{array}{l}-0.037 \\
(0.065)\end{array}$ & $\begin{array}{c}-0.094 * * * \\
(0.031)\end{array}$ & $\begin{array}{c}-0.271^{* * *} \\
(0.085)\end{array}$ & & & & \\
\hline No. of observations & 1,148 & 1,148 & 754 & 754 & 1,148 & 1,148 & 753 & 753 & & & & \\
\hline R-squared & 0.584 & 0.700 & 0.511 & 0.582 & 0.488 & 0.599 & 0.467 & 0.511 & & & & \\
\hline & $(-2 \mathrm{x}) \mathrm{Br}$ & azil fund & (2x) Bra & azil fund & $(-2 x) M e$ & xico fund & (2x) Mex & kico fund & $(-2 x) \mathrm{Eu}$ & ope fund & (2x) Eur & ope fund \\
\hline & (1) & $(2)$ & (3) & (4) & (5) & (6) & (7) & (8) & (9) & $(10)$ & (11) & $(12)$ \\
\hline Lagged valuation premium of LETF & $\begin{array}{c}-0.833^{* * *} \\
(0.095)\end{array}$ & $\begin{array}{c}-0.814^{* * *} \\
(0.087)\end{array}$ & $\begin{array}{c}-1.068^{* * *} \\
(0.085)\end{array}$ & $\begin{array}{c}-1.056^{* * *} \\
(0.082)\end{array}$ & $\begin{array}{c}-0.689 * * * \\
(0.075)\end{array}$ & $\begin{array}{c}-0.662 * * * \\
(0.074)\end{array}$ & $\begin{array}{c}-0.346 * * * \\
(0.072)\end{array}$ & $\begin{array}{c}-0.342^{* * *} \\
(0.072)\end{array}$ & $\begin{array}{c}-0.950 * * * \\
(0.056)\end{array}$ & $\begin{array}{c}-0.947 * * * \\
(0.055)\end{array}$ & $\begin{array}{c}-0.903 * * * \\
(0.071)\end{array}$ & $\begin{array}{c}-0.853^{* * *} \\
(0.071)\end{array}$ \\
\hline$(1 \mathrm{x})$ fund return & & $\begin{array}{c}0.071^{* * *} \\
(0.022)\end{array}$ & & $\begin{array}{l}-0.036 \\
(0.034)\end{array}$ & & $\begin{array}{c}0.505 * * * \\
(0.099)\end{array}$ & & $\begin{array}{c}-1.262^{* * *} \\
(0.248)\end{array}$ & & $\begin{array}{c}0.074^{* * *} \\
(0.021)\end{array}$ & & $\begin{array}{c}-0.313^{* * * *} \\
(0.066)\end{array}$ \\
\hline Underlying index return & & $\begin{array}{c}-0.037^{* *} \\
(0.018)\end{array}$ & & $\begin{array}{l}-0.035 \\
(0.026)\end{array}$ & & $\begin{array}{c}-0.168^{* *} \\
(0.079)\end{array}$ & & $\begin{array}{l}0.420 * \\
(0.216)\end{array}$ & & $\begin{array}{l}-0.030 \\
(0.019)\end{array}$ & & $\begin{array}{c}0.211^{* * *} \\
(0.057)\end{array}$ \\
\hline SPX index return & & $\begin{array}{c}-0.035 * * \\
(0.015)\end{array}$ & & $\begin{array}{c}0.071^{* * *} \\
(0.027)\end{array}$ & & $\begin{array}{l}-0.146 \\
(0.097)\end{array}$ & & $\begin{array}{l}-0.268 \\
(0.230)\end{array}$ & & $\begin{array}{l}-0.000 \\
(0.028)\end{array}$ & & $\begin{array}{l}-0.017 \\
(0.092)\end{array}$ \\
\hline Change in LIBOR rate & & $\begin{array}{l}-2.035 \\
(4.097)\end{array}$ & & $\begin{array}{c}-16.501^{* *} \\
(8.060)\end{array}$ & & $\begin{array}{c}-22.117^{* * *} \\
(7.772)\end{array}$ & & $\begin{array}{r}-43.669 \\
(34.271)\end{array}$ & & $\begin{array}{c}2.117 \\
(3.721)\end{array}$ & & $\begin{array}{c}-15.162 * \\
(8.365)\end{array}$ \\
\hline VIX & & $\begin{array}{l}-0.001 \\
(0.003)\end{array}$ & & $\begin{array}{c}0.003 \\
(0.004)\end{array}$ & & $\begin{array}{c}0.013 \\
(0.009)\end{array}$ & & $\begin{array}{l}-0.029 \\
(0.023)\end{array}$ & & $\begin{array}{l}-0.001 \\
(0.003)\end{array}$ & & $\begin{array}{c}0.006 \\
(0.008)\end{array}$ \\
\hline Turnover of LETF & & $\begin{array}{c}0.061 \\
(0.118)\end{array}$ & & $\begin{array}{c}0.495 \\
(0.454)\end{array}$ & & $\begin{array}{l}-0.020 \\
(0.405)\end{array}$ & & $\begin{array}{c}1.946 \\
(6.004)\end{array}$ & & $\begin{array}{l}0.304 * \\
(0.176)\end{array}$ & & $\begin{array}{c}0.412 \\
(0.606)\end{array}$ \\
\hline Net fund flow of LETF & & $\begin{array}{c}0.000 \\
(0.001)\end{array}$ & & $\begin{array}{c}0.004 \\
(0.004)\end{array}$ & & $\begin{array}{l}0.006^{*} \\
(0.003)\end{array}$ & & $\begin{array}{c}-0.065^{* * * *} \\
(0.007)\end{array}$ & & $\begin{array}{l}0.003 * \\
(0.002)\end{array}$ & & $\begin{array}{c}0.031^{* * *} \\
(0.010)\end{array}$ \\
\hline Constant & $\begin{array}{c}0.001 \\
(0.011)\end{array}$ & $\begin{array}{c}0.015 \\
(0.044)\end{array}$ & $\begin{array}{c}0.022 \\
(0.019)\end{array}$ & $\begin{array}{l}-0.073 \\
(0.067)\end{array}$ & $\begin{array}{c}0.025 \\
(0.049)\end{array}$ & $\begin{array}{l}-0.291 \\
(0.202)\end{array}$ & $\begin{array}{l}-0.053 \\
(0.143)\end{array}$ & $\begin{array}{c}0.637 \\
(0.524)\end{array}$ & $\begin{array}{c}0.015 \\
(0.015)\end{array}$ & $\begin{array}{c}0.004 \\
(0.055)\end{array}$ & $\begin{array}{l}-0.053 \\
(0.046)\end{array}$ & $\begin{array}{l}-0.212 \\
(0.174)\end{array}$ \\
\hline No. of observations & 743 & 743 & 527 & 527 & 744 & 744 & 526 & 526 & 744 & 744 & 526 & 526 \\
\hline R-squared & 0.451 & 0.472 & 0.524 & 0.542 & 0.346 & 0.433 & 0.171 & 0.445 & 0.476 & 0.520 & 0.452 & 0.566 \\
\hline
\end{tabular}

Panel C: Determinants of daily discovery return deviation of pooled sample across countries

\begin{tabular}{|c|c|c|c|c|}
\hline \multirow[b]{3}{*}{ Lagged valuation premium of LETF } & \multicolumn{2}{|c|}{$(-2 x)$ funds } & \multicolumn{2}{|c|}{ (2x) funds } \\
\hline & (1) & (2) & (3) & (4) \\
\hline & $\begin{array}{l}-0.716^{* * *} \\
(0.066)\end{array}$ & $\begin{array}{l}-0.710^{* * *} \\
(0.065)\end{array}$ & $\begin{array}{l}-0.387^{* * *} \\
(0.070)\end{array}$ & $\begin{array}{c}-0.388^{* * *} \\
(0.069)\end{array}$ \\
\hline $\begin{array}{l}\text { Lagged valuation premium of LETF } x \\
\text { No-overlapping indicator }\end{array}$ & $\begin{array}{c}-0.272 * * * \\
(0.075)\end{array}$ & $\begin{array}{c}-0.241^{* * * *} \\
(0.074)\end{array}$ & $\begin{array}{c}-0.532 * * * \\
(0.107)\end{array}$ & $\begin{array}{c}-0.500^{* * *} \\
(0.102)\end{array}$ \\
\hline No-overlapping indicator & $\begin{array}{l}-0.033 \\
(0.022)\end{array}$ & $\begin{array}{l}-0.039 * \\
(0.020)\end{array}$ & $\begin{array}{l}-0.014 \\
(0.054)\end{array}$ & $\begin{array}{l}-0.022 \\
(0.049)\end{array}$ \\
\hline (1 x) fund return & & $\begin{array}{c}0.119^{* * *} \\
(0.014)\end{array}$ & & $\begin{array}{c}-0.195^{* * *} \\
(0.033)\end{array}$ \\
\hline Underlying index return & & $\begin{array}{c}0.014 \\
(0.012)\end{array}$ & & $\begin{array}{l}-0.030 \\
(0.026)\end{array}$ \\
\hline SPX index return & & $\begin{array}{l}-0.029^{*} \\
(0.017)\end{array}$ & & $\begin{array}{c}-0.097 * * \\
(0.042)\end{array}$ \\
\hline Change in LIBOR rate & & $\begin{array}{c}0.884 \\
(1.016)\end{array}$ & & $\begin{array}{c}-20.173^{* *} \\
(8.112)\end{array}$ \\
\hline VIX & & $\begin{array}{c}0.002 \\
(0.002)\end{array}$ & & $\begin{array}{l}-0.003 \\
(0.005)\end{array}$ \\
\hline Turnover of LETF & & $\begin{array}{c}0.023 \\
(0.030)\end{array}$ & & $\begin{array}{c}0.158 \\
(0.247)\end{array}$ \\
\hline Net fund flow of LETF & & $\begin{array}{c}0.002 \\
(0.002)\end{array}$ & & $\begin{array}{l}-0.003 \\
(0.004)\end{array}$ \\
\hline Constant & $\begin{array}{c}0.013 \\
(0.018)\end{array}$ & $\begin{array}{l}-0.031 \\
(0.046)\end{array}$ & $\begin{array}{l}-0.027 \\
(0.051)\end{array}$ & $\begin{array}{c}0.036 \\
(0.109)\end{array}$ \\
\hline No. of observations & 4,527 & 4,527 & 3,086 & 3,086 \\
\hline R-squared & 0.443 & 0.508 & 0.217 & 0.294 \\
\hline
\end{tabular}


Table 6: Determinants of the ILETF's Daily Total Return Deviation

This table presents the determinants of the international LETF daily discovery deviations for countries without overlaping trading hours (Panel A) and with overlapping trading hours (Panel B). The dependent variable is discovery deviation. See Appendix A for variable definitions. Robust standard errors in parentheses; ${ }^{* * *} \mathrm{p}<1 \%,{ }^{* *} \mathrm{p}<5 \%,{ }^{*} \mathrm{p}<10 \%$,

Panel A: Determinants of total daily return deviation for countries without overlaping trading hours

\begin{tabular}{|c|c|c|c|c|c|c|c|c|}
\hline & \multicolumn{8}{|c|}{ Dependent Variable $=$ Total Daily Deviation } \\
\hline & \multicolumn{2}{|c|}{$(-2 x)$ China fund } & \multicolumn{2}{|c|}{ (2x) China fund } & \multicolumn{2}{|c|}{ (-2x) Japan fund } & \multicolumn{2}{|c|}{ (2x) Japan fund } \\
\hline & (1) & (2) & (3) & (4) & (5) & (6) & (7) & (8) \\
\hline SPX index return & $\begin{array}{l}-2.233^{* * *} \\
(0.063)\end{array}$ & $\begin{array}{l}-2.245 * * * \\
(0.063)\end{array}$ & $\begin{array}{c}1.877 * * * \\
(0.058)\end{array}$ & $\begin{array}{l}1.896^{* * *} \\
(0.061)\end{array}$ & $\begin{array}{c}-1.423 * * * \\
(0.054)\end{array}$ & $\begin{array}{c}-1.405 * * * \\
(0.051)\end{array}$ & $\begin{array}{c}1.190 * * * \\
(0.054)\end{array}$ & $\begin{array}{c}1.168 * * * \\
(0.054)\end{array}$ \\
\hline Underlying index return & $\begin{array}{c}0.650 * * * \\
(0.065)\end{array}$ & $\begin{array}{l}0.659 * * * \\
(0.062)\end{array}$ & $\begin{array}{c}-0.590 * * * \\
(0.050)\end{array}$ & $\begin{array}{c}-0.591 * * * \\
(0.050)\end{array}$ & $\begin{array}{c}1.006 * * * \\
(0.069)\end{array}$ & $\begin{array}{c}0.993^{* * *} \\
(0.059)\end{array}$ & $\begin{array}{c}-0.931 * * * \\
(0.133)\end{array}$ & $\begin{array}{c}-0.807 * * * \\
(0.080)\end{array}$ \\
\hline Lagged valuation premium of LETF & $\begin{array}{c}-1.094^{* * * *} \\
(0.212)\end{array}$ & $\begin{array}{l}-1.035 * * * \\
(0.205)\end{array}$ & $\begin{array}{l}-0.404^{*} \\
(0.223)\end{array}$ & $\begin{array}{c}-0.506 * * \\
(0.216)\end{array}$ & $\begin{array}{l}-0.577 * * * \\
(0.117)\end{array}$ & $\begin{array}{c}-0.573^{* * *} \\
(0.116)\end{array}$ & $\begin{array}{c}-0.829 * * * \\
(0.088)\end{array}$ & $\begin{array}{c}-0.859 * * * * \\
(0.092)\end{array}$ \\
\hline $\begin{array}{l}\text { Lagged valuation premium of }(1 \times) \\
\text { fund }\end{array}$ & $\begin{array}{c}1.153 * * * \\
(0.097)\end{array}$ & $\begin{array}{l}1.124 * * * \\
(0.097)\end{array}$ & $\begin{array}{c}-1.131 * * * \\
(0.077)\end{array}$ & $\begin{array}{c}-1.180^{* * *} \\
(0.087)\end{array}$ & $\begin{array}{c}0.899 * * * \\
(0.077)\end{array}$ & $\begin{array}{c}0.948^{* * *} \\
(0.072)\end{array}$ & $\begin{array}{c}-0.974 * * * \\
(0.099)\end{array}$ & $\begin{array}{c}-1.069 * * * \\
(0.092)\end{array}$ \\
\hline Lagged total deviation of LETF & $\begin{array}{l}-0.083^{* * * *} \\
(0.025)\end{array}$ & $\begin{array}{c}-0.092 * * * \\
(0.024)\end{array}$ & $\begin{array}{l}-0.033 \\
(0.024)\end{array}$ & $\begin{array}{l}-0.026 \\
(0.024)\end{array}$ & $\begin{array}{l}-0.035 \\
(0.026)\end{array}$ & $\begin{array}{l}-0.029 \\
(0.025)\end{array}$ & $\begin{array}{c}-0.073 * * * \\
(0.025)\end{array}$ & $\begin{array}{c}-0.068 * * * \\
(0.024)\end{array}$ \\
\hline Holding-period LIBOR interest & & $\begin{array}{c}21.102 \\
(14.522)\end{array}$ & & $\begin{array}{l}-35.201 \\
(41.265)\end{array}$ & & $\begin{array}{c}-21.783 * * \\
(9.841)\end{array}$ & & $\begin{array}{l}-102.582^{* *} \\
(50.697)\end{array}$ \\
\hline VIX & & $\begin{array}{l}-0.006 \\
(0.010)\end{array}$ & & $\begin{array}{l}0.022 * * \\
(0.010)\end{array}$ & & $\begin{array}{c}0.006 \\
(0.007)\end{array}$ & & $\begin{array}{c}0.007 \\
(0.008)\end{array}$ \\
\hline Turnover of $(1 \times)$ fund & & $\begin{array}{l}-3.976 * * \\
(1.836)\end{array}$ & & $\begin{array}{c}0.074 \\
(1.561)\end{array}$ & & $\begin{array}{c}-7.428 * * \\
(3.029)\end{array}$ & & $\begin{array}{l}-4.092 \\
(3.732)\end{array}$ \\
\hline Net fund flow of $(1 \times)$ fund & & $\begin{array}{l}-0.126 \\
(0.099)\end{array}$ & & $\begin{array}{c}0.216^{* * *} \\
(0.066)\end{array}$ & & $\begin{array}{c}-0.148 * * \\
(0.068)\end{array}$ & & $\begin{array}{c}0.151 \\
(0.112)\end{array}$ \\
\hline Turnover of LETF & & $\begin{array}{c}-0.084 \\
(0.108)\end{array}$ & & $\begin{array}{c}-0.118 \\
(0.693)\end{array}$ & & $\begin{array}{l}2.293^{* *} \\
(1.102)\end{array}$ & & $\begin{array}{l}2.421^{* *} \\
(0.975)\end{array}$ \\
\hline Net fund flow of LETF & & $\begin{array}{c}-0.004 \\
(0.018)\end{array}$ & & $\begin{array}{c}0.005 \\
(0.008)\end{array}$ & & $\begin{array}{c}-0.020 \\
(0.018)\end{array}$ & & $\begin{array}{l}-0.024 \\
(0.016)\end{array}$ \\
\hline Change in LIBOR rate & & $\begin{array}{c}-0.181 \\
(3.078)\end{array}$ & & $\begin{array}{c}-4.140 \\
(14.325)\end{array}$ & & $\begin{array}{l}4.090^{* *} \\
(1.978)\end{array}$ & & $\begin{array}{c}-15.536 \\
(13.742)\end{array}$ \\
\hline Constant & $\begin{array}{c}-0.103^{*} \\
(0.056)\end{array}$ & $\begin{array}{c}0.586 * * * * \\
(0.226)\end{array}$ & $\begin{array}{l}-0.083^{*} \\
(0.043)\end{array}$ & $\begin{array}{c}-0.530 * * \\
(0.245)\end{array}$ & $\begin{array}{c}0.050 \\
(0.044)\end{array}$ & $\begin{array}{c}0.197 \\
(0.211)\end{array}$ & $\begin{array}{c}-0.126^{* *} \\
(0.049)\end{array}$ & $\begin{array}{c}-0.017 \\
(0.254)\end{array}$ \\
\hline & 1,147 & 1,145 & 753 & 753 & 1,147 & 1,147 & 752 & 752 \\
\hline R-squared & 0.885 & 0.890 & 0.871 & 0.875 & 0.864 & 0.869 & 0.774 & 0.788 \\
\hline
\end{tabular}

Panel B: Determinants of total daily return deviation for countries/regions with overlaping trading hours

\begin{tabular}{|c|c|c|c|c|c|c|c|c|c|c|c|c|}
\hline \multirow[b]{3}{*}{ SPX in } & \multicolumn{2}{|c|}{$(-2 x)$ Brazil fund } & \multicolumn{2}{|c|}{ (2x) Brazil fund } & \multicolumn{2}{|c|}{ (-2x) Mexico fund } & \multicolumn{2}{|c|}{ (2x) Mexico fund } & \multicolumn{2}{|c|}{$(-2 x)$ Europe fund } & \multicolumn{2}{|c|}{ (2x) Europe fund } \\
\hline & & & (3) & (4) & (5) & (6) & (7) & (8) & (9) & $(10)$ & & $(12)$ \\
\hline & $\begin{array}{c}-0.990^{* * * *} \\
(0.071)\end{array}$ & $\begin{array}{c}-0.983 * * * \\
(0.073)\end{array}$ & $\begin{array}{c}1.011^{* * *} \\
(0.090)\end{array}$ & $\begin{array}{c}1.008^{* * * *} \\
(0.091)\end{array}$ & $\begin{array}{c}-0.692^{* * *} \\
(0.085)\end{array}$ & $\begin{array}{l}-0.659 * * * \\
(0.089)\end{array}$ & $\begin{array}{c}0.092 \\
(0.185)\end{array}$ & $\begin{array}{c}0.068 \\
(0.185)\end{array}$ & $\begin{array}{l}-2.184 * * * \\
(0.078)\end{array}$ & $\begin{array}{l}-2.203^{* * *} \\
(0.080)\end{array}$ & $\begin{array}{c}1.869^{* * *} \\
(0.091)\end{array}$ & $\begin{array}{c}1.880^{* * *} \\
(0.094)\end{array}$ \\
\hline Underlying index return & $\begin{array}{c}0.561^{1 * *} \\
(0.048)\end{array}$ & $\begin{array}{c}0.547 * * * \\
(0.048)\end{array}$ & $\begin{array}{c}-0.633^{* * *} \\
(0.066)\end{array}$ & $\begin{array}{c}-0.638^{* * * *} \\
(0.067)\end{array}$ & $\begin{array}{c}0.564 * * * \\
(0.075)\end{array}$ & $\begin{array}{l}0.564^{* * *} \\
(0.076)\end{array}$ & $\begin{array}{c}-1.044^{* * *} \\
(0.178)\end{array}$ & $\begin{array}{l}-1.096 * * * \\
(0.169)\end{array}$ & $\begin{array}{c}1.237 * * * \\
(0.081)\end{array}$ & $\begin{array}{l}1.243^{* * *} \\
(0.080)\end{array}$ & $\begin{array}{c}-1.047^{* * *} \\
(0.095)\end{array}$ & $\begin{array}{c}-1.086 * * * \\
(0.097)\end{array}$ \\
\hline Lagged valuation premium of LETF & $\begin{array}{l}-0.074 \\
(0.151)\end{array}$ & $\begin{array}{l}-0.123 \\
(0.146)\end{array}$ & $\begin{array}{c}-0.612^{* * *} \\
(0.142)\end{array}$ & $\begin{array}{c}-0.637 * * * \\
(0.138)\end{array}$ & $\begin{array}{l}-0.669^{* * *} \\
(0.089)\end{array}$ & $\begin{array}{l}-0.688^{* * *} \\
(0.090)\end{array}$ & $\begin{array}{c}-0.304 * * * \\
(0.082)\end{array}$ & $\begin{array}{l}-0.295 * * * \\
(0.082)\end{array}$ & $\begin{array}{l}-0.643^{* * *} \\
(0.139)\end{array}$ & $\begin{array}{c}-0.648^{* * *} \\
(0.141)\end{array}$ & $\begin{array}{l}-0.851^{* * *} \\
(0.098)\end{array}$ & $\begin{array}{l}-0.881 * * * \\
(0.097)\end{array}$ \\
\hline $\begin{array}{l}\text { Lagged valuation premium of }(1 \times) \\
\text { fund }\end{array}$ & $\begin{array}{c}0.232 * * * \\
(0.061)\end{array}$ & $\begin{array}{c}0.287 * * * \\
(0.068)\end{array}$ & $\begin{array}{l}-0.230 * * * \\
(0.075)\end{array}$ & $\begin{array}{c}-0.326 * * * \\
(0.087)\end{array}$ & $\begin{array}{c}1.484^{* * *} \\
(0.165)\end{array}$ & $\begin{array}{l}1.571^{* * *} \\
(0.169)\end{array}$ & $\begin{array}{l}-0.328 \\
(0.351)\end{array}$ & $\begin{array}{c}-0.401 \\
(0.361)\end{array}$ & $\begin{array}{c}0.306 \\
(0.342)\end{array}$ & $\begin{array}{c}0.283 \\
(0.343)\end{array}$ & $\begin{array}{c}-1.777 * * * \\
(0.247)\end{array}$ & $\begin{array}{c}-1.916 * * * \\
(0.265)\end{array}$ \\
\hline Lagged total deviation of LETF & $\begin{array}{c}-0.304 * * * \\
(0.035)\end{array}$ & $\begin{array}{c}-0.296 * * * \\
(0.035)\end{array}$ & $\begin{array}{c}-0.291 * * * \\
(0.045)\end{array}$ & $\begin{array}{c}-0.281 * * * \\
(0.044)\end{array}$ & $\begin{array}{c}0.011 \\
(0.045)\end{array}$ & $\begin{array}{c}0.026 \\
(0.045)\end{array}$ & $\begin{array}{c}-0.123^{* *} \\
(0.054)\end{array}$ & $\begin{array}{c}-0.118^{* * *} \\
(0.054)\end{array}$ & $\begin{array}{c}-0.151 * * * \\
(0.032)\end{array}$ & $\begin{array}{c}-0.155^{* * *} \\
(0.031)\end{array}$ & $\begin{array}{l}-0.063 * * \\
(0.030)\end{array}$ & $\begin{array}{l}-0.053^{*} \\
(0.030)\end{array}$ \\
\hline Holding-period LIBOR interest & & $\begin{array}{c}130.141^{* * *} \\
(45.203)\end{array}$ & & $\begin{array}{l}-127.199 * * \\
(55.136)\end{array}$ & & $\begin{array}{c}70.107 \\
(47.721)\end{array}$ & & $\begin{array}{c}14.526 \\
(107.767)\end{array}$ & & $\begin{array}{c}78.084 \\
(47.684)\end{array}$ & & $\begin{array}{c}-9.940 \\
(65.031)\end{array}$ \\
\hline VIX & & $\begin{array}{c}-0.006 \\
(0.012)\end{array}$ & & $\begin{array}{l}-0.002 \\
(0.014)\end{array}$ & & $\begin{array}{l}0.022^{*} \\
(0.011)\end{array}$ & & $\begin{array}{c}-0.013 \\
(0.023)\end{array}$ & & $\begin{array}{l}-0.016 \\
(0.011)\end{array}$ & & $\begin{array}{c}0.012 \\
(0.014)\end{array}$ \\
\hline Turnover of $(1 \times)$ fund & & 0.0 & & -0. & & & & & & & & \\
\hline & & $(1.5$ & & $(2.1)-1$ & & $(1$. & & 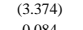 & & 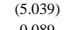 & & 9) \\
\hline Net fund flow of $(1 \times)$ fund & & $\begin{array}{l}-0.235^{*} \\
(0.126)\end{array}$ & & $\begin{array}{c}0.156 \\
(0.107)\end{array}$ & & $\begin{array}{c}-0.070^{* *} \\
(0.033)\end{array}$ & & $\begin{array}{c}0.084 \\
(0.085)\end{array}$ & & $\begin{array}{c}0.089 \\
(0.078)\end{array}$ & & $\begin{array}{l}-0.019 \\
(0.077)\end{array}$ \\
\hline Turnove & & $\begin{array}{c}-0.497 \\
(0.561)\end{array}$ & & & & & & $\begin{array}{c}2.637 \\
(6.084)\end{array}$ & & & & \\
\hline Net fund flow of LETF & & 0.008 & & $0.032^{* *}$ & & $\begin{array}{l}0.010^{* *} \\
0.005\end{array}$ & & $-0.065 * * *$ & & $0.011^{*}$ & & $0.041^{* * *}$ \\
\hline Change in LIBOR rate & & $\begin{array}{c}(0.011) \\
-9.158 \\
(15.302)\end{array}$ & & $\begin{array}{c}(0.013) \\
3.056 \\
(17.035)\end{array}$ & & $\begin{array}{c}(0.005) \\
-36.870^{* * *} \\
(10.920)\end{array}$ & & $\begin{array}{c}(0.006) \\
-15.744 \\
(34.065)\end{array}$ & & $\begin{array}{c}(0.006) \\
23.528 \\
(24.084)\end{array}$ & & $\begin{array}{r}(0.008) \\
-24.605 \\
(24.591)\end{array}$ \\
\hline Constant & $\begin{array}{c}-0.066 \\
(0.056)\end{array}$ & $\begin{array}{c}-0.107 \\
(0.268)\end{array}$ & $\begin{array}{c}0.068 \\
(0.075)\end{array}$ & $\begin{array}{c}0.240 \\
(0.327)\end{array}$ & $\begin{array}{c}0.058 \\
(0.053)\end{array}$ & $\begin{array}{c}-0.454^{* * *} \\
(0.224)\end{array}$ & $\begin{array}{c}-0.028 \\
(0.126)\end{array}$ & $\begin{array}{l}1.004^{*} \\
(0.582)\end{array}$ & $\begin{array}{c}0.041 \\
(0.077)\end{array}$ & $\begin{array}{c}0.369 \\
(0.238)\end{array}$ & $\begin{array}{l}0.140 * \\
(0.075)\end{array}$ & $\begin{array}{c}0.027 \\
(0.299)\end{array}$ \\
\hline & 742 & 74 & 526 & . & 743 & 1.2 & 52 & 52 & 743 & 741 & 525 & 523 \\
\hline R-squared & 0.437 & 0.449 & 0.476 & 0.490 & 0.472 & 0.492 & 0.354 & 0.376 & 0.680 & 0.686 & 0.647 & 0.656 \\
\hline
\end{tabular}

Panel C: Determinants of total daily return deviation for pooled sample across countries

\begin{tabular}{|c|c|c|c|c|c|c|c|c|}
\hline & \multicolumn{4}{|c|}{ (-2x) funds } & \multicolumn{4}{|c|}{ (2x) funds } \\
\hline & (1) & (2) & (3) & (4) & (5) & (6) & (7) & (8) \\
\hline SPX index return & $\begin{array}{c}-1.710^{* * *} \\
(0.039)\end{array}$ & $\begin{array}{c}-1.379 * * * \\
(0.050)\end{array}$ & $\begin{array}{c}-1.388^{* * *} \\
(0.051)\end{array}$ & $\begin{array}{c}-1.715 * * * \\
(0.039)\end{array}$ & $\begin{array}{c}1.307 * * * \\
(0.042)\end{array}$ & $\begin{array}{c}1.057 * * * \\
(0.085)\end{array}$ & $\begin{array}{c}1.052^{* * *} \\
(0.087)\end{array}$ & $\begin{array}{c}1.298^{* * *} \\
(0.043)\end{array}$ \\
\hline Underlying index return & $\begin{array}{l}0.849 * * * \\
(0.037)\end{array}$ & $\begin{array}{c}0.834 * * * \\
(0.039)\end{array}$ & $\begin{array}{l}0.840 * * * \\
(0.039)\end{array}$ & $\begin{array}{c}0.851^{* * *} \\
(0.035)\end{array}$ & $\begin{array}{c}-0.968 * * * \\
(0.042)\end{array}$ & $\begin{array}{c}-0.960 * * * \\
(0.070)\end{array}$ & $\begin{array}{c}-0.968 * * * \\
(0.070)\end{array}$ & $\begin{array}{c}-0.960 * * * \\
(0.039)\end{array}$ \\
\hline Lagged valuation premium of LETF & $\begin{array}{c}-0.648 * * * \\
(0.079)\end{array}$ & $\begin{array}{c}-0.508^{* * *} \\
(0.072)\end{array}$ & $\begin{array}{l}-0.499 * * * \\
(0.072)\end{array}$ & $\begin{array}{c}-0.629 * * * \\
(0.076)\end{array}$ & $\begin{array}{c}-0.350^{* * * *} \\
(0.070)\end{array}$ & $\begin{array}{c}-0.315^{* * *} \\
(0.073)\end{array}$ & $\begin{array}{c}-0.315^{* * *} \\
(0.073)\end{array}$ & $\begin{array}{c}-0.350^{* * * *} \\
(0.070)\end{array}$ \\
\hline $\begin{array}{l}\text { Lagged valuation premium of }(1 \times) \\
\text { fund }\end{array}$ & $\begin{array}{l}0.893 * * * \\
(0.067)\end{array}$ & $\begin{array}{c}0.370^{* * *} \\
(0.087)\end{array}$ & $\begin{array}{l}0.360^{* * *} \\
(0.086)\end{array}$ & $\begin{array}{c}0.888^{* * *} \\
(0.065)\end{array}$ & $\begin{array}{c}-0.625 * * * \\
(0.052)\end{array}$ & $\begin{array}{c}-0.274^{* * * *} \\
(0.091)\end{array}$ & $\begin{array}{c}-0.323 * * * \\
(0.093)\end{array}$ & $\begin{array}{c}-0.643^{* * *} \\
(0.054)\end{array}$ \\
\hline Lagged total deviation of LETF & $\begin{array}{l}-0.095 * * * \\
(0.017)\end{array}$ & $\begin{array}{c}-0.193 * * * \\
(0.022)\end{array}$ & $\begin{array}{l}-0.193^{* * *} \\
(0.022)\end{array}$ & $\begin{array}{c}-0.098 * * * \\
(0.017)\end{array}$ & $\begin{array}{c}-0.116^{* * * *} \\
(0.020)\end{array}$ & $\begin{array}{c}-0.147 * * * * \\
(0.034)\end{array}$ & $\begin{array}{c}-0.143^{* * *} \\
(0.034)\end{array}$ & $\begin{array}{c}-0.114 * * * \\
(0.020)\end{array}$ \\
\hline $\begin{array}{l}\text { SPX index return x No-overlapping } \\
\text { indicator }\end{array}$ & & $\begin{array}{l}-0.425^{* * *} \\
(0.068)\end{array}$ & $\begin{array}{l}-0.419^{* * *} \\
(0.068)\end{array}$ & & & $\begin{array}{c}0.467 * * * \\
(0.096)\end{array}$ & $\begin{array}{l}0.466^{* * *} \\
(0.097)\end{array}$ & \\
\hline $\begin{array}{l}\text { Underlying index return } \mathrm{x} \text { No- } \\
\text { overlapping indicator }\end{array}$ & & $\begin{array}{c}-0.133^{* *} \\
(0.067)\end{array}$ & $\begin{array}{l}-0.141 * * \\
(0.064)\end{array}$ & & & $\begin{array}{c}0.295 * * * \\
(0.093)\end{array}$ & $\begin{array}{c}0.335^{* * *} \\
(0.084)\end{array}$ & \\
\hline $\begin{array}{l}\text { Lagged valuation premium of LETF } x \\
\text { No-overlapping indicator }\end{array}$ & & $\begin{array}{l}-0.347^{*} \\
(0.185)\end{array}$ & $\begin{array}{l}-0.328^{*} \\
(0.176)\end{array}$ & & & $\begin{array}{c}-0.505^{* * *} \\
(0.119)\end{array}$ & $\begin{array}{c}-0.531 * * * \\
(0.120)\end{array}$ & \\
\hline $\begin{array}{l}\text { Lagged valuation premium of }(1 \times) \\
\text { fund } x \text { No-overlapping indicator }\end{array}$ & & $\begin{array}{c}0.749 * * * \\
(0.119)\end{array}$ & $\begin{array}{l}0.760^{* * *} \\
(0.114)\end{array}$ & & & $\begin{array}{c}-0.838^{* * *} \\
(0.110)\end{array}$ & $\begin{array}{c}-0.831^{* * *} \\
(0.110)\end{array}$ & \\
\hline $\begin{array}{l}\text { Lagged total deviation of LETF } \times \text { No- } \\
\text { overlapping indicator }\end{array}$ & & $\begin{array}{c}0.126 * * * \\
(0.030)\end{array}$ & $\begin{array}{l}0.123 * * * \\
(0.029)\end{array}$ & & & $\begin{array}{l}0.093 * * \\
(0.039)\end{array}$ & $\begin{array}{c}0.092 * * \\
(0.039)\end{array}$ & \\
\hline No-overlapping indicator & & $\begin{array}{c}0.006 \\
(0.054)\end{array}$ & $\begin{array}{c}0.053 \\
(0.055)\end{array}$ & & & $\begin{array}{c}-0.096 \\
(0.072)\end{array}$ & $\begin{array}{c}-0.164 * * \\
(0.070)\end{array}$ & \\
\hline Holding-period LIBOR interest & & & $\begin{array}{r}2.348 \\
(8.794)\end{array}$ & $\begin{array}{r}6.766 \\
(8.753)\end{array}$ & & & $\begin{array}{l}-33.815 \\
(31.243)\end{array}$ & $\begin{array}{l}-30.680 \\
(32.497)\end{array}$ \\
\hline VIX & & & $\begin{array}{c}-0.004 \\
(0.005)\end{array}$ & $\begin{array}{c}-0.005 \\
(0.005)\end{array}$ & & & $\begin{array}{c}0.001 \\
(0.007)\end{array}$ & $\begin{array}{c}-0.001 \\
(0.007)\end{array}$ \\
\hline Turnover of $(1 \times)$ fund & & & $\begin{array}{c}-1.519 * * \\
(0.653)\end{array}$ & $\begin{array}{c}-1.568^{* *} \\
(0.646)\end{array}$ & & & $\begin{array}{l}-1.089 \\
(0.949)\end{array}$ & $\begin{array}{r}-0.896 \\
(1.000)\end{array}$ \\
\hline Net fund flow of $(1 \times)$ fund & & & $\begin{array}{c}-0.084 * * \\
(0.042)\end{array}$ & $\begin{array}{l}-0.065 \\
(0.042)\end{array}$ & & & $\begin{array}{c}0.053 \\
(0.048)\end{array}$ & $\begin{array}{c}0.022 \\
(0.049)\end{array}$ \\
\hline Turnover of LETF & & & $\begin{array}{c}-0.082 \\
(0.098)\end{array}$ & $\begin{array}{c}-0.065 \\
(0.106)\end{array}$ & & & $\begin{array}{c}1.934^{* *} \\
(0.789)\end{array}$ & $\begin{array}{l}1.490^{*} \\
(0.784)\end{array}$ \\
\hline Net fund flow of LETF & & & $\begin{array}{c}-0.005 \\
(0.008)\end{array}$ & $\begin{array}{l}-0.010 \\
(0.009)\end{array}$ & & & $\begin{array}{c}-0.003 \\
(0.016)\end{array}$ & $\begin{array}{c}-0.005 \\
(0.016)\end{array}$ \\
\hline Change in LIBOR rate & & & $\begin{array}{c}1.369 \\
(2.225)\end{array}$ & $\begin{array}{c}0.785 \\
(2.292)\end{array}$ & & & $\begin{array}{c}-9.229 \\
(9.496)\end{array}$ & $\begin{array}{c}-5.150 \\
(10.121)\end{array}$ \\
\hline Constant & $\begin{array}{c}-0.063 * * \\
(0.027)\end{array}$ & $\begin{array}{c}-0.031 \\
(0.036)\end{array}$ & $\begin{array}{l}0.209^{*} \\
(0.127)\end{array}$ & $\begin{array}{c}0.204 \\
(0.127)\end{array}$ & $\begin{array}{c}-0.004 \\
(0.035)\end{array}$ & $\begin{array}{c}-0.002 \\
(0.062)\end{array}$ & $\begin{array}{c}0.054 \\
(0.164)\end{array}$ & $\begin{array}{c}0.058 \\
(0.167)\end{array}$ \\
\hline Observations & 4,522 & 4,522 & 4,518 & 4,518 & 3,081 & 3,081 & 3,079 & 3,079 \\
\hline R-squared & 0.779 & 0.794 & 0.796 & 0.781 & 0.554 & 0.583 & 0.587 & 0.556 \\
\hline
\end{tabular}


Table 7: Cumulative Effect of Various Components of Return Deviations for International LETFs

This table shows the mean of various components of the cumulative return deviations over different number of holding days on a rolling basis for international LETFs. The last observation ends on May 31, 2012. See Appendix A for variable definitions. All figures are in $\%$. Newey-West standard errors in parentheses; *** $\mathrm{p}<1 \%$, ** $\mathrm{p}<5 \%$, * $\mathrm{p}<10 \%$.

Panel A: Cumulative Effect of Various Components of LETF Return Deviations for for countries without overlaping trading hours

\begin{tabular}{|c|c|c|c|c|c|c|c|c|}
\hline \multirow[b]{2}{*}{ Number of holding days } & \multicolumn{2}{|c|}{$(-2 x)$ China Fund } & \multicolumn{2}{|c|}{ (2x) China Fund } & \multicolumn{2}{|c|}{ (-2x) Japan Fund } & \multicolumn{2}{|c|}{ (2x) Japan Fund } \\
\hline & 4-day & 21-day & 4-day & 21-day & 4-day & 21-day & 4-day & 21-day \\
\hline \multirow{2}{*}{ Total deviation of LETF } & $-0.466^{* *}$ & $-3.486 * * *$ & -0.012 & -0.215 & $-0.357 * *$ & $-2.094 * *$ & 0.163 & 0.693 \\
\hline & (0.199) & (1.079) & $(0.130)$ & $(0.196)$ & $(0.181)$ & $(0.904)$ & $(0.172)$ & $(0.660)$ \\
\hline \multirow{2}{*}{ Currency deviation of LETF } & -0.004 & -0.013 & 0.001 & 0.000 & -0.212 & $-1.073 *$ & 0.218 & 1.005 \\
\hline & $(0.007)$ & $(0.032)$ & $(0.010)$ & $(0.040)$ & $(0.135)$ & (0.639) & $(0.141)$ & $(0.661)$ \\
\hline \multirow[t]{2}{*}{ Discovery deviation of LETF } & -0.001 & 0.117 & -0.031 & -0.166 & 0.015 & 0.085 & -0.023 & -0.103 \\
\hline & $(0.170)$ & $(0.188)$ & $(0.131)$ & $(0.178)$ & $(0.1$ & $(0.1-1)$ & $(0.114)$ & $(0.131)$ \\
\hline \multirow[t]{2}{*}{ Compounding deviation } & $-0.340 * * *$ & $-3.064 * * *$ & -0.010 & $-0.207 * * *$ & $-0.129 * * *$ & $-0.965 * *$ & $-0.009 * *$ & $-0.090 * * *$ \\
\hline & $(0.086)$ & $(1.042)$ & $(0.008)$ & $(0.055)$ & $(0.041)$ & $(0.413)$ & $(0.005)$ & $(0.029)$ \\
\hline \multirow[t]{2}{*}{ NAV deviation of LETF } & $-0.100 * * *$ & $-0.517 * * *$ & $0.032 * * *$ & $0.167 * * *$ & $-0.023^{* *}$ & $-0.136^{* *}$ & $-0.021^{* * *}$ & $-0.115^{* * *}$ \\
\hline & $(0.018)$ & $(0.046)$ & $(0.005)$ & $(0.011)$ & $(0.010)$ & $(0.054)$ & $(0.007)$ & $(0.011)$ \\
\hline \multirow[t]{2}{*}{ Inefficiency deviation of LETF } & -0.021 & -0.010 & -0.003 & -0.009 & -0.007 & -0.006 & -0.002 & -0.005 \\
\hline & $(0.033)$ & $(0.030)$ & $(0.011)$ & $(0.015)$ & $(0.025)$ & $(0.021)$ & $(0.037)$ & $(0.040)$ \\
\hline \multirow[t]{2}{*}{ Tracking-error deviation of LETF } & $-0.121^{* * *}$ & $-0.527 * * *$ & $0.029 * * *$ & $0.158 * * *$ & -0.031 & $-0.142 * *$ & -0.023 & $-0.120 * * *$ \\
\hline & $(0.031)$ & $(0.059)$ & $(0.011)$ & $(0.017)$ & $(0.023)$ & $(0.057)$ & $(0.037)$ & $(0.040)$ \\
\hline \multirow{2}{*}{ Misperception deviation of LETF } & $-0.345^{*}$ & $-2.959 * * *$ & -0.041 & $-0.372 *$ & $-0.326 *$ & $-1.952 * *$ & 0.185 & 0.813 \\
\hline & $(0.203)$ & $(1.080)$ & $(0.132)$ & & $(0.181)$ & & $(0.172)$ & $(0.659)$ \\
\hline Number of observations & 1,144 & 1,127 & 751 & 734 & 1,144 & 1,127 & 750 & 733 \\
\hline
\end{tabular}

Panel B: Cumulative Effect of Various Components of LETF Return Deviations for for countries/regions with overlaping trading hours

\begin{tabular}{|c|c|c|c|c|c|c|c|c|c|c|c|c|}
\hline \multirow[b]{2}{*}{ Number of holding days } & \multicolumn{2}{|c|}{ (-2x) Brazil Fund } & \multicolumn{2}{|c|}{ (2x) Brazil Fund } & \multicolumn{2}{|c|}{ (-2x) Mexico Fund } & \multicolumn{2}{|c|}{ (2x) Mexico Fund } & \multicolumn{2}{|c|}{ (-2x) Europe Fund } & \multicolumn{2}{|c|}{ (2x) Europe Fund } \\
\hline & 4-day & 21-day & 4-day & 21-day & 4-day & 21-day & 4-day & 21-day & 4-day & 21-day & 4-day & 21-day \\
\hline \multirow[t]{2}{*}{ Total deviation of LETF } & -0.002 & -0.247 & -0.035 & -0.312 & -0.150 & $-1.169 * * *$ & 0.065 & & -0.107 & & -0.075 & -0.137 \\
\hline & $(0.074)$ & $(0.329)$ & $(0.083)$ & $(0.257)$ & $(0.095)$ & $(0.238)$ & $(0.319)$ & $(0.422)$ & $(0.191)$ & $(0.872)$ & $(0.239)$ & (1.129) \\
\hline \multirow[t]{2}{*}{ Currency deviation of LETF } & -0.000 & 0.000 & 0.000 & -0 & 0.0 & 0 & -0 & 0.000 & 0.0 & 0. & -0 . & 0.302 \\
\hline & $(0.000)$ & $(0$. & $(0.0$ & $(0$ & $(0$. & $(0$ & $(0$. & $(0$. & & & & 7) \\
\hline \multirow[t]{2}{*}{ Discovery deviation of LETF } & 0.021 & 0.131 & -0.016 & -0.091 & -0.066 & $-0.355 * * *$ & 0.0 & $0.320 * * *$ & 0.00 & 0.0 & 0.0 & -0.034 \\
\hline & $(0.067)$ & $(0.176)$ & $(0.080)$ & $(0.209)$ & $(0.053)$ & & $(0.0$ & & $(0.0$ & & & \\
\hline \multirow[t]{2}{*}{ Compounding deviation } & 0.005 & -0.231 & 0.003 & -0.102 & -0.019 & $-0.458 * *$ & -0.013 & $-0.211 * * *$ & $-0.094 * * *$ & $-0.969 * * *$ & $-0.037 * * *$ & $-0.381 * * *$ \\
\hline & $(0.028)$ & $(0.283)$ & $(0.011)$ & $(0.101)$ & $(0.023)$ & $(0.222)$ & $(0.009)$ & $(0.074)$ & $(0.032)$ & $(0.265)$ & $(0.014)$ & $(0.088)$ \\
\hline \multirow[t]{2}{*}{ NAV deviation of LETF } & $-0.028 * * *$ & $-0.147 * * *$ & $-0.025 * * *$ & $-0.129 * * *$ & $-0.064 * * *$ & $-0.329 * * *$ & -0.005 & -0.018 & $-0.099 * * *$ & $-0.517 * * *$ & -0.001 & -0.003 \\
\hline & $(0.006)$ & & $(0.005)$ & & $(0.006)$ & & & & & & & 3) \\
\hline \multirow[t]{2}{*}{ Inefficiency deviation of LETF } & 0.000 & 0.001 & 0.005 & 0.010 & -0.001 & -0.027 & 0.015 & 0.401 & 0.000 & 0.000 & -0.010 & -0.020 \\
\hline & $(0.018)$ & $(0.014)$ & $(0.030)$ & $(0.025)$ & $(0.085)$ & $(0.077)$ & $(0.325)$ & & $(0.023)$ & & & \\
\hline \multirow[t]{2}{*}{ Tracking-error deviation of LETF } & -0.028 & $-0.146 * * *$ & -0.021 & $-0.119 * * *$ & -0.065 & $-0.356 * * *$ & 0.010 & 0.382 & $-0.099 * * *$ & $-0.517 * * *$ & -0.011 & -0.023 \\
\hline & $(0.018)$ & $(0.018)$ & $(0.030)$ & $(0.022)$ & $(0.085)$ & $(0.077)$ & $(0.325)$ & $(0.405)$ & $(0.023)$ & & $(0.071)$ & $(0.083)$ \\
\hline \multirow[t]{2}{*}{ Misperception deviation of LETF } & 0.026 & -0.100 & -0.014 & -0.194 & -0.085 & $-0.813 * * *$ & 0.055 & 0.109 & -0.008 & -0.548 & -0.064 & -0.113 \\
\hline & $(0.073)$ & & & & & & & & & & & \\
\hline Number of observations & 740 & 723 & 524 & 507 & 741 & 724 & 523 & 506 & 741 & 724 & 523 & 506 \\
\hline
\end{tabular}




\section{Table 8: Determinants of the Compounding Return Deviations for International LETFs}

This table presents determinants of the compounding return deviation over holding periods of 4 and 21 trading days using OLS regressions for the international LETFs. The dependent variable is the compounding return deviation over the holding period on a non-rolling basis. Robust standard errors in parentheses; $* * * \mathrm{p}<1 \%, * * \mathrm{p}<5 \%, * \mathrm{p}<10 \%$.

Panel A: Determinants of LETF compounding deviation for the countries without overlaping trading hours

\begin{tabular}{|c|c|c|c|c|c|c|c|c|}
\hline \multirow[b]{3}{*}{ Number of holding days } & \multicolumn{8}{|c|}{ Dep. Var. = Compounding Deviation } \\
\hline & \multicolumn{2}{|c|}{$(-2 x)$ China fund } & \multicolumn{2}{|c|}{ (2x) China fund } & \multicolumn{2}{|c|}{ (-2x) Japan fund } & \multicolumn{2}{|c|}{ (2x) Japan fund } \\
\hline & $\frac{\text { 4-day }}{(1)}$ & $\frac{21-\text { day }}{(2)}$ & $\frac{4-\text { day }}{(3)}$ & $\frac{21-\text { day }}{(4)}$ & $\frac{4 \text {-day }}{(5)}$ & $\frac{21 \text {-day }}{(6)}$ & $\frac{\text { 4-day }}{(7)}$ & $\frac{21 \text {-day }}{(8)}$ \\
\hline $\begin{array}{l}\text { Variance of }(1 \mathrm{x}) \text { fund daily returns } \\
\text { during the holding period }\end{array}$ & $\begin{array}{c}-0.093 * * * \\
(0.004)\end{array}$ & $\begin{array}{c}-0.490 * * * \\
(0.022)\end{array}$ & $\begin{array}{c}-0.030 * * * \\
(0.001)\end{array}$ & $\begin{array}{c}-0.202 * * * \\
(0.018)\end{array}$ & $\begin{array}{c}-0.094 * * * \\
(0.001)\end{array}$ & $\begin{array}{c}-0.474 * * * \\
(0.023)\end{array}$ & $\begin{array}{c}-0.030 * * * \\
(0.001)\end{array}$ & $\begin{array}{c}-0.182 * * * \\
(0.004)\end{array}$ \\
\hline $\begin{array}{l}\text { Square of cumulative }(1 \mathrm{x}) \text { fund return } \\
\text { during the holding period }\end{array}$ & $\begin{array}{l}0.022 * * * \\
(0.001)\end{array}$ & $\begin{array}{c}0.018^{* * *} \\
(0.006)\end{array}$ & $\begin{array}{l}0.008^{* * *} \\
(0.000)\end{array}$ & $\begin{array}{c}0.010^{* * *} \\
(0.001)\end{array}$ & $\begin{array}{l}0.023 * * * \\
(0.001)\end{array}$ & $\begin{array}{c}0.033^{* * *} \\
(0.001)\end{array}$ & $\begin{array}{l}0.008 * * * \\
(0.000)\end{array}$ & $\begin{array}{c}0.010^{* * *} \\
(0.000)\end{array}$ \\
\hline Constant & $\begin{array}{c}0.033 \\
(0.028)\end{array}$ & $\begin{array}{l}-0.082 \\
(0.327)\end{array}$ & $\begin{array}{l}-0.002 \\
(0.002)\end{array}$ & $\begin{array}{l}-0.006 \\
(0.053)\end{array}$ & $\begin{array}{c}0.006 \\
(0.004)\end{array}$ & $\begin{array}{c}-0.397 * * * \\
(0.056)\end{array}$ & $\begin{array}{l}-0.001 \\
(0.001)\end{array}$ & $\begin{array}{c}-0.034 * * * \\
(0.007)\end{array}$ \\
\hline No. of observations & 286 & 54 & 188 & 35 & 286 & 54 & 188 & 35 \\
\hline R-squared & 0.982 & 0.961 & 0.997 & 0.952 & 0.998 & 0.985 & 0.998 & 0.993 \\
\hline
\end{tabular}

Panel B: Determinants of LETF compounding deviation for the countries/regions with overlaping trading hours

\begin{tabular}{|c|c|c|c|c|c|c|c|c|c|c|c|c|}
\hline \multirow[b]{3}{*}{ Number of holding days } & \multicolumn{8}{|c|}{ Dep. Var. = Compounding Deviation } & \multirow{2}{*}{\multicolumn{2}{|c|}{$(-2 x)$ Europe fund }} & \multirow{2}{*}{\multicolumn{2}{|c|}{ (2x) Europe fund }} \\
\hline & \multicolumn{2}{|c|}{$(-2 x)$ Brazil fund } & \multicolumn{2}{|c|}{ (2x) Brazil fund } & \multicolumn{2}{|c|}{$(-2 x)$ Mexico fund } & \multicolumn{2}{|c|}{ (2x) Mexico fund } & & & & \\
\hline & $\frac{4 \text {-day }}{(1)}$ & $\frac{21 \text {-day }}{(2)}$ & $\frac{4 \text {-day }}{(3)}$ & $\frac{21-\text { day }}{(4)}$ & $\frac{4 \text {-day }}{(5)}$ & $\frac{21 \text {-day }}{(6)}$ & $\frac{4 \text {-day }}{(7)}$ & $\frac{21 \text {-day }}{(8)}$ & $\frac{4 \text {-day }}{(9)}$ & $\frac{21 \text {-day }}{(10)}$ & $\frac{\text { 4-day }}{(11)}$ & $\frac{21 \text {-day }}{(12)}$ \\
\hline $\begin{array}{l}\text { Variance of }(1 \mathrm{x}) \text { fund daily returns } \\
\text { during the holding period }\end{array}$ & $\begin{array}{c}-0.093 * * * \\
(0.001)\end{array}$ & $\begin{array}{c}-0.605 * * * \\
(0.037)\end{array}$ & $\begin{array}{c}-0.029 * * * \\
(0.000)\end{array}$ & $\begin{array}{c}-0.161^{* * *} \\
(0.015)\end{array}$ & $\begin{array}{c}-0.093 * * * \\
(0.002)\end{array}$ & $\begin{array}{c}-0.629 * * * \\
(0.022)\end{array}$ & $\begin{array}{c}-0.030 * * * \\
(0.001)\end{array}$ & $\begin{array}{c}-0.165 * * * \\
(0.007)\end{array}$ & $\begin{array}{c}-0.094 * * * \\
(0.002)\end{array}$ & $\begin{array}{c}-0.631^{* * *} \\
(0.023)\end{array}$ & $\begin{array}{c}-0.029 * * * \\
(0.000)\end{array}$ & $\begin{array}{c}-0.152 * * * \\
(0.008)\end{array}$ \\
\hline $\begin{array}{l}\text { Square of cumulative }(1 \mathrm{x}) \text { fund return } \\
\text { during the holding period }\end{array}$ & $\begin{array}{c}0.023 * * * \\
(0.001)\end{array}$ & $\begin{array}{c}0.029 * * * \\
(0.002)\end{array}$ & $\begin{array}{c}0.008^{* * * *} \\
(0.000)\end{array}$ & $\begin{array}{c}0.010^{* * *} \\
(0.001)\end{array}$ & $\begin{array}{c}0.022 * * * \\
(0.000)\end{array}$ & $\begin{array}{c}0.029 * * * \\
(0.001)\end{array}$ & $\begin{array}{c}0.008^{* * *} \\
(0.000)\end{array}$ & $\begin{array}{c}0.009 * * * \\
(0.001)\end{array}$ & $\begin{array}{c}0.023^{* * * *} \\
(0.000)\end{array}$ & $\begin{array}{c}0.027 * * * \\
(0.001)\end{array}$ & $\begin{array}{c}0.008^{* * * *} \\
(0.000)\end{array}$ & $\begin{array}{c}0.008 * * * \\
(0.001)\end{array}$ \\
\hline Constant & $\begin{array}{c}0.006 \\
(0.006)\end{array}$ & $\begin{array}{c}0.009 \\
(0.106)\end{array}$ & $\begin{array}{c}-0.003 * * * \\
(0.001)\end{array}$ & $\begin{array}{c}-0.109 * * * \\
(0.035)\end{array}$ & $\begin{array}{c}0.008 * * \\
(0.004)\end{array}$ & $\begin{array}{c}0.053 \\
(0.043)\end{array}$ & $\begin{array}{c}-0.001 \\
(0.001)\end{array}$ & $\begin{array}{c}-0.043^{*} \\
(0.021)\end{array}$ & $\begin{array}{l}0.011^{* *} \\
(0.005)\end{array}$ & $\begin{array}{c}0.149 * * \\
(0.061)\end{array}$ & $\begin{array}{c}-0.005^{* * *} \\
(0.001)\end{array}$ & $\begin{array}{c}-0.071^{*} \\
(0.035)\end{array}$ \\
\hline No. of observations & 185 & 35 & 131 & 25 & 186 & 35 & 131 & 25 & 186 & 35 & 131 & 25 \\
\hline R-squared & 0.997 & 0.981 & 0.997 & 0.951 & 0.996 & 0.987 & 0.998 & 0.966 & 0.998 & 0.992 & 0.999 & 0.961 \\
\hline
\end{tabular}


Table 9: Determinants of the Cumulative Total Return Deviations for International LETFs

This table presents determinants of cumulative total return deviation over holding periods of 4 and 21 trading days using OLS regressions for the international LETFs. The dependent variable is the cumulative total return deviation over the holding period on a non-rolling basis. Robust standard errors in parentheses; $* * * \mathrm{p}<1 \%, * * \mathrm{p}<5 \%$, $* \mathrm{p}<10 \%$.

Panel A: Determinants of LETF cumulative total return deviation for the countries without overlaping trading hours

\begin{tabular}{|c|c|c|c|c|c|c|c|c|}
\hline & \multicolumn{8}{|c|}{ Dependent Variable $=$ Cumulative Total Return Deviation } \\
\hline & \multicolumn{2}{|c|}{ (-2x) China Fund } & \multicolumn{2}{|c|}{ (2x) China Fund } & \multicolumn{2}{|c|}{ (-2x) Japan Fund } & \multicolumn{2}{|c|}{ (2x) Japan Fund } \\
\hline & $\frac{4 \text {-day }}{(1)}$ & $\frac{21 \text {-day }}{(2)}$ & $\frac{4 \text {-day }}{(3)}$ & $\frac{21-\text { day }}{(4)}$ & $\frac{4 \text {-day }}{(5)}$ & $\frac{21 \text {-day }}{(6)}$ & $\frac{4 \text {-day }}{(7)}$ & $\frac{21 \text {-day }}{(8)}$ \\
\hline $\begin{array}{l}\text { Cumulative SPX index return during the } \\
\text { holding period }\end{array}$ & $\begin{array}{c}-0.745^{* * *} \\
(0.132)\end{array}$ & $\begin{array}{l}0.263 * * \\
(0.111)\end{array}$ & $\begin{array}{l}0.558 * * * \\
(0.092)\end{array}$ & $\begin{array}{c}0.174 \\
(0.108)\end{array}$ & $\begin{array}{c}-0.465 * * * \\
(0.101)\end{array}$ & $\begin{array}{c}0.483 * * * \\
(0.117)\end{array}$ & $\begin{array}{c}0.331^{* * *} \\
(0.105)\end{array}$ & $\begin{array}{l}-0.040 \\
(0.195)\end{array}$ \\
\hline $\begin{array}{l}\text { Variance of }(1 \mathrm{x}) \text { fund daily returns during the } \\
\text { holding period }\end{array}$ & $\begin{array}{c}-0.128^{* * *} \\
(0.020)\end{array}$ & $\begin{array}{c}-0.452 * * * \\
(0.053)\end{array}$ & $\begin{array}{c}0.068 \\
(0.058)\end{array}$ & $\begin{array}{l}-0.079 \\
(0.148)\end{array}$ & $\begin{array}{c}-0.232 * * * \\
(0.053)\end{array}$ & $\begin{array}{c}-0.788^{* * *} \\
(0.117)\end{array}$ & $\begin{array}{l}-0.060 \\
(0.236)\end{array}$ & $\begin{array}{l}-0.032 \\
(0.966)\end{array}$ \\
\hline $\begin{array}{l}\text { Square of cumulative }(1 \mathrm{x}) \text { fund return during } \\
\text { the holding period }\end{array}$ & $\begin{array}{l}-0.002 \\
(0.006)\end{array}$ & $\begin{array}{l}0.011^{*} \\
(0.006)\end{array}$ & $\begin{array}{c}0.018 \\
(0.011)\end{array}$ & $\begin{array}{c}0.005 \\
(0.005)\end{array}$ & $\begin{array}{l}0.026^{*} \\
(0.015)\end{array}$ & $\begin{array}{c}0.059 * * * \\
(0.007)\end{array}$ & $\begin{array}{c}0.034 \\
(0.024)\end{array}$ & $\begin{array}{c}0.024 \\
(0.044)\end{array}$ \\
\hline Holding-period LIBOR interest & $\begin{array}{c}-3.041 \\
(19.776)\end{array}$ & $\begin{array}{c}-9.453 \\
(8.460)\end{array}$ & $\begin{array}{c}-2.313 \\
(84.298)\end{array}$ & $\begin{array}{c}14.411 \\
(47.411)\end{array}$ & $\begin{array}{c}-5.856 \\
(14.244)\end{array}$ & $\begin{array}{c}2.825 \\
(9.516)\end{array}$ & $\begin{array}{c}5.268 \\
(114.128)\end{array}$ & $\begin{array}{c}72.708 \\
(154.253)\end{array}$ \\
\hline Lagged one-period cumulative total deviation & $\begin{array}{c}-0.429 * * * \\
(0.077)\end{array}$ & $\begin{array}{l}-0.197 \\
(0.129)\end{array}$ & $\begin{array}{c}-0.437 * * * \\
(0.071)\end{array}$ & $\begin{array}{l}-0.245 \\
(0.237)\end{array}$ & $\begin{array}{c}-0.343^{* * *} \\
(0.066)\end{array}$ & $\begin{array}{c}0.021 \\
(0.130)\end{array}$ & $\begin{array}{c}-0.263^{* * *} \\
(0.069)\end{array}$ & $\begin{array}{c}0.022 \\
(0.180)\end{array}$ \\
\hline Constant & $\begin{array}{c}0.694 * * \\
(0.280)\end{array}$ & $\begin{array}{l}-0.489 \\
(0.817)\end{array}$ & $\begin{array}{l}-0.556 \\
(0.475)\end{array}$ & $\begin{array}{l}-0.915 \\
(1.536)\end{array}$ & $\begin{array}{c}0.222 \\
(0.306)\end{array}$ & $\begin{array}{c}-2.162 * * \\
(1.023)\end{array}$ & $\begin{array}{l}-0.007 \\
(0.685)\end{array}$ & $\begin{array}{l}-1.981 \\
(4.290)\end{array}$ \\
\hline No. of observations & 285 & 53 & 187 & 34 & 285 & 53 & 187 & 34 \\
\hline R-squared & 0.547 & 0.776 & 0.395 & 0.145 & 0.366 & 0.534 & 0.141 & 0.021 \\
\hline
\end{tabular}

Panel B: Determinants of LETF cumulative total return deviation for the countries/regions with overlaping trading hours

\begin{tabular}{|c|c|c|c|c|c|c|c|c|c|c|c|c|}
\hline & \multicolumn{2}{|c|}{$(-2 x)$ Brazil Fund } & \multicolumn{2}{|c|}{ (2x) Brazil Fund } & \multicolumn{2}{|c|}{ (-2x) Mexico Fund } & \multicolumn{2}{|c|}{ (2x) Mexico Fund } & \multicolumn{2}{|c|}{ (-2x) Europe Fund } & \multicolumn{2}{|c|}{ (2x) Europe Fund } \\
\hline & $\frac{4-\text { day }}{(1)}$ & $\frac{21 \text {-day }}{(2)}$ & $\frac{4-\text { day }}{(3)}$ & $\frac{21 \text {-day }}{(4)}$ & $\frac{4 \text {-day }}{(5)}$ & $\frac{21 \text {-day }}{(6)}$ & $\frac{4 \text {-day }}{(7)}$ & $\frac{21 \text {-day }}{(8)}$ & $\frac{4 \text {-day }}{(9)}$ & $\frac{21 \text {-day }}{(10)}$ & $\frac{4-\text { day }}{(11)}$ & $\frac{21 \text {-day }}{(12)}$ \\
\hline $\begin{array}{l}\text { Cumulative SPX index return during the } \\
\text { holding period }\end{array}$ & $\begin{array}{c}-0.147^{* *} \\
(0.065)\end{array}$ & $\begin{array}{c}0.037 \\
(0.093)\end{array}$ & $\begin{array}{c}0.128 \\
(0.086)\end{array}$ & $\begin{array}{c}0.151 \\
(0.142)\end{array}$ & $\begin{array}{c}0.014 \\
(0.090)\end{array}$ & $\begin{array}{c}0.058 \\
(0.078)\end{array}$ & $\begin{array}{c}-0.696 * * * \\
(0.196)\end{array}$ & $\begin{array}{l}-0.291 \\
(0.267)\end{array}$ & $\begin{array}{c}-0.782 * * * \\
(0.088)\end{array}$ & $\begin{array}{l}-0.364 \\
(0.363)\end{array}$ & $\begin{array}{l}0.815^{* * * *} \\
(0.148)\end{array}$ & $\begin{array}{c}1.463^{* * * *} \\
(0.317)\end{array}$ \\
\hline $\begin{array}{l}\text { Variance of }(1 \mathrm{x}) \text { fund daily returns during the } \\
\text { holding period }\end{array}$ & $\begin{array}{c}-0.094 * * * \\
(0.027)\end{array}$ & $\begin{array}{c}-0.674 * * * \\
(0.157)\end{array}$ & $\begin{array}{l}-0.037 \\
(0.050)\end{array}$ & $\begin{array}{c}-0.428 * * \\
(0.152)\end{array}$ & $\begin{array}{c}-0.127 * * * \\
(0.043)\end{array}$ & $\begin{array}{c}-0.602^{* * *} \\
(0.160)\end{array}$ & $\begin{array}{c}-0.229 * * * \\
(0.047)\end{array}$ & $\begin{array}{l}-0.532 \\
(0.422)\end{array}$ & $\begin{array}{c}-0.135^{* *} \\
(0.069)\end{array}$ & $\begin{array}{l}-0.538 \\
(0.435)\end{array}$ & $\begin{array}{l}0.015 \\
(0.018)\end{array}$ & $\begin{array}{c}0.404 \\
(0.414)\end{array}$ \\
\hline $\begin{array}{l}\text { Square of cumulative }(1 \mathrm{x}) \text { fund return during } \\
\text { the holding period }\end{array}$ & $\begin{array}{c}0.028 * * * \\
(0.006)\end{array}$ & $\begin{array}{c}0.028 * * * \\
(0.005)\end{array}$ & $\begin{array}{c}0.013 \\
(0.009)\end{array}$ & $\begin{array}{l}0.034^{* *} \\
(0.013)\end{array}$ & & $\begin{array}{c}0.037 * * * \\
(0.010)\end{array}$ & & $\begin{array}{c}0.002 \\
(0.025)\end{array}$ & $\begin{array}{l}0.029 * \\
(0.016)\end{array}$ & & & \\
\hline BOR interest & $\begin{array}{c}1.437 \\
(54.778)\end{array}$ & $\begin{array}{c}19.408 \\
(47.497)\end{array}$ & $\begin{array}{c}4.147 \\
(74.793)\end{array}$ & $\begin{array}{l}-118.010 \\
(84.177)\end{array}$ & $\begin{array}{l}-14.539 \\
(85.589)\end{array}$ & $\begin{array}{c}5.367 \\
(53.954)\end{array}$ & $\begin{array}{c}146.894 \\
(159.754)\end{array}$ & $\begin{array}{c}46.373 \\
(106.207)\end{array}$ & $\begin{array}{c}9.965 \\
(120.193)\end{array}$ & $\begin{array}{c}-7.403 \\
(125.414)\end{array}$ & $\begin{array}{c}-263.674 * * \\
(130.799)\end{array}$ & $\begin{array}{l}-181.540 \\
(145.480)\end{array}$ \\
\hline Lagged one-period cumulative total deviation & $\begin{array}{c}-0.395 * * * \\
(0.093)\end{array}$ & $\begin{array}{c}-0.226^{* *} \\
(0.096)\end{array}$ & $\begin{array}{c}-0.387 * * * \\
(0.127)\end{array}$ & $\begin{array}{l}-0.382^{*} \\
(0.188)\end{array}$ & $\begin{array}{c}-0.419 * * * \\
(0.093)\end{array}$ & $\begin{array}{c}-0.651^{* * * *} \\
(0.152)\end{array}$ & $\begin{array}{c}-0.477 * * * \\
(0.147)\end{array}$ & $\begin{array}{l}-0.270 \\
(0.316)\end{array}$ & $\begin{array}{c}-0.177 * * * \\
(0.059)\end{array}$ & $\begin{array}{c}0.024 \\
(0.148)\end{array}$ & $\begin{array}{c}-0.188^{* *} \\
(0.082)\end{array}$ & $\begin{array}{l}-0.060 \\
(0.106)\end{array}$ \\
\hline Constant & $\begin{array}{l}-0.060 \\
(0.343)\end{array}$ & $\begin{array}{l}-0.407 \\
(1.674)\end{array}$ & $\begin{array}{l}-0.122 \\
(0.505)\end{array}$ & $\begin{array}{c}2.899 \\
(2.434)\end{array}$ & $\begin{array}{c}0.052 \\
(0.456)\end{array}$ & $\begin{array}{l}-2.122 \\
(1.734)\end{array}$ & $\begin{array}{l}-0.006 \\
(0.899)\end{array}$ & $\begin{array}{c}0.063 \\
(3.292)\end{array}$ & $\begin{array}{c}0.192 \\
(0.758)\end{array}$ & $\begin{array}{c}0.184 \\
(3.262)\end{array}$ & $\begin{array}{l}1.517^{*} \\
(0.899)\end{array}$ & $\begin{array}{c}2.001 \\
(5.615)\end{array}$ \\
\hline No. o & 184 & 34 & 130 & 24 & 185 & 34 & 130 & 24 & 185 & 34 & 130 & 24 \\
\hline R-squared & 0.312 & 0.668 & 0.192 & 0.550 & 0.232 & 0.622 & 0.394 & 0.238 & 0.309 & 0.184 & 0.304 & 0.595 \\
\hline
\end{tabular}

Panel C: Determinants of LETF cumulative total return deviation of pooled sample across countries

\begin{tabular}{|c|c|c|c|c|c|c|c|c|}
\hline \multirow{3}{*}{ Target multiple } & \multicolumn{4}{|c|}{ 4-day } & \multicolumn{4}{|c|}{ 21-day } \\
\hline & \multicolumn{2}{|c|}{ (-2x) Funds } & \multicolumn{2}{|c|}{ (2x) Funds } & \multicolumn{2}{|c|}{ (-2x) Funds } & \multicolumn{2}{|c|}{ (2x) Funds } \\
\hline & (1) & (2) & (3) & (4) & (5) & (6) & (7) & (8) \\
\hline $\begin{array}{l}\text { Lumulative SPX index return during the } \\
\text { olding period }\end{array}$ & $\begin{array}{l}-0.530 * * * \\
(0.056)\end{array}$ & $\begin{array}{c}-0.324 * * * \\
(0.054)\end{array}$ & $\begin{array}{c}0.236 * * * \\
(0.066)\end{array}$ & $\begin{array}{c}0.050 \\
(0.092)\end{array}$ & $\begin{array}{l}0.203^{* *} \\
(0.084)\end{array}$ & $\begin{array}{c}0.039 \\
(0.098)\end{array}$ & $\begin{array}{l}-0.145 \\
(0.109)\end{array}$ & $\begin{array}{c}0.002 \\
(0.195)\end{array}$ \\
\hline $\begin{array}{l}\text { Variance of }(1 \mathrm{x}) \text { fund daily returns during the } \\
\text { holding period }\end{array}$ & $\begin{array}{l}-0.140 * * * \\
(0.021)\end{array}$ & $\begin{array}{c}-0.097 * * * \\
(0.024)\end{array}$ & $\begin{array}{l}-0.007 \\
(0.031)\end{array}$ & $\begin{array}{l}-0.033 \\
(0.033)\end{array}$ & $\begin{array}{c}-0.461 * * * \\
(0.070)\end{array}$ & $\begin{array}{r}-0.320^{*} \\
(0.190)\end{array}$ & $\begin{array}{c}-0.441^{* *} \\
(0.196)\end{array}$ & $\begin{array}{c}-0.454 * * \\
(0.221)\end{array}$ \\
\hline $\begin{array}{l}\text { Square of cumulative ( } 1 \mathrm{x}) \text { fund return during } \\
\text { he holding period }\end{array}$ & $\begin{array}{c}0.004 \\
(0.006)\end{array}$ & $\begin{array}{c}0.023^{* * * *} \\
(0.008)\end{array}$ & $\begin{array}{l}-0.006 \\
(0.009)\end{array}$ & $\begin{array}{l}-0.011 \\
(0.013)\end{array}$ & $\begin{array}{c}0.026 * * * \\
(0.007)\end{array}$ & $\begin{array}{c}0.022 \\
(0.013)\end{array}$ & $\begin{array}{c}0.008 \\
(0.010)\end{array}$ & $\begin{array}{l}0.027^{*} \\
(0.015)\end{array}$ \\
\hline Holding-period LIBOR interest & $\begin{array}{c}-7.670 \\
(11.183)\end{array}$ & $\begin{array}{c}18.894 \\
(52.542)\end{array}$ & $\begin{array}{c}49.233 \\
(59.617)\end{array}$ & $\begin{array}{c}81.837 \\
(82.562)\end{array}$ & $\begin{array}{l}-6.919 \\
(5.848)\end{array}$ & $\begin{array}{c}-7.703 \\
(52.280)\end{array}$ & $\begin{array}{c}-8.930 \\
(41.729)\end{array}$ & $\begin{array}{c}-8.902 \\
(67.528)\end{array}$ \\
\hline $\begin{array}{l}\text { Lagged one-period cumulative total deviation } \\
\text { of LETF }\end{array}$ & $\begin{array}{c}-0.388 * * * \\
(0.040)\end{array}$ & $\begin{array}{c}-0.325 * * * \\
(0.051)\end{array}$ & $\begin{array}{c}-0.329 * * * \\
(0.054)\end{array}$ & $\begin{array}{c}-0.260 * * * \\
(0.090)\end{array}$ & $\begin{array}{l}-0.039 \\
(0.071)\end{array}$ & $\begin{array}{l}-0.012 \\
(0.092)\end{array}$ & $\begin{array}{c}-0.238 * * * \\
(0.088)\end{array}$ & $\begin{array}{l}-0.169 \\
(0.125)\end{array}$ \\
\hline $\begin{array}{l}\text { Cumulative SPX index return x No- } \\
\text { overlapping indicator }\end{array}$ & & $\begin{array}{c}-0.289 * * * \\
(0.096)\end{array}$ & & $\begin{array}{c}0.399 * * * \\
(0.128)\end{array}$ & & $\begin{array}{l}0.259^{*} \\
(0.145)\end{array}$ & & $\begin{array}{l}-0.197 \\
(0.242)\end{array}$ \\
\hline $\begin{array}{l}\text { Variance of }(1 \mathrm{x}) \text { fund daily returns during the } \\
\text { holding period } \mathrm{x} \text { No-overlapping indicator }\end{array}$ & & $\begin{array}{l}-0.045 \\
(0.033)\end{array}$ & & $\begin{array}{c}0.063 \\
(0.101)\end{array}$ & & $\begin{array}{l}-0.161 \\
(0.206)\end{array}$ & & $\begin{array}{c}0.108 \\
(0.451)\end{array}$ \\
\hline $\begin{array}{l}\text { Square of cumulative }(1 \mathrm{x}) \text { fund return x No- } \\
\text { overlapping indicator }\end{array}$ & & $\begin{array}{c}-0.021 * * \\
(0.010)\end{array}$ & & $\begin{array}{c}0.012 \\
(0.019)\end{array}$ & & $\begin{array}{c}0.006 \\
(0.016)\end{array}$ & & $\begin{array}{l}-0.038 \\
(0.023)\end{array}$ \\
\hline $\begin{array}{l}\text { Holding-period LIBOR interest x No- } \\
\text { overlapping indicator }\end{array}$ & & $\begin{array}{l}-26.369 \\
(53.891)\end{array}$ & & $\begin{array}{c}-45.050 \\
(118.487)\end{array}$ & & $\begin{array}{c}3.913 \\
(52.667)\end{array}$ & & $\begin{array}{c}-2.034 \\
(87.022)\end{array}$ \\
\hline $\begin{array}{l}\text { Lagged cumulative total deviation x No- } \\
\text { overlapping indicator }\end{array}$ & & $\begin{array}{l}-0.076 \\
(0.070)\end{array}$ & & $\begin{array}{l}-0.149 \\
(0.107)\end{array}$ & & $\begin{array}{l}-0.048 \\
(0.129)\end{array}$ & & $\begin{array}{l}-0.077 \\
(0.178)\end{array}$ \\
\hline No-overlapping indicator & & $\begin{array}{c}0.566 \\
(0.385)\end{array}$ & & $\begin{array}{l}-0.060 \\
(0.725)\end{array}$ & & $\begin{array}{l}-0.556 \\
(1.857)\end{array}$ & & $\begin{array}{c}0.825 \\
(3.065)\end{array}$ \\
\hline Constant & $\begin{array}{c}0.452^{* * *} \\
(0.143)\end{array}$ & $\begin{array}{l}-0.098 \\
(0.317)\end{array}$ & $\begin{array}{l}-0.179 \\
(0.361)\end{array}$ & $\begin{array}{l}-0.226 \\
(0.523)\end{array}$ & $\begin{array}{l}-0.855^{*} \\
(0.450)\end{array}$ & $\begin{array}{l}-0.782 \\
(1.735)\end{array}$ & $\begin{array}{c}1.544 \\
(1.481)\end{array}$ & $\begin{array}{c}1.026 \\
(2.242)\end{array}$ \\
\hline No. of observations & 1,122 & 1,122 & 760 & 760 & 205 & 205 & 137 & 137 \\
\hline -squared & 0.399 & 0.410 & 0.132 & 0.154 & 0.485 & 0.497 & 0.092 & 0.110 \\
\hline
\end{tabular}


Table 10: Return Correlations between ILETFs and Related Indices over Various Holding Periods

This table presents the pair-wise correlations between the total cumulative returns of international LETFs and those of related indices over 1, 4, and 21 holding days. The ending date for our sample is May 31, 2012. We use Shanghai Composite Index (Bloomberg symbol: shcomp) to measure the foreign market return for China, Nikkei 225 Index (nky) for Japan, Bovespa Brasil Sao Paulo Stock Exchange Index (ibov) for Brazil, Mexican Bolsa Ipc Index (mexbol) for Mexico, and FTSEurofirst 300 Index (e300) for Europe. The observations are on a rolling basis so that an observation can start from any trading day. The results from the non-rolling basis are consistent. See Appendix A for variable definitions and Appendix B for details on the names and specifications on the regular and leveraged ETFs.

Panel A: Return correlations between LETFs and indices for the countries without overlapping trading hours

\begin{tabular}{l|ccc|ccc|ccc}
\hline & \multicolumn{3}{|c}{ Foreign market return } & \multicolumn{5}{c|}{ SPX return } & \multicolumn{5}{c}{ Underlying index return } \\
& 1-day & 4-day & 21-day & 1-day & 4-day & 21-day & 1-day & 4-day & 21-day \\
\hline China & & & & & & & & & \\
(1x) fund return & 0.27 & 0.40 & 0.56 & 0.83 & 0.79 & 0.75 & 0.50 & 0.83 & 0.96 \\
(-2x) fund return & -0.26 & -0.41 & -0.51 & -0.83 & -0.76 & -0.56 & -0.49 & -0.81 & -0.85 \\
(2x) fund return & 0.36 & 0.52 & 0.61 & 0.80 & 0.78 & 0.69 & 0.54 & 0.88 & 0.97 \\
\hline Japan & & & & & & & & & \\
(1x) fund return & 0.27 & 0.69 & 0.85 & 0.82 & 0.79 & 0.84 & 0.30 & 0.72 & 0.86 \\
(-2x) fund return & -0.29 & -0.68 & -0.78 & -0.82 & -0.78 & -0.76 & -0.32 & -0.71 & -0.79 \\
(2x) fund return & 0.30 & 0.70 & 0.84 & 0.68 & 0.68 & 0.71 & 0.34 & 0.74 & 0.87 \\
\hline
\end{tabular}

Panel B: Return correlations between LETFs and indices for the countries/regions with overlapping trading hours

\begin{tabular}{|c|c|c|c|c|c|c|c|c|c|}
\hline & \multicolumn{3}{|c|}{$\underline{\text { Foreign market return }}$} & \multicolumn{3}{|c|}{$\underline{\text { SPX return }}$} & \multicolumn{3}{|c|}{ Underlying index return } \\
\hline & 1-day & 4-day & 21-day & 1-day & 4-day & 21-day & 1-day & 4-day & 21-day \\
\hline \multicolumn{10}{|l|}{ Brazil } \\
\hline (1x) fund return & 0.89 & 0.92 & 0.93 & 0.83 & 0.81 & 0.77 & 0.89 & 0.97 & 0.99 \\
\hline$(-2 x)$ fund return & -0.89 & -0.92 & -0.92 & -0.83 & -0.81 & -0.76 & -0.89 & -0.97 & -0.98 \\
\hline (2x) fund return & 0.87 & 0.91 & 0.90 & 0.83 & 0.81 & 0.72 & 0.87 & 0.97 & 0.99 \\
\hline \multicolumn{10}{|l|}{ Mexico } \\
\hline (1x) fund return & 0.89 & 0.92 & 0.91 & 0.87 & 0.86 & 0.85 & 0.88 & 0.97 & 0.99 \\
\hline$(-2 x)$ fund return & -0.80 & -0.89 & -0.90 & -0.77 & -0.82 & -0.83 & -0.81 & -0.94 & -0.98 \\
\hline$(2 x)$ fund return & 0.41 & 0.59 & 0.79 & 0.37 & 0.57 & 0.72 & 0.49 & 0.69 & 0.92 \\
\hline \multicolumn{10}{|l|}{ Europe } \\
\hline (1x) fund return & 0.76 & 0.87 & 0.87 & 0.91 & 0.90 & 0.87 & 0.75 & 0.86 & 0.87 \\
\hline$(-2 x)$ fund return & -0.76 & -0.86 & -0.85 & -0.91 & -0.89 & -0.86 & -0.75 & -0.86 & -0.85 \\
\hline (2x) fund return & 0.76 & 0.86 & 0.84 & 0.87 & 0.89 & 0.84 & 0.76 & 0.86 & 0.83 \\
\hline
\end{tabular}




\section{Appendix A: Definitions of Terms and Variables}

\begin{tabular}{|c|c|}
\hline Names & Definitions \\
\hline Actual return & $\begin{array}{l}\text { Also called the actual market return of the LETF. Refers to the return of an LETF based on the actual percentage price change, adjusted for dividend yield. All return } \\
\text { variables in this study are in percentage, unless noted otherwise. }\end{array}$ \\
\hline$(1 \mathrm{x})$ fund return & The total return (including price return and dividend yield) of the regular $(1 \mathrm{x})$ ETF tracking the underlying index traded in the U.S. during the holding period. \\
\hline Beta & Slope coefficient from regressing daily return of an LETF on the daily return of its benchmark. \\
\hline Change in LIBOR rate & The 3-month BBA U.S. Dollar LIBOR rate (Bloomberg symbol: us0003m) of the current trading day less that of the previous trading day. \\
\hline Compounding deviation & $\begin{array}{l}\text { Also called compounding effect. Cumulative target return of an LETF less the naïve expected return, which is calculated as the product between the daily multiple of an } \\
\text { LETF and the cumulative return of the benchmark of the LETF. Compounding deviation occurs only when investors hold an LETF for more than one trading day. }\end{array}$ \\
\hline $\begin{array}{l}\text { Cumulative SPX index return during } \\
\text { the holding period }\end{array}$ & Cumulative total return of SPTR index during the holding period. \\
\hline Currency Deviation & $\begin{array}{l}\text { Return deviation component due to changes in foreign exchange rate, which is calculated as the Naïve Expected Return Based on Foreign Index in USD less the Naïve } \\
\text { Expected Return Based on Foreign Index in foreign currency. }\end{array}$ \\
\hline Discovery Deviation & $\begin{array}{l}\text { A return deviation component due to price discovery of the U.S.-traded foreign index fund. It is calculated as the Naïve Expected Return based on the U.S.-traded } \\
\text { foreign index regular }(1 \mathrm{x}) \text { ETF less the Naïve Expected Return based on the underlying foreign index in USD. }\end{array}$ \\
\hline Foreign market return & $\begin{array}{l}\text { Total return of the broad market index in a foreign country. We use the Shanghai Composite Index (Bloomberg symbol: shcomp) to measure the foreign market return } \\
\text { for China, Nikkei } 225 \text { Index (nky) for Japan, Bovespa Brasil Sao Paulo Stock Exchange Index (ibov) for Brazil, Mexican Bolsa Ipc Index (mexbol) for Mexico, and } \\
\text { FTSEurofirst } 300 \text { Index (e300) for Europe. This index is not the underlying index of our sample LETFs. }\end{array}$ \\
\hline Holding-period LIBOR interest & $\begin{array}{l}\text { The LIBOR interest accumulated over the holding period. In particular, the LIBOR interest earned over one trading day is calculated using the actual number of } \\
\text { calendar days between the previous trading day and the current trading day, divided by } 360 \text {, and then multiplied by the LIBOR rate from the previous trading day. For } \\
\text { multiple holding days, this measure is accumulated over each day during the holding period. }\end{array}$ \\
\hline Index daily return & Daily return of the underlying index that an LETF is tracking. If available, this return is based on the index in foreign currency. \\
\hline Inefficiency deviation & Also called inefficiency return deviation. It is computed as actual market return of an LETF less its NAV return. \\
\hline Lagged one-period variables & $\begin{array}{l}\text { Value of the same variable in the previous holding period. For example, if a holding period has } 21 \text { trading days, this lagged variable will be based on the holding period } \\
\text { of } 21 \text { days ago. }\end{array}$ \\
\hline LETF & $\begin{array}{l}\text { Leveraged Exchange-traded Funds (LETFs) are broadly defined as ETFs that track the return on an underlying index with a daily target multiple. The most popular } \\
\text { multiples are } 2 \times, 3 \times,-1 \times,-2 \times \text {, and }-3 \times \text {. }\end{array}$ \\
\hline ILETF family & $\begin{array}{l}\text { The series of international LETFs that track the same underlying foreign market index with various multiples such as } 2 \times, 3 \times,-1 \times,-2 \times \text {, and }-3 \times \text {. If available, we also } \\
\text { include the unlevered }(1 \mathrm{x}) \text { ETF as part of the family for comparison. }\end{array}$ \\
\hline Misperception-related Deviation & $\begin{array}{l}\text { Also referred to as misperception deviation. Return deviation component related to naïve investors' various misperceptions about an international LETF's target return. } \\
\text { It is calculated as the target return of an LETF less the Naïve Expected Return based on Foreign Index in foreign currency. We attribute this deviation component to the } \\
\text { currency deviation, discovery deviation and compounding deviation. }\end{array}$ \\
\hline Multiple & $\begin{array}{l}\text { Also called product multiple, leveraged multiple, target multiple, or daily target multiple. Reflects the LETF's daily target exposure to the benchmark. The multiple } \\
\text { can be positive (for bull LETFs) or negative (for bear/inverse LETFs). Examples include } 2 \times, 3 \times,-1 \times,-2 \times \text {, and }-3 \times \text {. }\end{array}$ \\
\hline Naïve expected return & $\begin{array}{l}\text { The return expected by a naïve investor. It is calculated as the product between the daily target multiple of an LETF and the cumulative return of the benchmark. This } \\
\text { naïve expected return differs from the target return for LETFs over multiple-day holding periods. }\end{array}$ \\
\hline $\begin{array}{l}\text { Naïve Expected Return Based on } \\
\text { Foreign Index }\end{array}$ & $\begin{array}{l}\text { Also referred to as Naïve expected return (index in Foreign currency). For daily observations, this variable equals the daily target multiple } \times \text { the underlying foreign } \\
\text { index return in foreign currency. For multiple holding days, this variable equals the daily target multiple } \times \text { cumulative return on the underlying foreign index in foreign } \\
\text { currency. }\end{array}$ \\
\hline $\begin{array}{l}\text { Naïve Expected Return Based on } \\
\text { Foreign Index in USD }\end{array}$ & $\begin{array}{l}\text { Also referred to as Naïve expected return (index in USD). For daily observations, this variable equals the daily target multiple } \times \text { the underlying foreign index return in } \\
\text { U.S. Dollar. For multiple holding days, this variable equals the daily target multiple } \times \text { cumulative return on the underlying foreign index converted to U.S. Dollar. }\end{array}$ \\
\hline \begin{tabular}{|l|} 
Naïve Expected Return Based on US- \\
traded Foreign Index Fund
\end{tabular} & $\begin{array}{l}\text { For daily observations, this variable equals the daily target multiple } \times \text { the daily return of the U.S.-traded unlevered ETF tracking the underlying foreign index. For } \\
\text { multiple holding days, this variable equals the daily target multiple } \times \text { cumulative return on the U.S.-traded unlevered ETF tracking the underlying foreign index. }\end{array}$ \\
\hline NAV & Net asset value of an LETF. \\
\hline NAV deviation & Also called NAV return deviation. It is computed as the NAV return of an LETF less its target return. \\
\hline NAV return & Return of an LETF based on percentage change in NAV, adjusted for dividend yield. \\
\hline Net fund flow & $\begin{array}{l}100 \text { times the change in shares outstanding from the the previous trading day, scaled by shares outstanding of the previous trading day. This measures the daily net fund } \\
\text { flows and excess demand from investors. }\end{array}$ \\
\hline Net fund flow of $(1 \times)$ fund & $\begin{array}{l}\text { Net fund flow of the }(1 \mathrm{x}) \text { regular ETF in an LETF family. } 100 \text { times the change in shares outstanding from the the previous trading day, scaled by shares outstanding of } \\
\text { the previous trading day. This measures the daily net fund flows and excess demand from investors. }\end{array}$ \\
\hline No overlapping indicator & $\begin{array}{l}\text { Equals } 1 \text { if the home country/region of the underlying index has no overlapping trading hours with those of United States. In our pooled sample, we include China, } \\
\text { Japan, Brazil, Mexico, and Europe. Out of these countries, China and Japan have no overlapping hours with the U. S. }\end{array}$ \\
\hline $\begin{array}{l}\text { Percent change in Hong Kong dollar } \\
\text { exchange rate }\end{array}$ & $\begin{array}{l}100 \text { times the change in Hong Kong dollar spot exchange rate (denoted as Hong Kong dollar per U.S. Dollar) from the the previous trading day, scaled by the Hong } \\
\text { Kong dollar spot exchange rate of the previous trading day. }\end{array}$ \\
\hline Relative bid-ask spread & 100 times the bid-ask spread over the midquote. \\
\hline SHCOMP index & Shanghai Stock Exchange Composite Index \\
\hline SHSZ300 index & $\begin{array}{l}\text { China CSI } 300 \text { Index is a capitalization-weighted stock market index designed to replicate the performance of } 300 \text { stocks traded in the Shanghai and Shenzhen stock } \\
\text { exchanges. }\end{array}$ \\
\hline SPX index & U.S. S\&P 500 Index \\
\hline $\begin{array}{l}\text { Square of cumulative }(1 \mathrm{x}) \text { fund return } \\
\text { during the holding period }\end{array}$ & The square of cumulative regular $(1 \mathrm{x})$ fund return during the holding period. \\
\hline Synchronous trading & A country has synchronous trading with U. S. if the major stock exchanges of two countries have at leas \\
\hline Target return & $\begin{array}{l}\text { Return target that an LETF is designed to achieve based on its product design. The daily target return equals the daily target multiple times the underlying benchmark } \\
\text { return. Based on the evidence from this paper, the international LETFs are benchmarked to the total daily return of the regular (1x) fund that tracks the same underlying } \\
\text { index. When the holding period is longer than one day, the target return of an LETF equals the daily LETF target return compounded over the holding period. }\end{array}$ \\
\hline Total deviation of LETF & $\begin{array}{l}\text { Also referred to as total return deviation of LETF. Actual Return of an LETF less naive expected return based on underlying index return in foreign currency if } \\
\text { available. When the naïve expected return in foreign currency is not available, this deviation is calculated as Actual Return of an LETF less naive expected return based } \\
\text { on underlying index return in USD. }\end{array}$ \\
\hline Total return of LETF & Also referred to as market return or total market return. Actual Return of an LETF calculated based on the actual market price (including dividends) of an LETF. \\
\hline Tracking-related Deviation & $\begin{array}{l}\text { Also referred to as Tracking-error deviation. Return deviation component related to the inability of the actual market return of an LETF to track its target return. It is } \\
\text { calculated as the actual market price return less the target return of an LETF. We attribute this deviation component to NAV deviation and inefficiency deviation. }\end{array}$ \\
\hline Turnover & Daily trading volume of an ETF over its shares outstanding. \\
\hline Underlying index return & $\begin{array}{l}\text { Also referred to as index return, equals total return (including price return and dividend yield) of an underlying benchmark index that an LETF is tracking. Whenever } \\
\text { available, this index is denoted in the home country currency. When the home country currency denoted index is not avialble, this index is denoted in the U.S. dollar. }\end{array}$ \\
\hline Underlying index return in USD & Total return (including price return and dividend yield) of an underlying benchmark index denoted in U. S. dollar that an LETF is tracking. \\
\hline Unlevered ETF & Regular $(1 \mathrm{x})$ ETF that tracks $100 \%$ of an underlying index. \\
\hline Valuation premium & The percentage difference between the market value of an ETF and its NAV. In particular, we use the equ \\
\hline $\begin{array}{l}\text { Variance of }(1 \mathrm{x}) \text { fund daily returns } \\
\text { during the holding period }\end{array}$ & The variance of daily returns of regular $(1 \mathrm{x})$ fund during the holding period. \\
\hline VIX & \\
\hline
\end{tabular}


Appendix Table B: The List of Regular and Leveraged International ETFs in the Sample

\begin{tabular}{|c|c|c|c|c|c|c|c|c|c|}
\hline ETF country & ETF Name & $\begin{array}{l}\text { ETF } \\
\text { Ticker }\end{array}$ & $\begin{array}{l}\text { Daily } \\
\text { Target }\end{array}$ & Underlying Index & $\begin{array}{c}\text { Index } \\
\text { Symbol * }\end{array}$ & $\begin{array}{c}\text { ETF } \\
\text { Inception }\end{array}$ & $\begin{array}{c}\text { ETF } \\
\text { Expense }\end{array}$ & $\begin{array}{l}\text { Assets Under } \\
\text { Management* }\end{array}$ & $\begin{array}{c}\text { Average Number } \\
\text { of Holding }\end{array}$ \\
\hline \multicolumn{10}{|c|}{ Panel A: ETFs for the countries without overlapping trading hours } \\
\hline China & $\underline{\text { Short FTSE China } 25}$ & $\underline{\text { YXI }}$ & $-1 \mathrm{x}$ & FTSE China 25 Index & XINOU & 3/16/2010 & 0.95 & 11.4 & 23.7 \\
\hline China & Ultra FTSE China 25 & $\underline{\mathrm{XPP}}$ & $2 \mathrm{x}$ & FTSE China 25 Index & XINOU & 6/2/2009 & 0.95 & 24.7 & 9.8 \\
\hline China & UltraShort FTSE China 25 & $\underline{\text { FXP }}$ & $-2 x$ & FTSE China 25 Index & XINOU & $11 / 6 / 2007$ & 0.95 & 204.7 & 1.1 \\
\hline China & iShares FTSE China 25 & $\underline{\text { FXI }}$ & $1 \mathrm{x}$ & FTSE China 25 Index & XINOU & $10 / 8 / 2004$ & 0.72 & 5255.4 & 7.3 \\
\hline Japan & $\underline{\text { Ultra MSCI Japan }}$ & $\underline{\mathrm{EZJ}}$ & $2 \mathrm{x}$ & MSCI Japan Index & MXJP & 6/2/2009 & 0.95 & 17.3 & 29.0 \\
\hline Japan & UltraShort MSCI Japan & $\underline{E W V}$ & $-2 \mathrm{x}$ & MSCI Japan Index & MXJP & $11 / 6 / 2007$ & 0.95 & 11.6 & 15.7 \\
\hline Japan & $\underline{\text { iShares MSCI Japan }}$ & EWJ & $1 \mathrm{x}$ & MSCI Japan Index & MXJP & 3/18/1996 & 0.51 & 4884.8 & 22.0 \\
\hline \multicolumn{10}{|c|}{ Panel B: ETFs for the countries/regions with overlapping trading hours } \\
\hline Brazil & $\underline{\text { Ultra MSCI Brazil }}$ & $\underline{\mathrm{UBR}}$ & $2 \mathrm{x}$ & MSCI Brazil Index & MXBR & 4/27/2010 & 0.95 & 8.9 & 15.9 \\
\hline Brazil & $\underline{\text { UltraShort MSCI Brazil }}$ & $\underline{B Z Q}$ & $-2 x$ & MSCI Brazil Index & MXBR & 6/16/2009 & 0.95 & 19.2 & 8.8 \\
\hline Brazil & $\underline{\text { iShares MSCI Brazil Index Fund }}$ & EWZ & $1 \mathrm{x}$ & MSCI Brazil Index & MXBR & $7 / 14 / 2000$ & 0.59 & 7195.3 & 7.6 \\
\hline Mexico & Ultra MSCI Mexico Investable Market & $\underline{\mathrm{UMX}}$ & $2 \mathrm{x}$ & MSCI Mexico Investable Market & MZMXI & 4/27/2010 & 0.95 & 1.5 & 76.3 \\
\hline Mexico & $\underline{\text { UltraShort MSCI Mexico Investable Market }}$ & $\underline{\mathrm{SMK}}$ & $-2 x$ & MSCI Mexico Investable Market & MZMXI & $6 / 16 / 2009$ & 0.95 & 2.3 & 27.3 \\
\hline Mexico & $\underline{\text { iShares MSCI Mexico Investable Market Index Fund }}$ & EWW & $1 \mathrm{x}$ & MSCI Mexico Investable Market & MZMXI & 3/18/1996 & 0.52 & 1011.7 & 6.3 \\
\hline Europe & Ultra MSCI Europe & $\underline{\mathrm{UPV}}$ & $2 \mathrm{x}$ & MSCI Europe Index & MXEU & 4/27/2010 & 0.95 & 2.1 & 18.5 \\
\hline Europe & UltraShort MSCI Europe & $\underline{\mathrm{EPV}}$ & $-2 x$ & MSCI Europe Index & MXEU & $6 / 16 / 2009$ & 0.95 & 264.8 & 11.0 \\
\hline Europe & Vanguard MSCI Europe & VGK & $1 \mathrm{x}$ & MSCI Europe Index & MXEU & 3/10/2005 & 0.16 & 1992.0 & 51.3 \\
\hline
\end{tabular}

Note: In the table above, the $(2 \mathrm{x})$ funds are bull LETFs. The $(-1 \mathrm{x})$ and $(-2 \mathrm{x})$ funds are bear/inverse LETFs. The $(1 \mathrm{x})$ fund is the regular, unlevered ETF for the purpose of comparison with the

LETFs. The sample periods for all funds in this study ends on May 31, 2012.

* Refers to the index symbol in Bloomberg.

** Refers to the Total Assets Under Management (in million USD) as of May 31, 2012

*** Refers to the Average Number of Holding Days during the Sample Period from the first date this LETF is available from Bloomberg to May 31, 2012. Calculated as the inverse of daily average ratio of volume over shares outstanding.

Source: Bloomberg. 
This table shows daily beta estimation results for the international LETFs by regressing the LETF daily returns on its underlying benchmark returns using the single-index model. The ending date for our sample is May 31, 2012. See Appendix A for variable definitions. Robust standard errors in parentheses; ${ }^{* * *} \mathrm{p}<1 \%,{ }^{* *} \mathrm{p}<5 \%,{ }^{*} \mathrm{p}<10 \%$ for the difference between the estimated beta and the LETF's target multiple.

Panel A: Daily beta of ETFs for countries without synchronized trading Underlying Index Country: China (FTSE China 25 Index)

Dep. Var. Daily market return of ETFs $\quad$ Daily market return of ETFs $\quad$ Daily NAV return of ETFs

\begin{tabular}{cccccccccc} 
Fund multiple & $(-2 \mathrm{x})$ & $(1 \mathrm{x})$ & $(2 \mathrm{x})$ & $(-2 \mathrm{x})$ & $(1 \mathrm{x})$ & $(2 \mathrm{x})$ & $(-2 \mathrm{x})$ & $(1 \mathrm{x})$ & $(2 \mathrm{x})$ \\
\hline & $(1)$ & $(2)$ & $(3)$ & $(4)$ & $(5)$ & $(6)$ & $(7)$ & $(8)$ & $(9)$
\end{tabular}

$\begin{array}{lllll}\text { Index daily return } & -1.142^{* * * *} & 0.601^{* * *} & 1.154^{* * *} & (4)\end{array}$

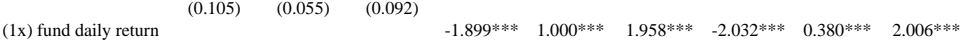

$\begin{array}{lccccccccc}\text { Constant } & -0.060 & 0.008 & 0.006 & -0.046^{*} & -0.000 & 0.007 & -0.019 & -0.016 & 0.008\end{array}$

$\begin{array}{lccccccccc} & (0.151) & (0.078) & (0.108) & (0.025) & (0.000) & (0.011) & (0.012) & (0.066) & (0.005)\end{array}$

$\begin{array}{llllllllll}\text { Observations } & 1,148 & 1,148 & 754 & 1,148 & 1,148 & 754 & 1,148 & 1,148 & 754\end{array}$

\begin{tabular}{lccccccccc} 
R-squared & 0.240 & 0.245 & 0.292 & 0.978 & 1.000 & 0.993 & 0.995 & 0.210 & 0.998 \\
F & 119.3 & 117.9 & 156.5 & 10109 &. & 26623 & 56907 & 77.28 & 320605 \\
\hline
\end{tabular}

Underlying Index Country: Japan (MSCI Japan Index)

Dep. Var. $\quad$ Daily market return of ETFs $\quad$ Daily market return of ETFs $\quad$ Daily NAV return of ETFs

\begin{tabular}{lccccccccc} 
Fund multiple & $(-2 \mathrm{x})$ & $(1 \mathrm{x})$ & $(2 \mathrm{x})$ & $(-2 \mathrm{x})$ & $(1 \mathrm{x})$ & $(2 \mathrm{x})$ & $(-2 \mathrm{x})$ & $(1 \mathrm{x})$ & $(2 \mathrm{x})$ \\
\hline & $(1)$ & $(2)$ & $(3)$ & $(4)$ & $(5)$ & $(6)$ & $(7)$ & $(8)$ & $(9)$
\end{tabular}

$\begin{array}{lccc}\text { Index daily return } \quad-0.626^{* * *} & 0.309^{* * * *} & 0.665^{* * *}\end{array}$

$\begin{array}{llllllllll}\text { (1x) fund daily return } & (0.102) & (0.057) & (0.118) & -1.869 * * * & 1.000 & 1.810 * * * & -2.036 * * * & 0.237 * * * & 2.024 * * *\end{array}$

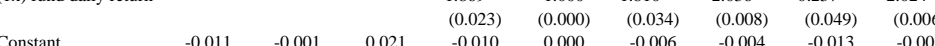

$\begin{array}{cccccccccc}(0.096) & (0.051) & (0.082) & (0.021) & (0.000) & (0.035) & (0.008) & (0.048) & (0.006)\end{array}$

\begin{tabular}{lccccccccc} 
R-squared & 37.50 & 29.88 & 32.01 & 6620 &. & 2880 & 70246 & 23.00 & 113100 \\
\hline
\end{tabular}

Panel B: Daily beta of ETFs for countries with synchronized trading

Underlying Index Country: Brazil (MSCI Brazil Index)

Dep. Var. Daily market return of ETFs Daily market return of ETFs Daily NAV return of ETFs

\begin{tabular}{|c|c|c|c|c|c|c|c|c|c|}
\hline & & & & & & & & & \\
\hline ultiple & $(-2 x)$ & (1x) & $(2 \mathrm{x})$ & $(-2 x)$ & (1x) & $(2 x)$ & $(-2 x)$ & (1x) & $(2 x)$ \\
\hline
\end{tabular}

$\begin{array}{llll}\text { Index daily return } & -1.876 * * * & 0.942^{* * *} & 1.837 * * *\end{array}$

(1x) fund daily retro

Constant

Observations

R-squared

$\begin{array}{lll}(0.040) \quad(0.020) \quad(0.059) & 0\end{array}$

\begin{tabular}{lllllllll}
2188 & 2169 & 961.5 & 6.989 & 1.000 & 0.968 & 0.999 & 0.908 & 0.999 \\
\hline
\end{tabular}

\begin{tabular}{|c|c|c|c|c|c|c|c|c|c|}
\hline \multirow{2}{*}{$\begin{array}{l}\text { Dep. Var. } \\
\text { Fund multiple } \\
\end{array}$} & \multicolumn{3}{|c|}{ Daily market return of ETFs } & \multicolumn{3}{|c|}{ Daily market return of ETFs } & \multicolumn{3}{|c|}{ Daily NAV return of ETFs } \\
\hline & $(-2 x)$ & $(1 \mathrm{x})$ & $(2 \mathrm{x})$ & $(-2 x)$ & $(1 \mathrm{x})$ & $(2 x)$ & $(-2 x)$ & $(1 \mathrm{x})$ & $(2 \mathrm{x})$ \\
\hline \multirow[b]{2}{*}{ Index daily return } & (1) & (2) & (3) & (4) & (5) & (6) & (7) & (8) & (9) \\
\hline & $\begin{array}{c}-1.748^{* * *} \\
(0.056)\end{array}$ & $\begin{array}{c}0.977^{* * *} \\
(0.023)\end{array}$ & $\begin{array}{c}1.119 * * * \\
(0.139)\end{array}$ & & & & & & \\
\hline (1x) fund daily return & & & & $\begin{array}{c}-1.694 * * * \\
(0.041)\end{array}$ & $\begin{array}{c}1.000^{* * * *} \\
(0.000)\end{array}$ & $\begin{array}{c}0.953 * * * \\
(0.130)\end{array}$ & $\begin{array}{c}-1.996 * * * \\
(0.003)\end{array}$ & $\begin{array}{c}0.799 * * * \\
(0.025)\end{array}$ & $\begin{array}{c}1.998^{* * *} \\
(0.002)\end{array}$ \\
\hline Constant & $\begin{array}{l}-0.062 \\
(0.068)\end{array}$ & $\begin{array}{c}0.012 \\
(0.028)\end{array}$ & $\begin{array}{c}0.044 \\
(0.133)\end{array}$ & $\begin{array}{l}-0.048 \\
(0.057)\end{array}$ & $\begin{array}{l}-0.000 \\
(0.000)\end{array}$ & $\begin{array}{c}0.036 \\
(0.136)\end{array}$ & $\begin{array}{c}-0.016 * * * \\
(0.006)\end{array}$ & $\begin{array}{c}0.013 \\
(0.025)\end{array}$ & $\begin{array}{l}-0.001 \\
(0.004)\end{array}$ \\
\hline Observations & 744 & 744 & 526 & 744 & 744 & 526 & 744 & 744 & 526 \\
\hline R-squared & 0.662 & 0.778 & 0.239 & 0.763 & 1.000 & 0.206 & 0.998 & 0.790 & 0.999 \\
\hline $\mathrm{F}$ & 968.8 & 1770 & 64.63 & 1671 & & 53.53 & 409515 & 1048 & 754429 \\
\hline \multicolumn{10}{|c|}{ Underlying Index Country: Europe (MSCI Europe Index) } \\
\hline \multirow{3}{*}{$\begin{array}{l}\text { Dep. Var. } \\
\text { Fund multiple } \\
\end{array}$} & \multicolumn{3}{|c|}{ Daily market return of ETFs } & \multicolumn{3}{|c|}{ Daily market return of ETFs } & \multicolumn{3}{|c|}{ Daily NAV return of ETFs } \\
\hline & $(-2 x)$ & (1x) & $(2 \mathrm{x})$ & $(-2 x)$ & (1x) & $(2 \mathrm{x})$ & $(-2 x)$ & $(1 \mathrm{x})$ & $(2 \mathrm{x})$ \\
\hline & (1) & (2) & (3) & (4) & (5) & (6) & (7) & (8) & (9) \\
\hline Index daily return & $\begin{array}{c}-2.268 * * * \\
(0.100)\end{array}$ & $\begin{array}{c}1.153 * * * \\
(0.051)\end{array}$ & $\begin{array}{c}2.227 * * * \\
(0.110)\end{array}$ & & & & & & \\
\hline (1x) fund daily return & & & & $\begin{array}{c}-1.943 * * * \\
(0.010)\end{array}$ & $\begin{array}{c}1.000 \\
(0.000)\end{array}$ & $\begin{array}{c}1.761 * * * \\
(0.032)\end{array}$ & $\begin{array}{c}-2.005 * * * \\
(0.003)\end{array}$ & $\begin{array}{c}0.876^{* * *} \\
(0.011)\end{array}$ & $\begin{array}{c}2.006 * * * \\
(0.003)\end{array}$ \\
\hline Constant & $\begin{array}{l}-0.001 \\
(0.090)\end{array}$ & $\begin{array}{c}-0.013 \\
(0.046)\end{array}$ & $\begin{array}{l}-0.015 \\
(0.108)\end{array}$ & $\begin{array}{c}-0.028 \\
(0.020)\end{array}$ & $\begin{array}{c}0.000 \\
(0.000)\end{array}$ & $\begin{array}{l}-0.010 \\
(0.059)\end{array}$ & $\begin{array}{c}-0.024 * * * \\
(0.004)\end{array}$ & $\begin{array}{c}0.003 \\
(0.026)\end{array}$ & $\begin{array}{c}0.000 \\
(0.005)\end{array}$ \\
\hline Observations & 744 & 744 & 526 & 744 & 744 & 526 & 744 & 744 & 526 \\
\hline R-squared & 0.569 & 0.568 & 0.575 & 0.978 & 1.000 & 0.874 & 0.999 & 0.848 & 0.999 \\
\hline $\mathrm{F}$ & 512.7 & 516.9 & 412.1 & 34336 & & 2942 & 431848 & 6556 & 353889 \\
\hline
\end{tabular}

Panel C: Daily beta of ETFs for pooled sample across countries

\begin{tabular}{|c|c|c|c|c|c|c|c|c|c|c|c|c|c|c|c|c|c|c|}
\hline \multirow[t]{2}{*}{ Dep. Var. } & \multicolumn{2}{|c|}{$\frac{\text { Market return of (- }}{2 \mathrm{x}) \text { fund }}$} & \multicolumn{2}{|c|}{$\frac{\text { Market return of }(2 x)}{\text { fund }}$} & \multicolumn{2}{|c|}{$\begin{array}{c}\text { Market return of }(1 \mathrm{x}) \\
\text { fund } \\
\end{array}$} & \multicolumn{2}{|c|}{$\frac{\text { NAV return of }(-2 x)}{\underline{\text { fund }}}$} & \multicolumn{2}{|c|}{$\frac{\text { NAV return of }(2 x)}{\text { fund }}$} & \multicolumn{2}{|c|}{$\frac{\text { NAV return of }(1 \mathrm{x})}{\text { fund }}$} & \multicolumn{2}{|c|}{$\frac{\text { Market return of }(-}{\underline{2 x) \text { fund }}}$} & \multicolumn{2}{|c|}{$\frac{\text { Market return of }(2 \mathrm{x})}{\text { fund }}$} & \multicolumn{2}{|c|}{$\frac{\text { Market return of }(1 \mathrm{x})}{\text { fund }}$} \\
\hline & (1) & (2) & (3) & (4) & (5) & (6) & (7) & (8) & (9) & (10) & (11) & (12) & (13) & (14) & (15) & (16) & (17) & $(18)$ \\
\hline Index daily return & $\begin{array}{c}-1.283 * * * \\
(0.057)\end{array}$ & $\begin{array}{c}-1.921^{* * *} \\
(0.034)\end{array}$ & $\begin{array}{c}1.369^{* * *} \\
(0.052)\end{array}$ & $\begin{array}{c}1.697 * * * \\
(0.060)\end{array}$ & $\begin{array}{c}0.667 * * * \\
(0.031)\end{array}$ & $\begin{array}{c}0.999 * * * \\
(0.016)\end{array}$ & & & & & & & & & & & & \\
\hline $\begin{array}{l}\text { Index daily return x } \\
\text { No-overlapping }\end{array}$ & & $\begin{array}{c}0.948 * * * \\
(0.088)\end{array}$ & & $\begin{array}{c}-0.716 * * * \\
(0.095)\end{array}$ & & $\begin{array}{c}-0.493 * * * \\
(0.047)\end{array}$ & & & & & & & & & & & & \\
\hline No overlapping indicat & & $\begin{array}{c}-0.018 \\
(0.100)\end{array}$ & & $\begin{array}{c}0.014 \\
(0.094)\end{array}$ & & $\begin{array}{c}0.006 \\
(0.052)\end{array}$ & & $\begin{array}{c}0.005 \\
(0.008)\end{array}$ & & $\begin{array}{c}0.004 \\
(0.005)\end{array}$ & & $\begin{array}{l}-0.018 \\
(0.043)\end{array}$ & & $\begin{array}{l}-0.004 \\
(0.027)\end{array}$ & & $\begin{array}{c}0.002 \\
(0.057)\end{array}$ & & $\begin{array}{c}0.000 \\
(0.000)\end{array}$ \\
\hline (1x) fund daily return & & & & & & & $\begin{array}{c}-2.022 * * * \\
(0.005)\end{array}$ & $\begin{array}{c}-2.001 * * * \\
(0.002)\end{array}$ & $\begin{array}{c}2.006 * * * \\
(0.002)\end{array}$ & $\begin{array}{c}2.002 * * * \\
(0.002)\end{array}$ & $\begin{array}{c}0.525^{* * *} \\
(0.026)\end{array}$ & $\begin{array}{c}0.879 * * * \\
(0.009)\end{array}$ & $\begin{array}{c}-1.890 * * * \\
(0.011)\end{array}$ & $\begin{array}{c}-1.887 * * * \\
(0.013)\end{array}$ & $\begin{array}{c}1.734 * * * \\
(0.026)\end{array}$ & $\begin{array}{c}1.618^{* * *} \\
(0.041)\end{array}$ & $\begin{array}{c}1.000 * * * \\
(0.000)\end{array}$ & $\begin{array}{c}1.000 * * * \\
(0.000)\end{array}$ \\
\hline $\begin{array}{l}\text { (1x) fund daily return } \\
\text { x No-overlapping }\end{array}$ & & & & & & & & $\begin{array}{c}-0.032 * * * \\
(0.007)\end{array}$ & & $\begin{array}{c}0.010^{* * *} \\
(0.004)\end{array}$ & & $\begin{array}{c}-0.536^{* * * *} \\
(0.036)\end{array}$ & & $\begin{array}{l}-0.004 \\
(0.020)\end{array}$ & & $\begin{array}{c}0.294^{* * *} \\
(0.043)\end{array}$ & & $\begin{array}{c}-0.000 * * * \\
(0.000)\end{array}$ \\
\hline Constant & $\begin{array}{c}-0.052 \\
(0.052)\end{array}$ & $\begin{array}{l}-0.024 \\
(0.043)\end{array}$ & $\begin{array}{c}0.011 \\
(0.048)\end{array}$ & $\begin{array}{c}0.004 \\
(0.065)\end{array}$ & $\begin{array}{c}0.014 \\
(0.027)\end{array}$ & $\begin{array}{c}0.001 \\
(0.021)\end{array}$ & $\begin{array}{c}-0.013 * * * \\
(0.004)\end{array}$ & $\begin{array}{c}-0.016 * * * \\
(0.003)\end{array}$ & $\begin{array}{l}-0.000 \\
(0.002)\end{array}$ & $\begin{array}{l}-0.002 \\
(0.003)\end{array}$ & $\begin{array}{c}0.004 \\
(0.023)\end{array}$ & $\begin{array}{c}0.004 \\
(0.014)\end{array}$ & $\begin{array}{l}-0.026^{*} \\
(0.013)\end{array}$ & $\begin{array}{l}-0.024 \\
(0.021)\end{array}$ & $\begin{array}{l}-0.000 \\
(0.029)\end{array}$ & $\begin{array}{l}-0.002 \\
(0.054)\end{array}$ & $\begin{array}{l}-0.000 \\
(0.000)\end{array}$ & $\begin{array}{l}-0.000 \\
(0.000)\end{array}$ \\
\hline Observations & 4,527 & 4,527 & 3,086 & 3,086 & 4,527 & 4,527 & 4,527 & 4,527 & 3,086 & 3,086 & 4,527 & 4,527 & 4,527 & 4,527 & 3,086 & 3,086 & 4,527 & 4,527 \\
\hline R-squared & 0.323 & 0.362 & 0.372 & 0.398 & 0.327 & 0.366 & 0.996 & 0.996 & 0.998 & 0.998 & 0.348 & 0.429 & 0.955 & 0.955 & 0.768 & 0.774 & 1.000 & 1.000 \\
\hline$F$ & 501.3 & 1097 & 688.2 & 326.2 & 476.7 & 1282 & 199699 & 455054 & $1.502 \mathrm{e}+06$ & 589127 & 396.4 & 2972 & 30222 & 12380 & 4577 & 7913 & & . \\
\hline
\end{tabular}

Panel D: Daily beta of ETFs for US and other regions 
Underlying Index Country: USA (SPX Index)

Dep. Var. Daily market return of ETFs $\quad$ Daily market return of ETFs $\quad$ Daily NAV return of ETFs

\begin{tabular}{llllllllll} 
Fund multiple & $(-2 \mathrm{x})$ & $(1 \mathrm{x})$ & $(2 \mathrm{x})$ & $(-2 \mathrm{x})$ & $(1 \mathrm{x})$ & $(2 \mathrm{x})$ & $(-2 \mathrm{x})$ & $(1 \mathrm{x})$ & $(2 \mathrm{x})$ \\
\hline & $(1)$ & $(2)$ & $(3)$ & $(4)$ & $(5)$ & $(6)$ & $(7)$ & $(8)$ & $(9)$
\end{tabular}

$\begin{array}{llll}\text { Index daily return } & -1.922 * * * & 0.987 * * * & 1.906 * *\end{array}$

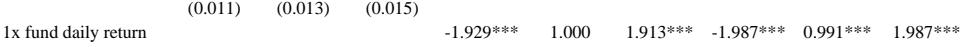

$\begin{array}{cccccccccc}\text { Constant } & 0.000 & -0.000 & -0.012 & (0.027) & (0.000) & (0.027) & (0.029) & (0.015) & (0.029) \\ & 0.011 & & 0.000 & -0.011 & 0.004 & 0.000 & -0.008\end{array}$

$\begin{array}{llllllllll} & (0.011) & (0.007) & (0.012) & (0.011) & (0.000) & (0.012) & (0.014) & (0.007) & (0.014)\end{array}$

$\begin{array}{llllllllll} & 1,156 & 1,156 & 1,156 & 1,156 & 1,156 & 1,156 & 1,156 & 1,156 & 1,156 \\ \text { R-squared } & 0.987 & 0.981 & 0.985 & 0.988 & 1.000 & 0.985 & 0.981 & 0.981 & 0.981 \\ & 29218 & 55 & 1632 & 5257 & & 5143 & 476 & \end{array}$

\begin{tabular}{llllllllll}
$\mathrm{F}$ & 29218 & 5517 & 16326 & 5257 &. & 5143 & 4707 & 4660 & 4664 \\
\hline
\end{tabular}

Underlying Index region: Pacific ex-Japan (MSCI Pacific ex-Japan Index)

Dep. Var $\quad$ Daily market return of ETFs Daily market return of ETFs Daily NAV return of ETFs

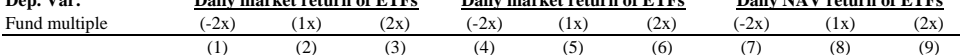

$\begin{array}{ccccccccc} & (1) & (2) & (3) & (4) & (5) & (6) & \text { (7) } & \text { (8) }\end{array}$

$\begin{array}{lll}(0.096) & (0.043) \quad(0.175)\end{array}$

1x fund daily return

$\begin{array}{lccccccccc} & & & & (0.061) & (0.000) & (0.145) & (0.003) & (0.033) & (0.003) \\ \text { Constant } & -0.046 & 0.015 & 0.021 & -0.038 & 0.000 & 0.025 & -0.008^{*} & 0.027 & -0.006\end{array}$

$\begin{array}{cccccccccc} & (0.105) & (0.051) & (0.160) & (0.080) & (0.000) & (0.137) & (0.004) & (0.042) & (0.005) \\ \text { Observations } & 741 & 741 & 527 & 741 & 741 & 527 & 741 & 741 & 527\end{array}$

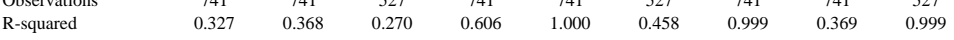

\begin{tabular}{llllllllll} 
F & 206.6 & 286.2 & 75.02 & 639.3 & . & 122.2 & 616275 & 226.6 & 470327 \\
\hline
\end{tabular}

Underlying Index region: Europe, Australasia and the Far East (MSCI EAFE Index)

Daily NAV returm of ETFs

\begin{tabular}{|c|c|c|c|}
\hline & & & \\
\hline und multiple & $(-2 x)$ & $(1 x)$ & $(28)$ \\
\hline
\end{tabular}

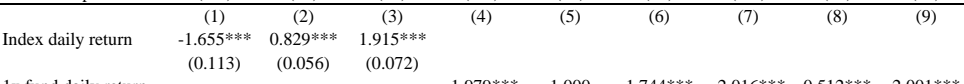

$\begin{array}{llllllll}1 \mathrm{x} \text { fund daily return } & -1.979 * * * & 1.000 & 1.744^{* * * *} & -2.016^{* * *} & 0.512^{* * * *} & 2.001^{* * *}\end{array}$

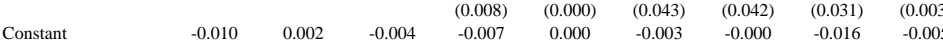

$\begin{array}{llllllllll} & (0.091) & (0.046) & (0.069) & (0.010) & (0.000) & (0.051) & (0.027) & (0.036) & (0.005)\end{array}$

$\begin{array}{llllllllll} & & \\ \text { Observations } & 1,156 & 1,156 & 754 & 1,156 & 1,156 & 754 & 1,156 & 1,156 & 754 \\ \text { R-squared } & 0.428 & 0.423 & 0.629 & 0.993 & 1,000 & 0.796 & 0.951 & 0.428 & 0.998\end{array}$

\begin{tabular}{lccccccccc} 
R-squared & 0.428 & 0.423 & 0.629 & 0.993 & 1.000 & 0.796 & 0.951 & 0.428 & 0.998 \\
F & 214.3 & 215.8 & 714.3 & 66204 &. & 1632 & 2298 & 264.0 & 450358 \\
\hline
\end{tabular}

Underlying Index region: Emerging Market (MSCI Emerging Markets Index)

Dep. Var. $\quad \underline{\text { Daily market return of ETFs }} \quad \underline{\text { Daily market return of ETFs }} \quad$ Daily NAV return of ETFs

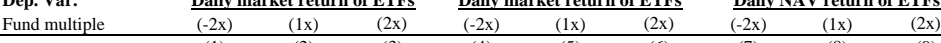

\begin{tabular}{lccccccccc}
\hline & $(1)$ & $(2)$ & $(3)$ & $(4)$ & $(5)$ & $(6)$ & $(7)$ & $(8)$ & $(9)$
\end{tabular}

$\begin{array}{lll}(0.139) \quad(0.079) \quad(0.099) & 0\end{array}$

$\begin{array}{lllllll}1 \mathrm{x} \text { fund daily return } & -1.897 * * * & 1.000 & 1.948^{* * *} & -2.014^{* * *} & 0.581^{* * *} & 1.990^{* * *}\end{array}$

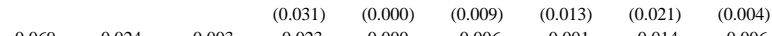

$\begin{array}{llllllllll} & -0.069 & 0.024 & -0.003 & -0.023 & 0.000 & -0.006 & -0.001 & -0.014 & -0.006\end{array}$

$\begin{array}{lccccccccc} & (0.121) & (0.065) & (0.091) & (0.023) & (0.000) & (0.014) & (0.014) & (0.031) & (0.005)\end{array}$

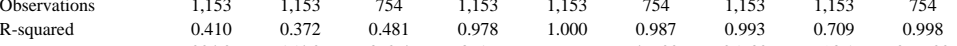

\begin{tabular}{lccccccccc} 
R-squared & 0.410 & 0.372 & 0.481 & 0.978 & 1.000 & 0.987 & 0.993 & 0.709 & 0.998 \\
$\mathrm{~F}$ & 204.2 & 154.0 & 372.4 & 3716 &. & 46700 & 25730 & 793.1 & 266722 \\
\hline
\end{tabular}




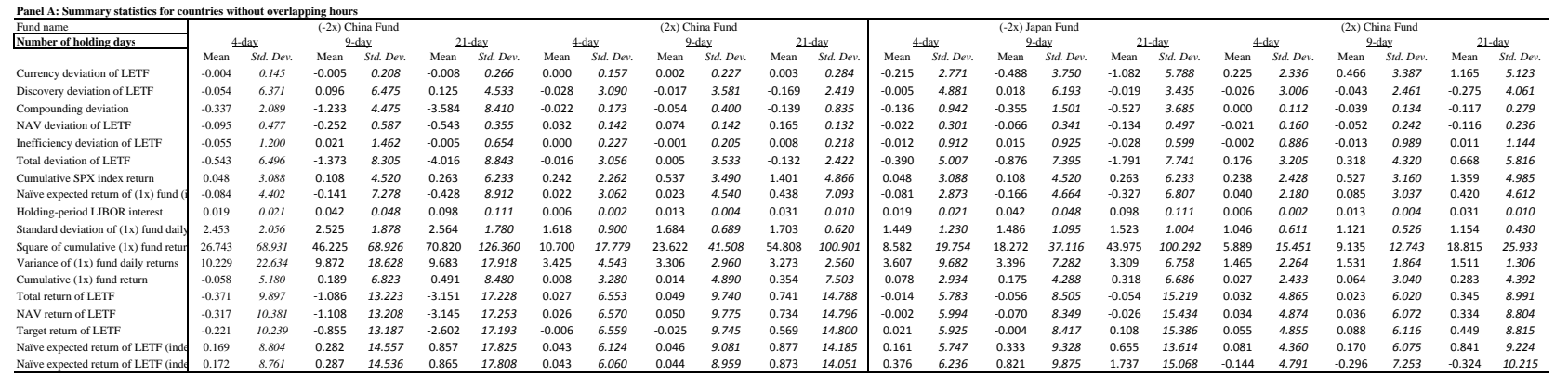

\begin{tabular}{|c|c|c|c|c|c|c|c|c|c|c|c|c|c|c|c|c|c|c|c|c|c|c|c|c|c|c|c|c|c|c|c|c|c|c|c|c|}
\hline \multirow{2}{*}{\begin{tabular}{|l|} 
Fund name \\
Number of holding days \\
\end{tabular}} & \multirow{2}{*}{\multicolumn{2}{|c|}{ 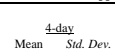 }} & \multicolumn{4}{|c|}{ 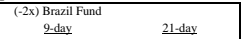 } & \multirow{2}{*}{\multicolumn{2}{|c|}{ Mean $\frac{4 \text { dav }}{S \text { std. Dev. }}$}} & \multicolumn{4}{|c|}{$\begin{array}{l}(2 x) \text { Brazil Fund } \\
\text { g-day }\end{array}$} & \multicolumn{2}{|c|}{ 4.day } & \multicolumn{2}{|c|}{$\begin{array}{l}(-2 x) \text { Mexico find } \\
\text { g-day }\end{array}$} & \multirow{2}{*}{\multicolumn{2}{|c|}{ Mean $\stackrel{21-\text { day }}{\text { Std. Dev. }}$}} & \multirow{2}{*}{\multicolumn{2}{|c|}{${ }_{\text {Mean }} \frac{4-\mathrm{day}}{\text { Std. Dev. }}$}} & \multicolumn{2}{|c|}{$\begin{array}{l}\text { (2x) Mexico Fund } \\
\text { g-day }\end{array}$} & \multirow{2}{*}{\multicolumn{2}{|c|}{ 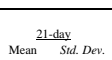 }} & \multirow{2}{*}{\multicolumn{2}{|c|}{${ }_{\operatorname{Mean}} \frac{4 \cdot \mathrm{dax}}{\text { Std. Dev. }}$}} & \multicolumn{4}{|c|}{$\begin{array}{l}(-2 x) \text { Europe Fund } \\
\text { g-day }\end{array}$} & \multicolumn{2}{|c|}{ 4davy } & \multicolumn{4}{|c|}{$\begin{array}{l}\text { (2x) Europe Fund } \\
\text { a.day }\end{array}$} \\
\hline & & & 0.000 & 000 & 100 & 000 & & & & $\begin{array}{l}\text { Sid. Dever. } \\
\text { 0.000 }\end{array}$ & & & & & & & & & & & $\begin{array}{c}\text { Mean } \\
0.0000\end{array}$ & & & & & & & & & & & & & & & \\
\hline & & 1.774 & -0.044 & 2.013 & 0.141 & 2.189 & & & 0.039 & 2.026 & & 1.588 & & 1.546 & $\begin{array}{l}-0.112 \\
-0.12\end{array}$ & 1.798 & -0.318 & 1.414 & 883 & & 172 & 1.158 & 0.424 & 1.572 & .003 & & $\begin{array}{l}0.0 .47 \\
0.051\end{array}$ & 34 & & & & & 0.026 & 33 & & 505 \\
\hline V deviation of LE & & $\begin{array}{l}0.588 \\
0160\end{array}$ & $\begin{array}{l}0.036 \\
0.068\end{array}$ & $\begin{array}{l}1.229 \\
0.133\end{array}$ & $\begin{array}{l}-0.480 \\
-0.161\end{array}$ & $\begin{array}{l}2.939 \\
0189\end{array}$ & & $\begin{array}{l}0.164 \\
0.084\end{array}$ & $\begin{array}{l}0.064 \\
0.00\end{array}$ & $\begin{array}{l}0.335 \\
0.19\end{array}$ & & $\begin{array}{l}0.557 \\
0.089\end{array}$ & 001 & 0.4 & & $\begin{array}{l}0.759 \\
0106\end{array}$ & 745 & $\begin{array}{l}1.367 \\
0.174\end{array}$ & 24 & . & 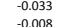 & $\begin{array}{l}0.226 \\
0.0228\end{array}$ & 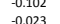 & $\begin{array}{l}0.492 \\
0.347\end{array}$ & 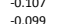 & & 422 & $\begin{array}{l}1.081 \\
01010\end{array}$ & 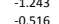 & 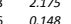 & 039 & & 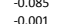 & 类 & $\begin{array}{l}-0.103 \\
-0.003\end{array}$ & 1.760 \\
\hline venatica & & $\begin{array}{l}0.160 \\
0.617\end{array}$ & $\begin{array}{l}-0.068 \\
0.035\end{array}$ & $\begin{array}{l}0.1133 \\
0.493\end{array}$ & $\begin{array}{l}-0.101 \\
0.064\end{array}$ & $\begin{array}{l}0.189 \\
0.449\end{array}$ & & 0.9 & & $\begin{array}{l}0.119 \\
0.477\end{array}$ & & 2.098 & 20 & 2.1 & & 123 & & 3.015 & & & 43 & $\begin{array}{l}0.228 \\
5.895\end{array}$ & 34 & 年 & 02 & & 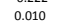 & & 111 & & & & 224 & 12 & .009 & 154 \\
\hline devia & & & $\begin{array}{l}-0.041 \\
-0.574\end{array}$ & 2.266 & & 3.661 & & 2.007 & & 2.008 & & 3.288 & & 2.3 & & 2.239 & & 3.3 & 53 & 5.3 & & & 65 & 4.409 & & & & & 227 & & & & (1) & 63 & .350 & .111 \\
\hline & & & & & & & & & & & & & & & & & & & & & & & & & & & & & & & & & & & & 320 \\
\hline & 5 & $\begin{array}{l}0.002 \\
0.02\end{array}$ & $\begin{array}{l}0.228 \\
0.013 \\
0\end{array}$ & $\begin{array}{l}5.6 .68 \\
0.004\end{array}$ & $\begin{array}{l}0.587 \\
0.031\end{array}$ & $\begin{array}{l}8.010 \\
0.010\end{array}$ & $\frac{11}{6}$ & $\begin{array}{l}3.502 \\
0.002\end{array}$ & & $\begin{array}{l}5.8 \\
0.0\end{array}$ & & 0.8 & 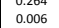 & 0.0 & 13 & & & & & & & & & & & & & & & & & & & & 然 & 009 \\
\hline & 1.690 & 0.948 & $1,1 / 2$ & 0.139 & 204 & 0.650 & & 0.5 & & 0.1 & & & & & & & & & & & & & & & & & & & & & & & & & 853 & 3 \\
\hline & & 20.302 & & & & & & & & & & & & & & & & & & & & & & & & & & & & & & & & & 503 & 3 \\
\hline & $\begin{array}{l}3.749 \\
0.115\end{array}$ & $\begin{array}{l}5.041 \\
3.776 \\
\end{array}$ & $\begin{array}{l}3.681 \\
0.250\end{array}$ & $\begin{array}{l}3.4 .40 \\
5.883\end{array}$ & 6 & $\begin{array}{l}2.827 \\
7.933\end{array}$ & 78 & $\begin{array}{l}4.8 .815 \\
3.598\end{array}$ & 3. & $\begin{array}{l}3.2 \\
5.9\end{array}$ & & $\begin{array}{l}2.935 \\
7.499\end{array}$ & & & & & & 5.6 & 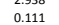 & & & & & & & & & & & & & & & & 068 & $\begin{array}{l}8 \\
2\end{array}$ \\
\hline & & & -0.496 & 11.901 & -1.5 & 15.838 & 13 & 7.337 & -0.652 & 11. & & 15.621 & 677 & 6.4 & 22 & & & & 193 & & & & 66 & & 444 & & & & & & & & & & .071 & 1 \\
\hline & & & & & & & & & & & & 15.033 & & 609 & & & & 10.575 & 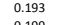 & & & & & & & & & & & & & & & & 0.038 & 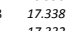 \\
\hline & & & 0.463 & $\begin{array}{l}11.932 \\
11.375\end{array}$ & $\begin{array}{l}-1.495 \\
-1.156\end{array}$ & $\begin{array}{l}16.061 \\
1.345 \\
1.45\end{array}$ & $\begin{array}{l}-0.038 \\
-0.282 \\
-x^{2}\end{array}$ & $\begin{array}{l}7.200 \\
7.070\end{array}$ & $\begin{array}{l}-0.624 \\
-0.0703 \\
-\end{array}$ & & & 13.033 & & $6.56 \mathrm{~s}$ & & & & 10.661 & .1999 & 5.856 & & & & & 0.347 & & & & & & & & & & $\begin{array}{l}0.041 \\
0.0699\end{array}$ & :332 \\
\hline & & 先.432 & & 111.375 & 1500 & & 0.282 & 7.070 & 0.703 & & & & & & & $\begin{array}{l}8.8000 \\
8.800\end{array}$ & & & .1.140 & 5.64. & & 9.07 & 0.600 & & & & & & 1.676 & & & & & 7.433 & 0.279 & 1.8.889 \\
\hline
\end{tabular}

